Prepared in cooperation with Llano Estacado Underground Water Conservation District, Sandy Land Underground Water Conservation District, and South Plains Underground Water Conservation District

Hydrogeologic Framework, Geochemistry, Groundwater-Flow System, and Aquifer Hydraulic Properties Used in the Development of a Conceptual Model of the Ogallala, Edwards-Trinity (High Plains), and Dockum Aquifers In and Near Gaines, Terry, and Yoakum Counties, Texas

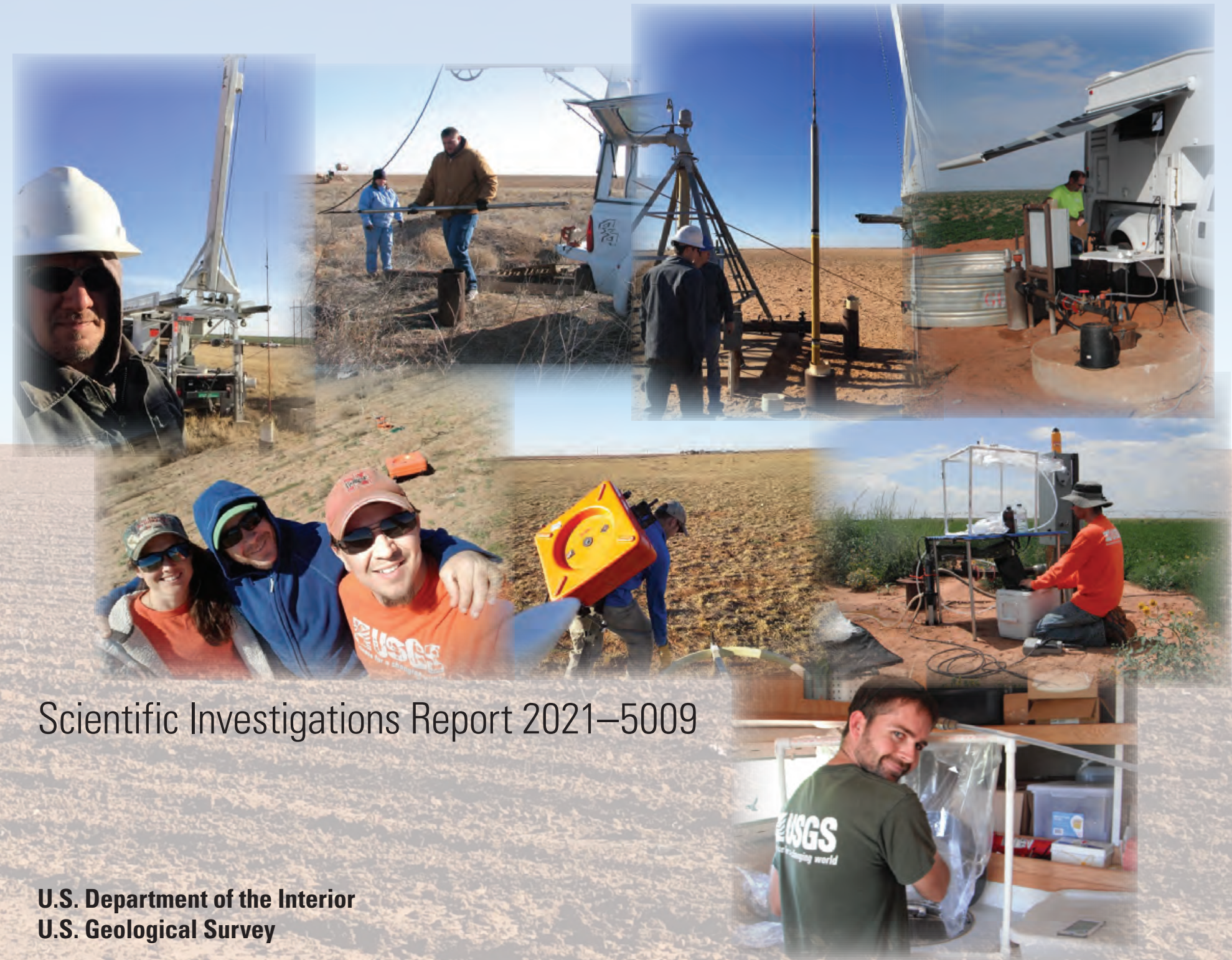




\section{Front cover:}

Background, Freshly plowed field in the study area in Gaines, Terry, and Yoakum Counties, Texas, March 2017. Photograph by Scott Ikard, U.S. Geological Survey.

(A) U.S. Geological Survey scientist making a borehole nuclear magnetic resonance measurement in the study area in Gaines, Terry, and Yoakum Counties, Texas, April 2018. Photograph by Kurt Kraske, U.S. Geological Survey.

(B) U.S. Geological Survey scientists preparing the borehole caliper tool for data collection in the study area in Gaines, Terry, and Yoakum Counties, Texas, February 2014. Photograph by Andrew Teeple, U.S. Geological Survey.

(C) U.S. Geological Survey scientists preparing the borehole nuclear magnetic resonance tool for data collection in the study area in Gaines, Terry, and Yoakum Counties, Texas, April 2018. Photograph by Kurt Kraske, U.S. Geological Survey.

(D) U.S. Geological Survey scientist assessing the physical properties of water before sample collection from a groundwater well in the study area in Gaines, Terry, and Yoakum Counties, Texas, August 2014. Photograph by Scott Ikard, U.S. Geological Survey.

(E) U.S. Geological Survey scientists after collecting the last time-domain electromagnetic sounding for the trip in the study area in Gaines, Terry, and Yoakum Counties, Texas, March 2017. Photograph by Andrew Teeple, U.S. Geological Survey.

(F) U.S. Geological Survey scientist setting up the receiver antenna for a time-domain electromagnetic sounding in the study area in Gaines, Terry, and Yoakum Counties, Texas, March 2014. Photograph by Natalie Houston, U.S. Geological Survey.

(G) U.S. Geological Survey scientist assessing the physical properties of water before sample collection from a groundwater well in the study area in Gaines, Terry, and Yoakum Counties, Texas, July 2016. Photograph by Chiquita Lopez, U.S. Geological Survey.

(H) U.S. Geological Survey scientist collecting water-quality samples in the study area in Gaines, Terry, and Yoakum Counties, Texas, July 2016.

Photograph by Chiquita Lopez, U.S. Geological Survey.

\section{Back cover:}

Background, U.S. Geological Survey scientist and field support dog collecting a time-domain electromagnetic sounding in the study area in Gaines, Terry, and Yoakum Counties, Texas, February 2017. Photograph by Scott Ikard, U.S. Geological Survey.

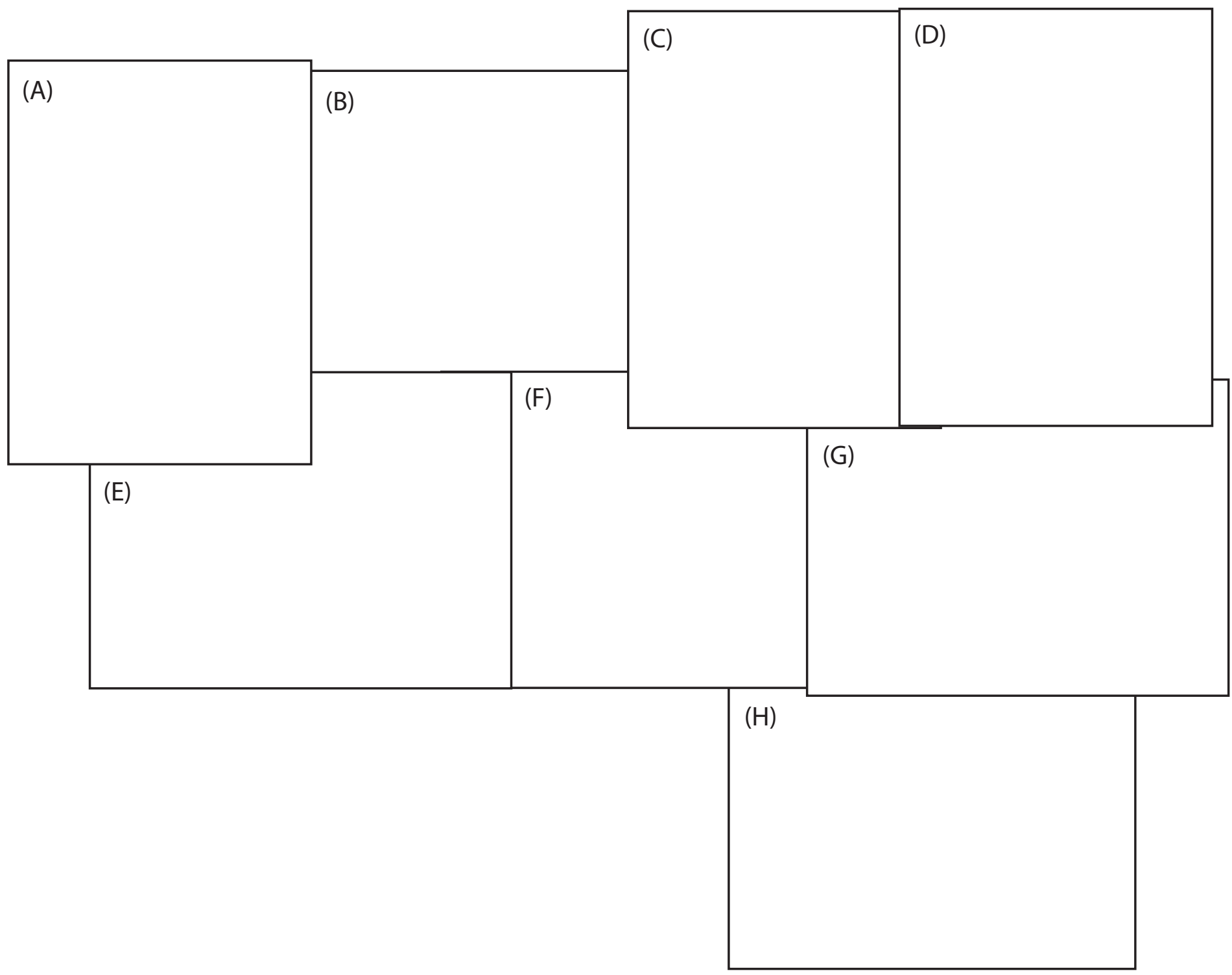




\section{Hydrogeologic Framework, Geochemistry, Groundwater-Flow System, and Aquifer Hydraulic Properties Used in the Development of a Conceptual Model of the Ogallala, Edwards-Trinity (High Plains), and Dockum Aquifers In and Near Gaines, Terry, and Yoakum Counties, Texas}

By Andrew P. Teeple, Patricia B. Ging, Jonathan V. Thomas, David S. Wallace, and Jason D. Payne

Prepared in cooperation with Llano Estacado Underground Water Conservation District, Sandy Land Underground Water Conservation District, and South Plains Underground Water Conservation District

Scientific Investigations Report 2021-5009 


\section{U.S. Geological Survey, Reston, Virginia: 2021}

For more information on the USGS - the Federal source for science about the Earth, its natural and living resources, natural hazards, and the environment—visit https://www.usgs.gov or call 1-888-ASK-USGS.

For an overview of USGS information products, including maps, imagery, and publications, visit https://store.usgs.gov/.

Any use of trade, firm, or product names is for descriptive purposes only and does not imply endorsement by the U.S. Government.

Although this information product, for the most part, is in the public domain, it also may contain copyrighted materials as noted in the text. Permission to reproduce copyrighted items must be secured from the copyright owner.

Suggested citation:

Teeple, A.P., Ging, P.B., Thomas, J.V., Wallace, D.S., and Payne, J.D., 2021, Hydrogeologic framework, geochemistry, groundwater-flow system, and aquifer hydraulic properties used in the development of a conceptual model of the Ogallala, Edwards-Trinity (High Plains), and Dockum aquifers in and near Gaines, Terry, and Yoakum Counties, Texas: U.S. Geological Survey Scientific Investigations Report 2021-5009, 68 p., https://doi.org/10.3133/sir20215009.

Associated data for this publication:

Payne, J.D., Teeple, A.P., and Thomas, J.V., 2020, Compilation of time-domain electromagnetic surface geophysical soundings, historical borehole characteristics, water level, water quality and hydraulic properties data throughout Gaines, Yoakum, and Terry Counties in Texas, 1929-2019: U.S. Geological Survey data release, https://doi.org/ 10.5066/P9N3WK05.

ISSN 2328-031X (print) ISSN 2328-0328 (online) 


\section{Acknowledgments}

The authors thank the district managers, Lori Barnes of Llano Estacado Underground Water Conservation District, Amber Blount of Sandy Land Underground Water Conservation District, and Lindy Harris of South Plains Underground Water Conservation District. The district managers provided support in early project data compilation, orchestrated land-owner permissions and property access for data collection efforts, and helped with other aspects of the project. Thanks go to Layne Marlow of South Plains Underground Water Conservation District for logistical and field assistance and to Don Harridge of Llano Estacado Underground Water Conservation District for expediting the field collection efforts. Technical assistance from Ray Brady and Amy Bush of RMBJ Geo, Inc., who shared their knowledge of the geology and hydrology of the study area, is appreciated.

The authors also thank Natalie Houston, Scott Ikard, Kurt Kraske, Jeremy McDowell, Kelvey Merrill, and George Umphres of the U.S. Geological Survey for assisting in collection of the geophysical data. Assistance with groundwater geochemical data collection was provided by Cassi Crow, Becky Lambert, Chiquita Lopez, Keith Mecum, Mike Nyman, and Aaron Pugh of the U.S. Geological Survey. 



\section{Contents}

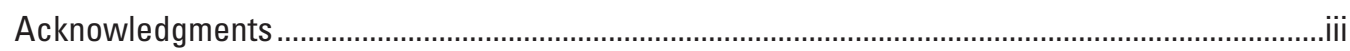

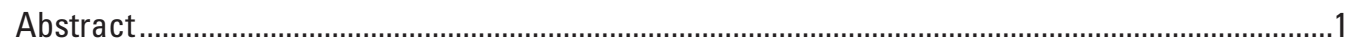

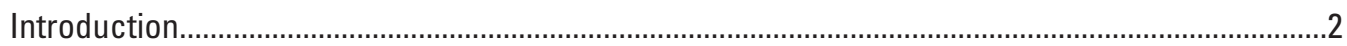

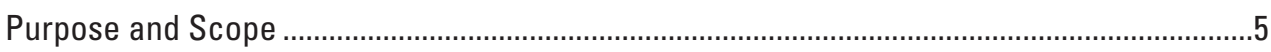

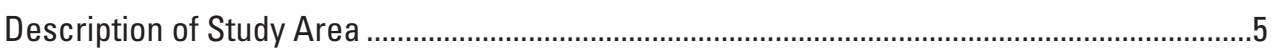

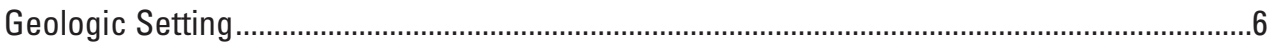

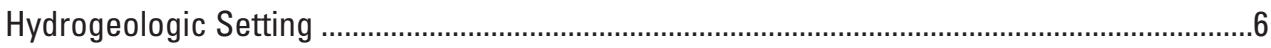

Synopsis of Previous Studies for This Multiphase Project.........................................................

Development of a Refined Hydrogeologic Framework ....................................................................

Data Compilation and Collection ..................................................................................

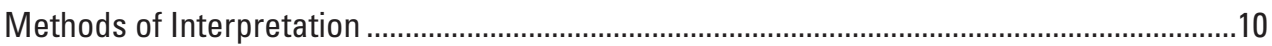

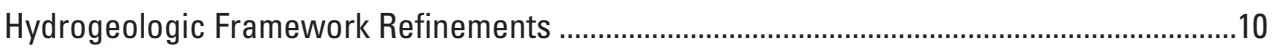

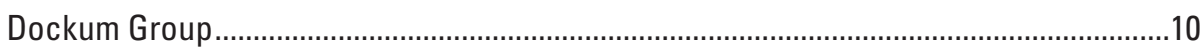

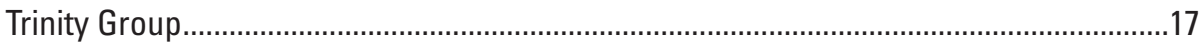

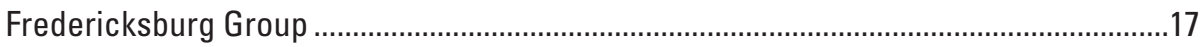

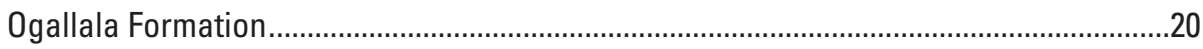

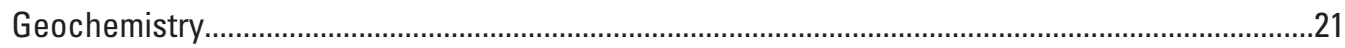

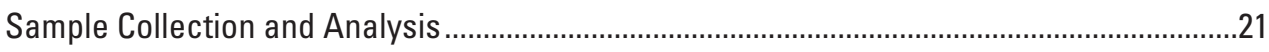

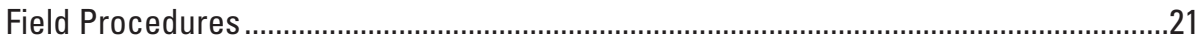

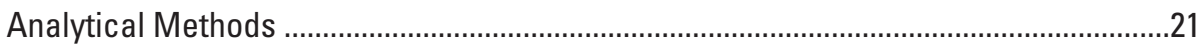

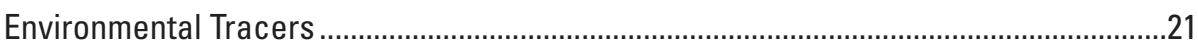

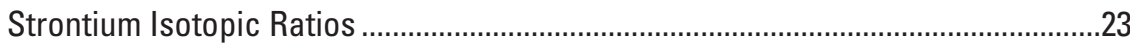

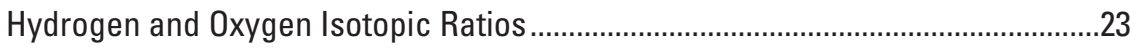

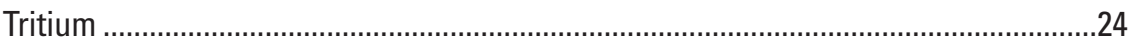

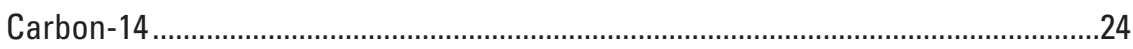

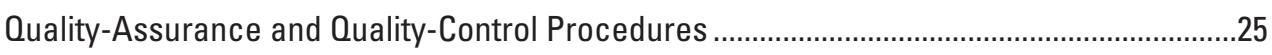

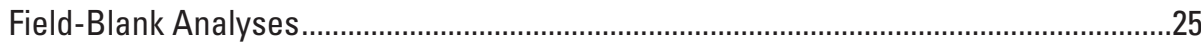

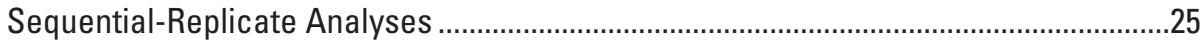

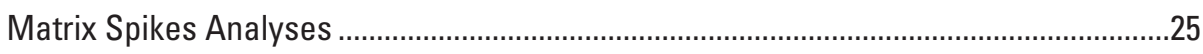

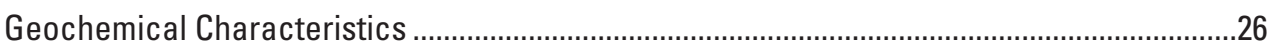

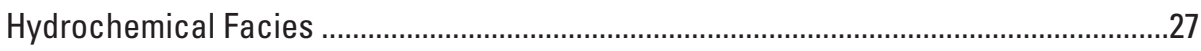

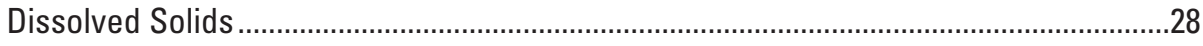

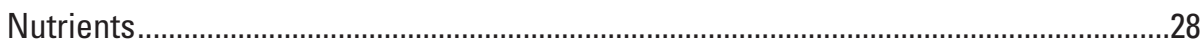

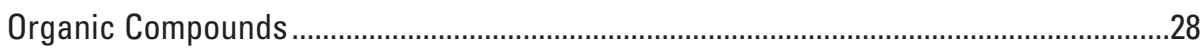

Environmental Tracers ........................................................................................

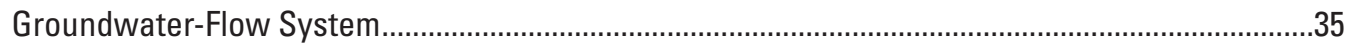

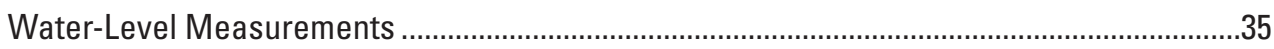

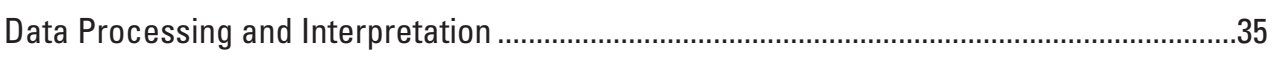

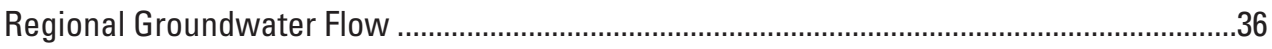

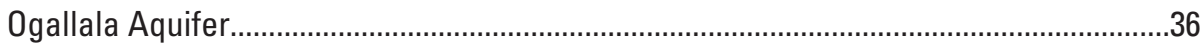

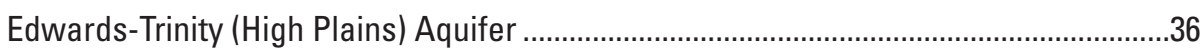

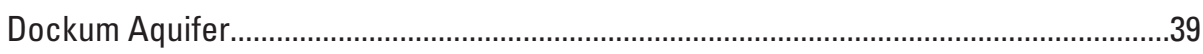




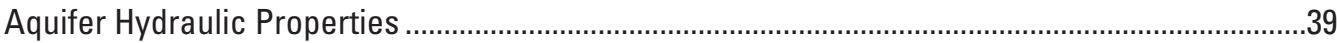

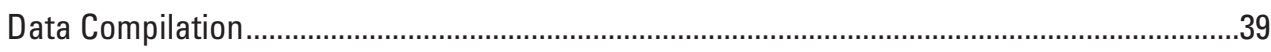

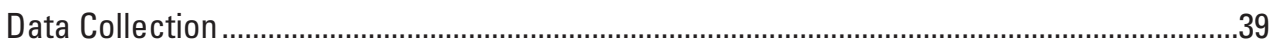

Borehole Electromagnetic Flowmeter …………………...........................................41

Borehole Nuclear Magnetic Resonance Sounding ......................................................42

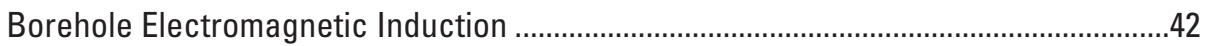

Methods

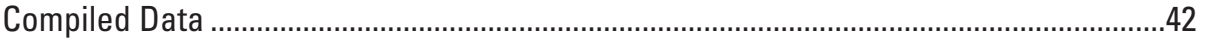

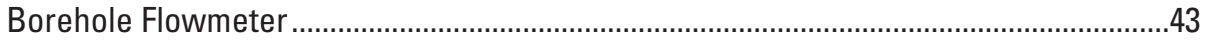

Borehole Nuclear Magnetic Resonance ........................................................................43

Time-Domain Electromagnetic Soundings ……………................................................4

Resistivity and Total Porosity Regression Equation ................................................4

Effective Porosity and Total Porosity Regression.......................................................44

Application of Regression Equations to the Time-Domain Electromagnetic

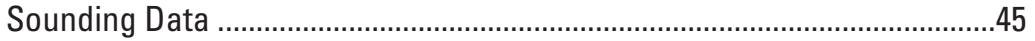

Hydraulic Conductivity, Specific Yield, and Specific Yield Variability......................................4

Ogallala Aquifer........................................................................................................

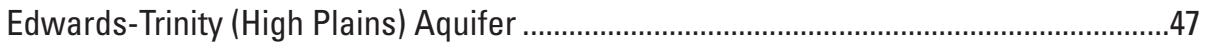

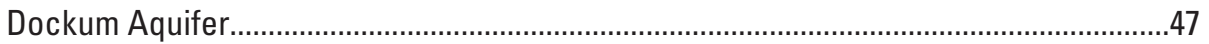

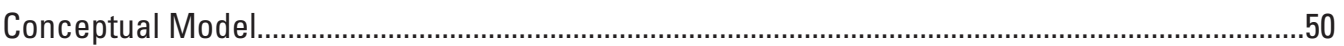

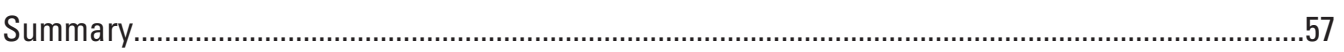

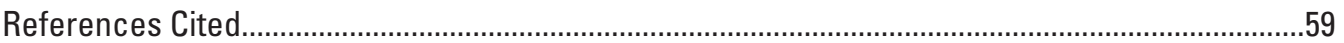

\section{Figures}

1. Map of study area location in Gaines, Terry, and Yoakum Counties, Texas, within the regional extent of the major aquifers and physiographic provinces pertaining to this assessment

2. Map of hydrogeologic data sites, land-surface altitude, downdip extent of the Edwards-Trinity (High Plains) aquifer system, and study area extent

3. Map of National Land Cover Database 2011 land-cover categories and locations of wells from which samples for water-quality data were collected in Gaines, Terry, and Yoakum Counties, Texas, 2014 and 2016

4. Chart of geologic and hydrogeologic units and lithologic descriptions in and near Gaines, Terry, and Yoakum Counties, Texas

5. Maps of revised (2020) hydrogeologic unit surfaces for the base (bottom) of the Dockum Group, the base of the Trinity Group, the base of the Fredericksburg Group, and the base of the Ogallala Formation in and near Gaines, Terry, and Yoakum Counties, Texas

6. Maps of differences in mapped altitudes between the hydrogeologic unit surfaces and the newly (2020) developed hydrogeologic unit surfaces for the base (bottom) of the Dockum Group, the base of the Trinity Group, the base of the Fredericksburg Group, and the base of the Ogallala Formation in and near Gaines, Terry, and Yoakum Counties, Texas 
7. Maps of results of trend-removal grids and hydrology toolset analysis used to identify paleochannel locations in the hydrogeologic unit surfaces for the base (bottom) of the Trinity Group, the base of the Fredericksburg Group, and the base of the Ogallala Formation in and near Gaines, Terry, and Yoakum Counties, Texas

8. Maps of hydrogeologic unit thickness of the Dockum Group, the Trinity Group, the Fredericksburg Group, and the Ogallala Formation in and near Gaines, Terry, and Yoakum Counties, Texas

9. Diagram of relations between major cations and anions measured in water-quality samples from groundwater wells in Gaines, Terry, and Yoakum Counties, Texas, 2014 and 2016

10. Map of dissolved-solids concentrations in groundwater wells sampled in Gaines, Terry, and Yoakum Counties, Texas, 2014 and 2016.

11. Map of nitrate plus nitrite concentrations in water-quality samples from groundwater wells in Gaines, Terry, and Yoakum Counties, Texas, 2014 and 2016

12. Graph of relation between dissolved-solids and nitrate plus nitrite concentrations in water-quality samples from groundwater wells in Gaines, Terry, and Yoakum Counties, Texas, 2014 and 2016

13. Maps of metolachlor concentrations detected in water-quality samples from groundwater wells in Gaines, Terry, and Yoakum Counties, Texas, for 2014 and 2016 and for 2000-03

14. Maps of deethylatrazine concentrations detected in water-quality samples from groundwater wells in Gaines, Terry, and Yoakum Counties, Texas, for 2014 and 2016 and for 2000-03

15. Boxplot of strontium isotopic values in water-quality samples from groundwater wells in Gaines, Terry, and Yoakum Counties, Texas, 2014 and 2016

16. Graph of relation between stable isotopes of hydrogen and oxygen in water-quality samples from groundwater wells in Gaines, Terry, and Yoakum Counties, Texas, 2014 and 2016

17. Graph of tritium and carbon-14 concentrations in water-quality samples from groundwater wells in Gaines, Terry, and Yoakum Counties, Texas, 2014 and 2016 .........36

18. Map of relative ages of groundwater in Gaines, Terry, and Yoakum Counties, Texas, 2014 and 2016

19. Maps of potentiometric surfaces developed from groundwater-level altitudes measured during the dormant season in wells completed in the Ogallala aquifer, the Edwards-Trinity (High Plains) aquifer system, and the Dockum aquifer in and near Gaines, Terry, and Yoakum Counties, Texas

20. Graph of relation between the borehole nuclear magnetic resonance total porosity and the formation factor computed from the borehole electromagnetic induction and fluid conductivity logs for wells in Gaines, Terry, and Yoakum Counties, Texas, 2012-18

21. Graph of relation between the borehole nuclear magnetic resonance total porosity and the estimated total porosity from the formation factor computed from the borehole electromagnetic induction and fluid conductivity logs for wells in Gaines, Terry, and Yoakum Counties, Texas, 2012-18

22. Graph of relation between the borehole nuclear magnetic resonance total porosity and fluid fraction of the total porosity for wells in Gaines, Terry, and Yoakum Counties, Texas, 2012-18 
23. Graph of relation between the absolute difference of the mobile-water fraction of the borehole nuclear magnetic resonance total porosity with the estimated effective porosity and the formation factor for wells in Gaines, Terry, and Yoakum Counties, Texas, 2012-18

24. Maps of hydraulic-conductivity values computed from historical aquifer test, borehole electromagnetic flowmeter, and borehole nuclear magnetic resonance data for the Ogallala aquifer, the Edwards-Trinity (High Plains) aquifer system, and the Dockum aquifer

25. Maps of estimated specific yield and specific yield variability values computed from borehole nuclear magnetic resonance and inverse modeling results of the time-domain electromagnetic data for the Ogallala aquifer, the Edwards-Trinity (High Plains) aquifer system, and the Dockum aquifer

26. Map of combined hydrogeologic unit thickness of the Trinity and Fredericksburg Groups and Ogallala Formation in and near Gaines, Terry, and Yoakum Counties, Texas.

27. Map of groundwater groups for the water-quality samples collected in Gaines, Terry, and Yoakum Counties, Texas, 2014 and 2016

28. Maps of saturated thickness of the Ogallala aquifer and the combined Ogallala aquifer and the Edwards-Trinity (High Plains) aquifer system in and near Gaines, Terry, and Yoakum Counties, Texas

\section{Tables}

1. Descriptive statistics for the primary geologic units for each conservation district in the study area in and near Gaines, Terry, and Yoakum Counties, Texas

2. Selected well completion information, aquifer designation, and sampling date for groundwater-quality samples collected from wells in and near Gaines, Terry, and Yoakum Counties, Texas

3. U.S. Environmental Protection Agency primary and secondary drinking water standards, U.S. Geological Survey health-based screening levels, and the percent of samples that exceeded the designated standard or level for selected constituents analyzed in groundwater samples in Gaines, Terry, and Yoakum Counties, Texas, 2014 and 2016

4. Selected well completion information, aquifer designation, borehole geophysical method, and measurement date for borehole geophysical data collected from wells in and near Gaines, Terry, and Yoakum Counties, Texas

5. Description of groundwater groups and median water-quality results for groundwater groups from water-quality samples collected in Gaines, Terry, and Yoakum Counties, 2014 and 2016

6. Estimated groundwater storage volumes computed from the estimated saturated thickness and estimated specific yield and specific yield variability values computed from borehole nuclear magnetic resonance and inverse modeling results of the time-domain electromagnetic data for the High Plains aquifer system (Ogallala aquifer), Edwards-Trinity (High Plains) aquifer system, and the combined Ogallala aquifer and Edwards-Trinity (High Plains) aquifer systems in and near Gaines, Terry, and Yoakum Counties, Texas. 


\section{Conversion Factors}

U.S. customary units to International System of Units

\begin{tabular}{|c|c|c|}
\hline Multiply & By & To obtain \\
\hline \multicolumn{3}{|c|}{ Length } \\
\hline inch (in.) & 2.54 & centimeter $(\mathrm{cm})$ \\
\hline inch (in.) & 25.4 & millimeter $(\mathrm{mm})$ \\
\hline foot $(\mathrm{ft})$ & 0.3048 & meter $(\mathrm{m})$ \\
\hline mile (mi) & 1.609 & kilometer $(\mathrm{km})$ \\
\hline \multicolumn{3}{|c|}{ Area } \\
\hline square mile $\left(\mathrm{mi}^{2}\right)$ & 259.0 & hectare (ha) \\
\hline square mile $\left(\mathrm{mi}^{2}\right)$ & 2.590 & square kilometer $\left(\mathrm{km}^{2}\right)$ \\
\hline \multicolumn{3}{|c|}{ Volume } \\
\hline ounce, fluid (fl. oz) & 0.02957 & liter (L) \\
\hline pint (pt) & 0.4732 & liter $(\mathrm{L})$ \\
\hline quart (qt) & 0.9464 & liter $(\mathrm{L})$ \\
\hline gallon (gal) & 3.785 & liter $(\mathrm{L})$ \\
\hline gallon (gal) & 0.003785 & cubic meter $\left(\mathrm{m}^{3}\right)$ \\
\hline gallon (gal) & 3.785 & cubic decimeter $\left(\mathrm{dm}^{3}\right)$ \\
\hline cubic inch $\left(\mathrm{in}^{3}\right)$ & 0.01639 & liter (L) \\
\hline acre-foot (acre-ft) & 1,233 & cubic meter $\left(\mathrm{m}^{3}\right)$ \\
\hline acre-foot (acre-ft) & 0.001233 & cubic hectometer $\left(\mathrm{hm}^{3}\right)$ \\
\hline \multicolumn{3}{|c|}{ Flow rate } \\
\hline gallon per minute (gal/min) & 0.06309 & liter per second (L/s) \\
\hline \multicolumn{3}{|c|}{ Radioactivity } \\
\hline picocurie per liter $(\mathrm{pCi} / \mathrm{L})$ & 0.037 & becquerel per liter $(\mathrm{Bq} / \mathrm{L})$ \\
\hline \multicolumn{3}{|c|}{ Hydraulic conductivity } \\
\hline foot per day (ft/d) & 0.3048 & meter per day $(\mathrm{m} / \mathrm{d})$ \\
\hline
\end{tabular}

Temperature in degrees Fahrenheit $\left({ }^{\circ} \mathrm{F}\right)$ may be converted to degrees Celsius $\left({ }^{\circ} \mathrm{C}\right)$ as follows: ${ }^{\circ} \mathrm{C}=\left({ }^{\circ} \mathrm{F}-32\right) / 1.8$.

\section{Datum}

Vertical coordinate information is referenced to the North American Vertical Datum of 1988 (NAVD 88).

Horizontal coordinate information is referenced to the North American Datum of 1983 (NAD 83).

Altitude, as used in this report, refers to distance above the vertical datum. 


\section{Supplemental Information}

Specific conductance is given in microsiemens per centimeter at 25 degrees Celsius $(\mu \mathrm{S} / \mathrm{cm})$.

Concentrations of chemical constituents in water are given in milligrams per liter $(\mathrm{mg} / \mathrm{L})$, micrograms per liter $(\mu \mathrm{g} / \mathrm{L})$, or milliequivalents per liter.

Milligrams per liter are units expressing the mass of the solute per unit volume (liter) of water; milligrams per liter is equivalent to parts per million. Micrograms per liter are units expressing the mass of the solute per unit volume (liter) of water; micrograms per liter is equivalent to parts per billion. Milliequivalents are units expressing the number of electron-millimoles of a solute per unit volume (liter). Milliequivalents per liter is a unit expressing the concentration of chemical constituents in solution as $1 / 1000$ the molecular weight, in milligrams, divided by the valence of one molecule of the constituent per unit volume (liter) of water.

Activities for radioactive constituents in water are given in picocuries per liter ( $\mathrm{pCi} / \mathrm{L}$ ).

Tritium concentrations are discussed in tritium units (TU). Based upon a tritium half-life of 12.32 years (Lucas and Unterweger, 2000), 1 TU is equal to 3.22 picocuries per liter (pCi/L).

Resistivity is given in ohm-meters (ohm-m).

\section{Isotope Unit Explanation}

Per mil: A unit commonly used to express the ratio of stable isotope abundance of an element in a sample to the abundance of the same element in a standard material. Per mil units are equivalent to parts per thousand. Stable isotope ratios are computed as follows (Kendall and McDonnell, 1998):

$\delta \mathrm{X}=\left\{\left(\mathrm{R}_{\text {sample }}-\mathrm{R}_{\text {standard }}\right) / \mathrm{R}_{\text {standard }}\right\} \times 1,000$

where

$\delta \quad$ is the "delta" notation,

$\mathrm{X}$ is the heavier stable isotope, and

$\mathrm{R}$ is the ratio of the heavier, less abundant isotope to the lighter, stable isotope in a sample or standard.

The $\delta$ values for stable isotope ratios discussed in this report are referenced to the following standard materials:

\begin{tabular}{rcc}
\hline Element & R & \multicolumn{1}{c}{ Standard identity and reference } \\
\hline Hydrogen & Hydrogen-2/hydrogen-1 $(\delta \mathrm{D})$ & $\begin{array}{c}\text { Vienna Standard Mean Ocean Water (Fritz and Fontes, } \\
\text { 1980) }\end{array}$ \\
Oxygen & Oxygen-18/oxygen-16 $\left(\delta^{18 \mathrm{O})}\right.$ & $\begin{array}{c}\text { Vienna Standard Mean Ocean Water (Fritz and Fontes, } \\
1980)\end{array}$ \\
\hline
\end{tabular}




\section{Abbreviations}

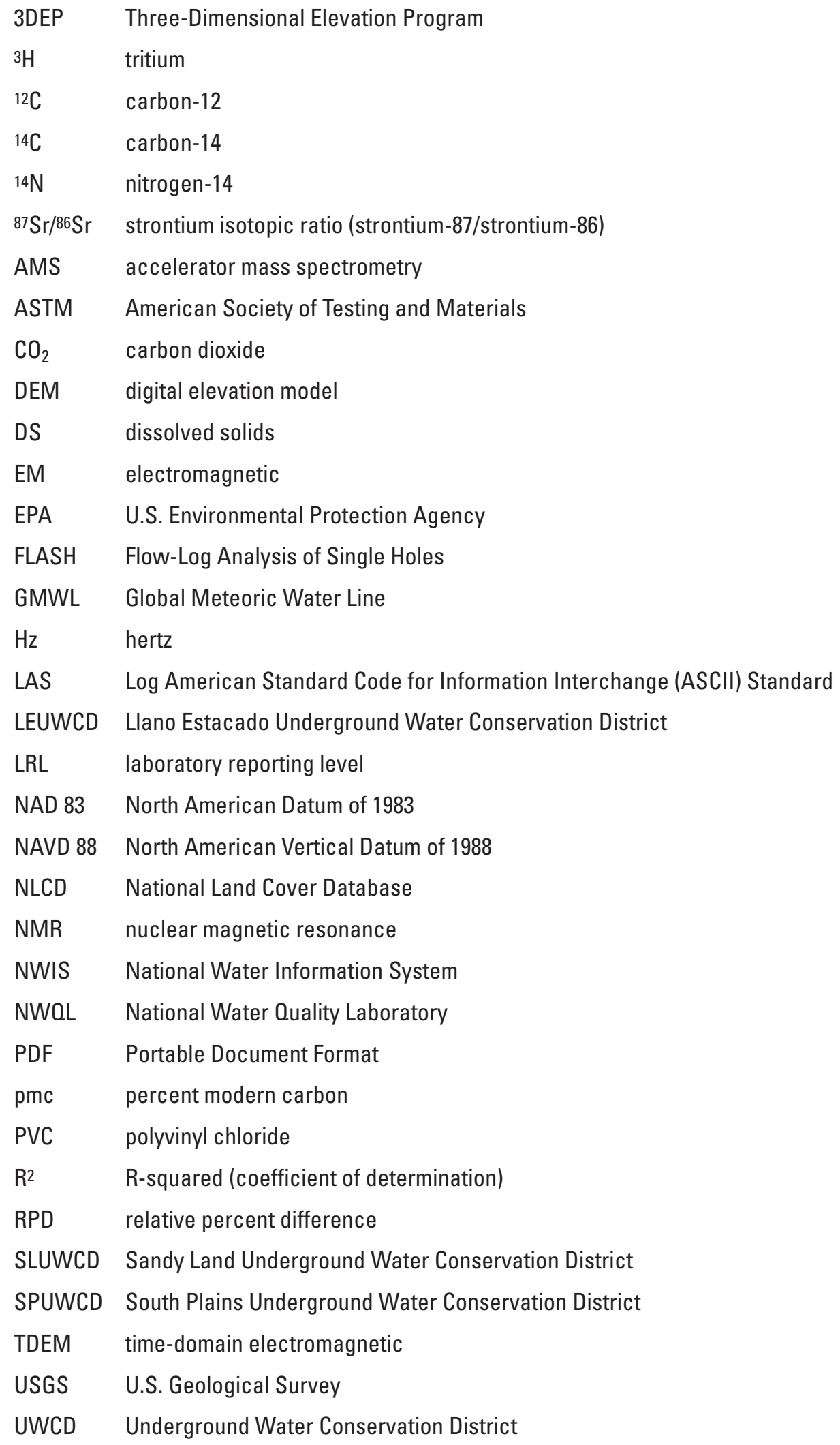





\title{
Hydrogeologic Framework, Geochemistry, Groundwater-Flow System, and Aquifer Hydraulic Properties Used in the Development of a Conceptual Model of the Ogallala, Edwards-Trinity (High Plains), and Dockum Aquifers In and Near Gaines, Terry, and Yoakum Counties, Texas
}

\author{
By Andrew P. Teeple, Patricia B. Ging, Jonathan V. Thomas, David S. Wallace, and Jason D. Payne
}

\section{Abstract}

In 2014, the U.S. Geological Survey, in cooperation with Llano Estacado Underground Water Conservation District, Sandy Land Underground Water Conservation District, and South Plains Underground Water Conservation District (hereinafter referred to collectively as the "UWCDs"), began a multiphase study in and near Gaines, Terry, and Yoakum Counties, Texas, to develop a regional conceptual model of the hydrogeologic framework, geochemistry, groundwater-flow system, and hydraulic properties, primarily for the High Plains and Edwards-Trinity aquifer system and to a lesser degree for the Dockum aquifer. The High Plains aquifer system (hereinafter referred to as the "Ogallala aquifer"), contained within the Ogallala Formation in Texas, is the shallowest aquifer in the study area and is the primary source of water for agriculture and municipal supply in the areas managed by the UWCDs. Groundwater withdrawals from deeper aquifers (primarily the Edwards-Trinity [High Plains] aquifer system that is hereinafter referred to as the "Edwards-Trinity [High Plains] aquifer") augmented by lesser amounts from the Dockum aquifer provide additional water sources in the study area. The EdwardsTrinity (High Plains) aquifer is contained within the Trinity and Fredericksburg Groups. The Dockum aquifer, a relatively minor source of water in the study area, is contained in the Dockum Group, which was evaluated as a single unit. The potential for continual declines of the groundwater in the Ogallala aquifer in the study area and the potential changes in water quality resulting from dewatering and increased vertical groundwater movement between adjacent water-bearing units have raised concerns about the amount and quality of available groundwater.

The developed conceptual model helped in the understanding of the quantity and quality of the groundwater within the Ogallala, the Edwards-Trinity (High Plains), and to a lesser extent, the Dockum aquifers within the study area. The hydrogeologic framework was used to assess the vertical and lateral extents of hydrogeologic units, bed orientations, unit thicknesses, and location and orientation of paleochannels. In general, the Trinity and Fredericksburg Groups and Ogallala Formation exhibit a slight regional dip (dip angle of about 0.14 degrees) to the southeast with dip directions becoming more to the south with each successively overlying unit $(105,110$, and 125 degrees for the bases of the Trinity and Fredericksburg Groups and Ogallala Formation, respectively). In general, the Trinity and Fredericksburg Groups thin to the south and are not present in the southern part of Gaines County, whereas the Ogallala Formation becomes thinner from west to east. The combined thickness of the Trinity and Fredericksburg Groups and Ogallala Formation is generally greatest in the north-central part of the study area and thinnest in the southeastern part of the study area. Paleochannel orientation varied over geologic time as formations were deposited and eroded.

Water-quality samples were collected from 51 wells throughout the study area to better understand general water quality and to provide insight into groundwater-flow paths and recharge areas. Groundwater samples were spatially grouped on the basis of similarities found in the physicochemical properties, major ions, trace elements, nutrients, organic compounds, and selected stable isotopes and age tracers. Three groundwater groups were identified in the study area. The first groundwater group (Group 1), represented mostly by groundwater from the Ogallala and Edwards-Trinity (High Plains) aquifers in the northern half of the study area, is considered to be recent recharge, affected by land-use activities, as explained by the younger age, higher concentrations of nitrate plus nitrite, and more frequent detections of organic compounds. Groundwater wells in the second groundwater group (Group 2) are typically in the southwestern and northwestern parts of the study area, and the groundwater in this group is considered to be groundwater recharged during the Pleistocene period, as explained by the relatively old age of the groundwater, high strontium stable 
isotope ratios, and hydrogen and oxygen stable isotope ratios. The last groundwater group (Group 3) is likely a mixture of groundwater from the first or second groups (or both) with a third, highly mineralized groundwater as explained by having the highest dissolved-solids concentrations in the study area and having some similarities to geochemical characteristics of samples from the first and second groups.

A groundwater-flow system analysis was done to understand the flow of groundwater throughout the aquifer system. Groundwater-level altitudes for the Ogallala, Edwards-Trinity (High Plains), and Dockum aquifers are generally higher in the northwestern part of the study area and lower in the southeastern part of the study area. Groundwater generally flows in a northwest to southeast direction across the study area in each of the aquifers. The groundwater-flow paths closely resemble the mapped paleochannels, indicating that within the study area, the groundwater flows preferentially along the paleochannels, especially within the Ogallala aquifer where dewatering of the aquifer results in a greater effect of the base structure on the flow of groundwater.

The Ogallala aquifer is unsaturated in localized areas in the study area; unsaturated areas are generally near the southern extent of the Edwards-Trinity (High Plains) aquifer, with the largest unsaturated area west of Seminole, Tex. The saturated thickness of the Ogallala aquifer is thickest (more than 125 feet) southeast of Seminole and west of Brownfield, Tex., near the border between Terry and Yoakum Counties. The saturated thickness of the combined Ogallala and EdwardsTrinity (High Plains) aquifers ranges from less than 10 feet along the far southern edge of the study area to more than 350 feet north and east of Brownfield, Tex., and along the border between Terry and Yoakum Counties.

The aquifer hydraulic properties, including hydraulic conductivity and specific yield, were estimated to better understand the ability of groundwater to move through the aquifer system and quantify the volume of available water in storage. The hydraulic-conductivity values varied greatly within the study area (ranging from about 0.03 to about 350 feet per day), and often large variations were found in the same area. Terry County contained the highest and lowest hydraulic conductivity values for the Ogallala aquifer, whereas Yoakum County contained the highest and lowest hydraulic conductivity values for the Edwards-Trinity (High Plains) aquifer. The highest hydraulic-conductivity values for the Dockum aquifer were in Gaines County, whereas the lowest hydraulic-conductivity values were in Terry County. The estimated specific yield values within the study area range from 0.01 to 0.36 . Higher specific yield values generally occurred in the western part of the study area except in the Ogallala aquifer where higher specific yield values were in the east. The Ogallala aquifer had the lowest specific yield range and the least specific yield variability among the three aquifers, whereas the Dockum aquifer had the highest specific yield range and the greatest specific yield variability.
Using the estimated saturated thickness and estimated specific yield grids, the water volumes of the Ogallala and Edwards-Trinity (High Plains) aquifers and the combined Ogallala and Edwards-Trinity (High Plains) aquifers were estimated. The available water in the Edwards-Trinity (High Plains) aquifer (16.6 million acre-feet) is almost double the available water in the Ogallala aquifer (8.8 million acrefeet). Although the Edwards-Trinity (High Plains) aquifer contains more available groundwater, pumping is more difficult because of the relatively low hydraulic conductivity and specific yield values compared to the Ogallala aquifer. Overall, the available water within the combined Ogallala and Edwards-Trinity (High Plains) aquifers is about 6.6, 10.2, and 8.6 million acre-feet for Gaines, Terry, and Yoakum Counties, respectively.

\section{Introduction}

Llano Estacado Underground Water Conservation District (LEUWCD), Sandy Land Underground Water Conservation District (SLUWCD), and South Plains Underground Water Conservation District (SPUWCD) (hereinafter referred to collectively as the "UWCDs") manage groundwater resources in a part of west Texas near the Texas-New Mexico State line (figs. 1 and 2). As described in Thomas and others (2016) and Thomas and others (2019), the UWCDs are responsible for managing the groundwater resources in their respective jurisdictions, which are Gaines County for the LEUWCD, Terry County and a small part of Hockley County for the SPUWCD, and Yoakum County for the SLUWCD; the study area for this report consists of the areas managed by the three UWCDs (fig. 2). Hockley County is a small part of the overall study area and will not be explicitly mentioned within the report. If data pertain to Hockley County, they will be referred to as "in and near Gaines, Terry, and Yoakum Counties" as opposed to "in Gaines, Terry, and Yoakum Counties."

An important source of water in the study area is the High Plains aquifer system, a vast regional aquifer system that underlies about 174,000 square miles $\left(\mathrm{mi}^{2}\right)$ from South Dakota to Texas (fig. 1) (Gutentag and others, 1984). Historically, the High Plains aquifer system was often referred to as the "Ogallala aquifer" throughout its extent in reference to the predominant water-bearing unit of the aquifer system, the Ogallala Formation (Dugan and others, 1994). The High Plains aquifer system is hereinafter referred to as "Ogallala aquifer" in this report because the Ogallala Formation is the only geologic unit of the High Plains aquifer system in Texas and because of the historical use of the term in the region. The Ogallala aquifer is the shallowest aquifer in the study area and is the primary source of water for agriculture and municipal supply in the areas managed by the UWCDs (Rettman and Leggat, 1966). Groundwater withdrawals from deeper aquifers (primarily from the Edwards-Trinity [High Plains] aquifer system, hereinafter referred to as the "Edwards-Trinity [High Plains] aquifer," as identified by the Texas Water Development 


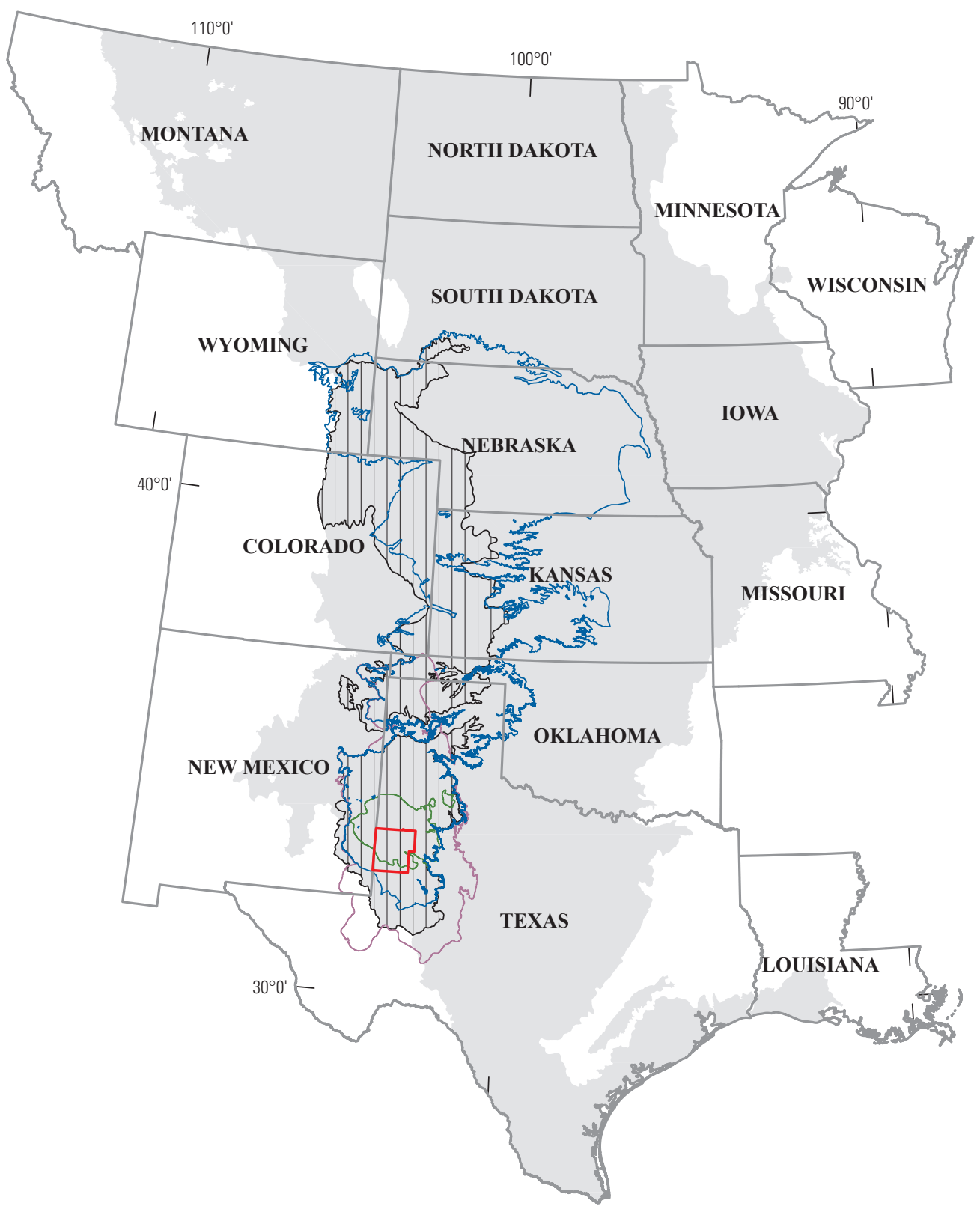

Base modified from U.S. Geological Survey 1:250,000-scale to 1:2,000,000-scale digital data, Texas Water Development Board digital data, Commission for Environmental Cooperation 1:10,000,000-scale digital data.

Albers Equal-Area Conic Projection, Texas State Mapping System North American Datum of 1983

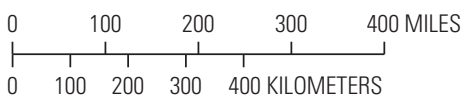

\section{EXPLANATION}
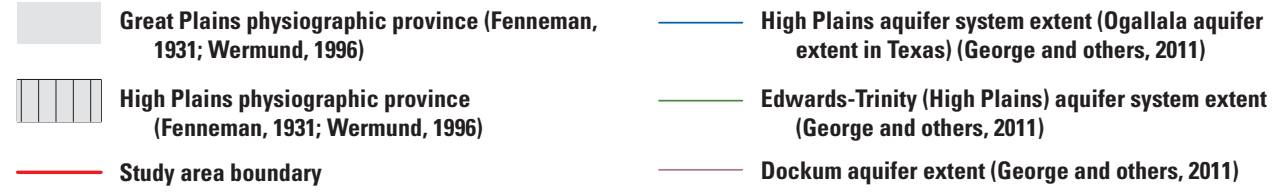

Figure 1. Location of the study area in Gaines, Terry, and Yoakum Counties, Texas, within the regional extent of the major aquifers and physiographic provinces pertaining to this assessment. Reprinted from Thomas and others (2016, fig. 2). 


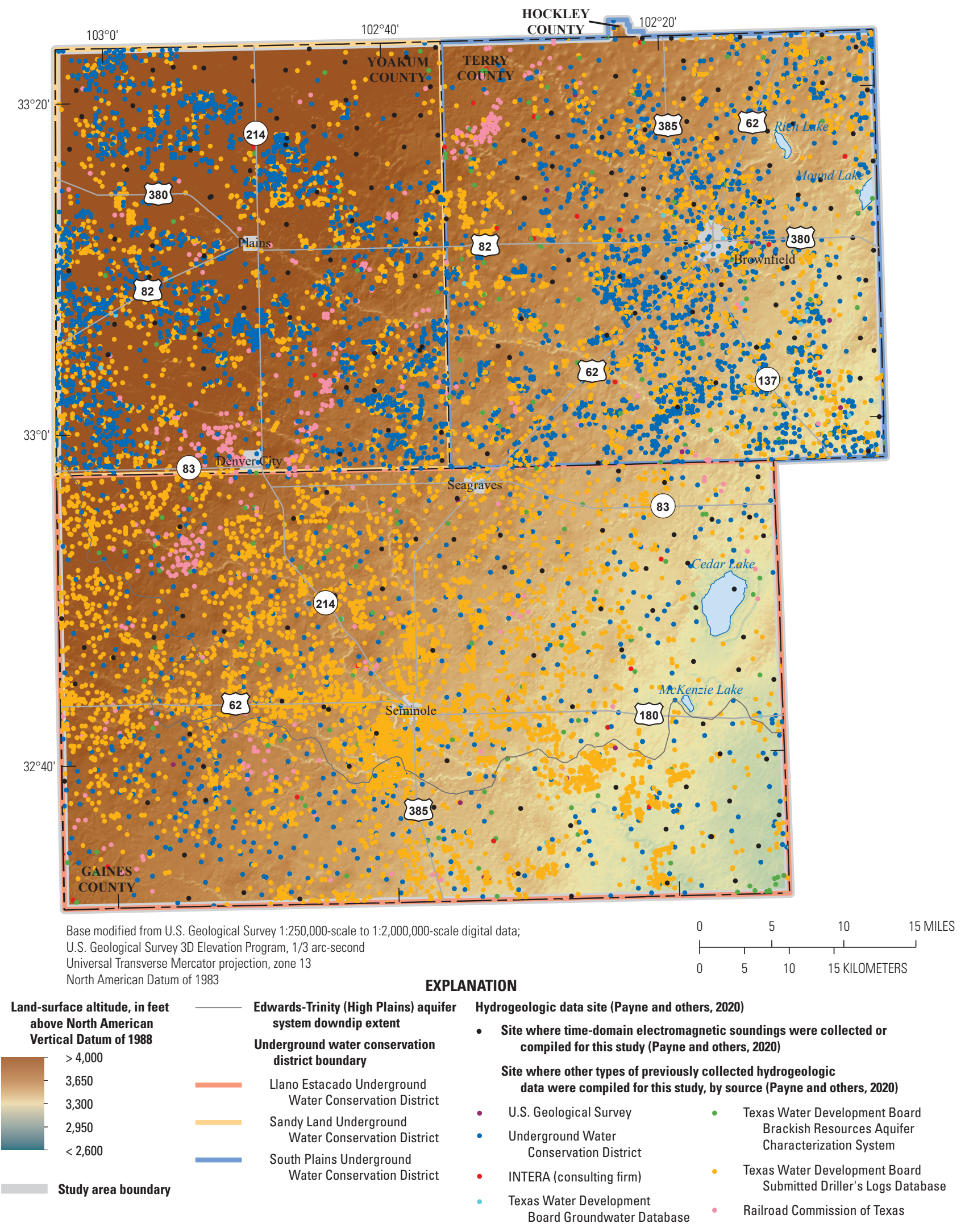

Figure 2. Hydrogeologic data sites, land-surface altitude, downdip extent of the Edwards-Trinity (High Plains) aquifer system, and study area extent, composed of the areas of jurisdiction of the Llano Estacado Underground Water Conservation District, Sandy Land Underground Water Conservation District, and South Plains Underground Water Conservation District, in and near Gaines, Terry, and Yoakum Counties, Texas. 
Board ${ }^{1}$ [Texas Water Development Board, 2020a], augmented by lesser amounts from the Dockum aquifer) provide additional water sources in the study area (fig. 1). The EdwardsTrinity (High Plains) aquifer is contained within the Trinity and Fredericksburg Groups, whereas the Dockum aquifer, a relatively minor source of water in the study area, is contained in the Dockum Group.

Groundwater levels have declined (decreased more than 50 feet [ft] compared to historical groundwater levels) in parts of west Texas including Gaines, Terry, and Yoakum Counties since 1938 with overall patterns of declines in the Ogallala aquifer beginning soon after the start of widespread irrigation practices relying on groundwater withdrawals from the aquifer (about 1950) (Gaum, 1953; Gutentag and others, 1984). In their report on the history of groundwater-level changes in the Ogallala aquifer from predevelopment to 1980 , Dugan and others (1994) report groundwater-level declines in the Ogallala aquifer of as much as $150 \mathrm{ft}$. During the past 50-60 years (1960-70), the rate of decline has slowed, and groundwater levels in the Ogallala aquifer have risen in a few areas (McGuire, 2017). The potential for continual declines of the groundwater in the Ogallala aquifer in the study area has raised concerns about the amount of available groundwater and long-term aquifer sustainability (Knowles and others, 1984; Peckham and Ashworth, 1993; Stovall, 2001; Blandford and others, 2003).

Also of concern are the potential changes in water-quality resulting from dewatering and increased vertical groundwater movement between adjacent water-bearing units (Weeks and others, 1988; Deeds and others, 2015). Large groundwater withdrawals in localized areas can lower hydraulic heads and cause vertical flow in hydraulically connected aquifer units because groundwater moves from areas of high hydraulic head to areas of low hydraulic head (Pischel and Gannett, 2015). Because the Ogallala aquifer and underlying aquifers are hydraulically connected in some locations, groundwaterlevel declines in the Ogallala aquifer and in the underlying Edwards-Trinity (High Plains) aquifer can result in changes in water quality when the waters are mixed by the upward movement of deeper, relatively more saline groundwater (Bradley and Kalaswad, 2003).

In 2014, the U.S. Geological Survey (USGS), in cooperation with the UWCDs, began a multiphase study to refine the understanding of the hydrogeologic framework, geochemistry, groundwater-flow system, and hydraulic properties to be included in the development of a regional conceptual model for the Ogallala, Edwards-Trinity (High Plains), and the Dockum aquifers (fig. 1). Available data were supplemented with additional geophysical data collected in selected areas to improve the spatial coverage and to reduce uncertainty

\footnotetext{
1The Edwards-Trinity aquifer is divided into two parts by the Texas Water Development Board-a "High Plains" part in west Texas referred to as the "Edwards-Trinity (High Plains) aquifer" that coincides with the study area of this report, and a "Plateau" part extending across much of the southwestern part of the State referred to as the "Edwards-Trinity (Plateau) aquifer" (George and others, 2011).
}

regarding hydrogeologic unit extents. Water-quality samples were collected to characterize water quality and to provide insights into groundwater-flow paths and recharge areas. The results of the first phase of the study are documented in Thomas and others (2016) and included an assessment of the differences between early development (1930-60) and recent (2005-15) groundwater-level altitudes and selected waterquality constituents (dissolved-solids [DS] and nitrate concentrations) for the Ogallala, Edwards-Trinity (High Plains), and Dockum aquifers. The results of the second phase of the study are documented in Thomas and others (2019) and include a refined understanding of the hydrogeologic framework in the study area.

\section{Purpose and Scope}

This report synthesizes previously collected data from Thomas and others (2016) and Thomas and others (2019) concerning the hydrogeologic framework, geochemistry, groundwater-flow system, and hydraulic properties of the groundwater system from the Ogallala, Edwards-Trinity (High Plains), and Dockum aquifers in west Texas with newly collected data in a regional conceptual model of the aquifers. A regional conceptual model was developed in order to better understand the amount and quality of available groundwater by combining information from a refined understanding of the hydrogeologic framework, geochemistry data, and information pertaining to the groundwater-flow system and aquifer hydraulic properties.

A groundwater-flow system analysis was done to gain a better understanding of the flow of groundwater throughout the aquifer system by incorporating information identified from the hydrogeologic framework and the geochemical analysis. Synoptic groundwater-level measurements were made within each of the aquifers to aid in the understanding of the groundwater-flow system. To estimate the hydraulic properties for the aquifer system, historical data were compiled and supplemented by collecting additional borehole and surface geophysical data. The Dockum Group, a relatively minor source of water in the study area, was evaluated as a single unit. The water-bearing units of the Dockum Group were not evaluated for this study; only ancillary data from the Dockum aquifer were used to aid in the interpretation of the overlying units. Neither the unit thickness nor storage properties of the Dockum aquifer were determined.

\section{Description of Study Area}

The study area is in the Great Plains physiographic province (fig. 1) and consists of an elevated and relatively undissected plain (Ryder, 1996). The study area covers about $3,225 \mathrm{mi}^{2}$, including $1,525 \mathrm{mi}^{2}$ in LEUWCD, $798 \mathrm{mi}^{2}$ in SLUWCD, and $902 \mathrm{mi}^{2}$ in SPUWCD (fig. 2) (Llano Estacado Underground Water Conservation District, 2020a; Sandy Land Underground Water Conservation District, 2020; South 
Plains Underground Water Conservation District, 2020a). As of July 1,2018, the population of the study area was about 42,000 (U.S. Census Bureau, 2020).

The climate of the study area is semiarid (Larkin and Bomar, 1983). Precipitation averages 18.8 inches per year, mostly in the form of rain (National Oceanic and Atmospheric Administration, 2010). The potential evapotranspiration is more than three times the annual precipitation (Larkin and Bomar, 1983). The average annual temperature during 1981-2010 for the study area was about 60.5 degrees Fahrenheit $\left({ }^{\circ} \mathrm{F}\right)$, with the warmest average monthly temperature in July $\left(79.1^{\circ} \mathrm{F}\right)$ and the coolest average monthly temperature in January $\left(40.0^{\circ} \mathrm{F}\right.$ ) (National Oceanic and Atmospheric Administration, 2010).

The combination of minimal topographic relief, availability of groundwater for irrigation, and excellent soils makes this an important agricultural region in Texas (Ryder, 1996). From the USGS National Land Cover Database (NLCD) 2011, the land-cover categories for rangeland (shrubs/scrubs [31 percent] and grassland/herbaceous [19 percent]) and for cultivated crops (42 percent) dominate in the study area (fig. 3) (Homer and others, 2015). The top crop in the study area is cotton with about $858 \mathrm{mi}^{2}$ planted in 2017 (U.S. Department of Agriculture, 2019). Other important crops in the study area are peanuts (184 $\mathrm{mi}^{2}$ planted), sorghum $\left(65 \mathrm{mi}^{2}\right.$ planted), forage (37 $\mathrm{mi}^{2}$ planted), wheat (33 $\mathrm{mi}^{2}$ planted), corn (12 $\mathrm{mi}^{2}$ planted), vegetables ( $7 \mathrm{mi}^{2}$ planted), and sunflower seeds ( $7 \mathrm{mi}^{2}$ planted). Water use in the study area is almost all from groundwater sources ( 99 percent) with 97 percent of the groundwater used for irrigation (Texas Water Development Board, 2017).

\section{Geologic Setting}

The Triassic-age Dockum Group underlies the Cretaceous-age Trinity and Fredericksburg Groups and the Ogallala Formation (fig. 4) throughout much of the southern part of the High Plains physiographic province (fig. 1). The Dockum Group consists of siltstone, mudstone, and shale with a small amount of sandstone originally deposited in fluvial and lacustrine environments (McGowen and others, 1979; Bradley and Kalaswad, 2003). The overlying Trinity Group consists of sand and gravel layers (fig. 4). The Trinity Group is overlain by the Fredericksburg Group, which is composed of clay, shale, and limestone (Bell and Morrison, 1979). A thin layer of the Cretaceous-age Washita Group is present in the northern and northeastern parts of the study area. The Washita Group, which overlies the Fredericksburg Group, consists of shale and limestone. For this study, the Washita Group is interpreted to be part of the Fredericksburg Group because it is difficult to distinguish the contact between the Fredericksburg and Washita Groups and because the Washita Group has been thinned or completely removed at many locations in the study area (Brand, 1953; Fallin, 1989). Prior to the deposition of the
Ogallala Formation, erosional processes formed a complex, irregular surface in the underlying sediments of the Trinity and Fredericksburg Groups and thinned the geologic units in many places. The late Miocene- to early Pliocene-age Ogallala Formation is composed primarily of poorly sorted gravel, sand, silt, and clay, which in many places were deposited in paleochannels and alluvial deposits. Thicker alluvial deposits of Ogallala Formation rocks occur in areas where erosion of the underlying Cretaceous-age rocks was most extensive (Bradley and Kalaswad, 2003). The Ogallala Formation directly overlies the Dockum Group where the Trinity and Fredericksburg Groups are absent (Ashworth and Hopkins, 1995) (fig. 4).

\section{Hydrogeologic Setting}

The Ogallala aquifer is a major aquifer in the study area; it is unconfined and is contained within the Ogallala Formation (fig. 4). Multiple studies describe the general structure of the Ogallala aquifer as featuring paleochannels eroded into the underlying hydrogeologic units; paleochannels are important conduits for groundwater flow and are filled with coarse gravel in the channel and often filled with sand and finer sediments in the interchannel areas (for example, Cronin, 1969; Seni, 1980; Gustavson, 1996). The variable distribution of coarse, permeable sediments affects the spatial differences in the water-storage capacity and water-availability characteristics (Seni, 1980; Texas Water Development Board, 2020b). DS concentrations in the Ogallala aquifer typically are less than 1,000 milligrams per liter $(\mathrm{mg} / \mathrm{L}$ ) (the upper limit for what is generally considered freshwater [Winslow and Kister, 1956]) but can range from less than 600 to more than $6,000 \mathrm{mg} / \mathrm{L}$ within localized parts of the study area (Llano Estacado Underground Water Conservation District, 2020a; Llano Estacado Underground Water Conservation District, 2020b; South Plains Underground Water Conservation District, 2020b). In many areas, groundwater moves vertically between the Ogallala aquifer and the underlying EdwardsTrinity (High Plains) and Dockum aquifers (fig. 1; fig. 4).

The Edwards-Trinity (High Plains) aquifer is a minor, semiconfined aquifer underlying the Ogallala aquifer, except in the southern part of the study area where the EdwardsTrinity (High Plains) aquifer is absent (George and others, 2011) (fig. 1; fig. 4). The Edwards-Trinity (High Plains) aquifer is contained within the Trinity and Fredericksburg Groups where the Fredericksburg Group acts as a semiconfining unit to the more permeable Trinity Group. Groundwater flow in the Edwards-Trinity (High Plains) aquifer is controlled by facies changes, structure orientation, local cementation, and paleochannels that can produce local deviations in flow patterns (Fallin, 1989). Groundwater from the Edwards-Trinity (High Plains) aquifer is typically slightly saline (DS concentrations range from 1,000 to 3,000 $\mathrm{mg} / \mathrm{L}$ ) (Winslow and Kister, 


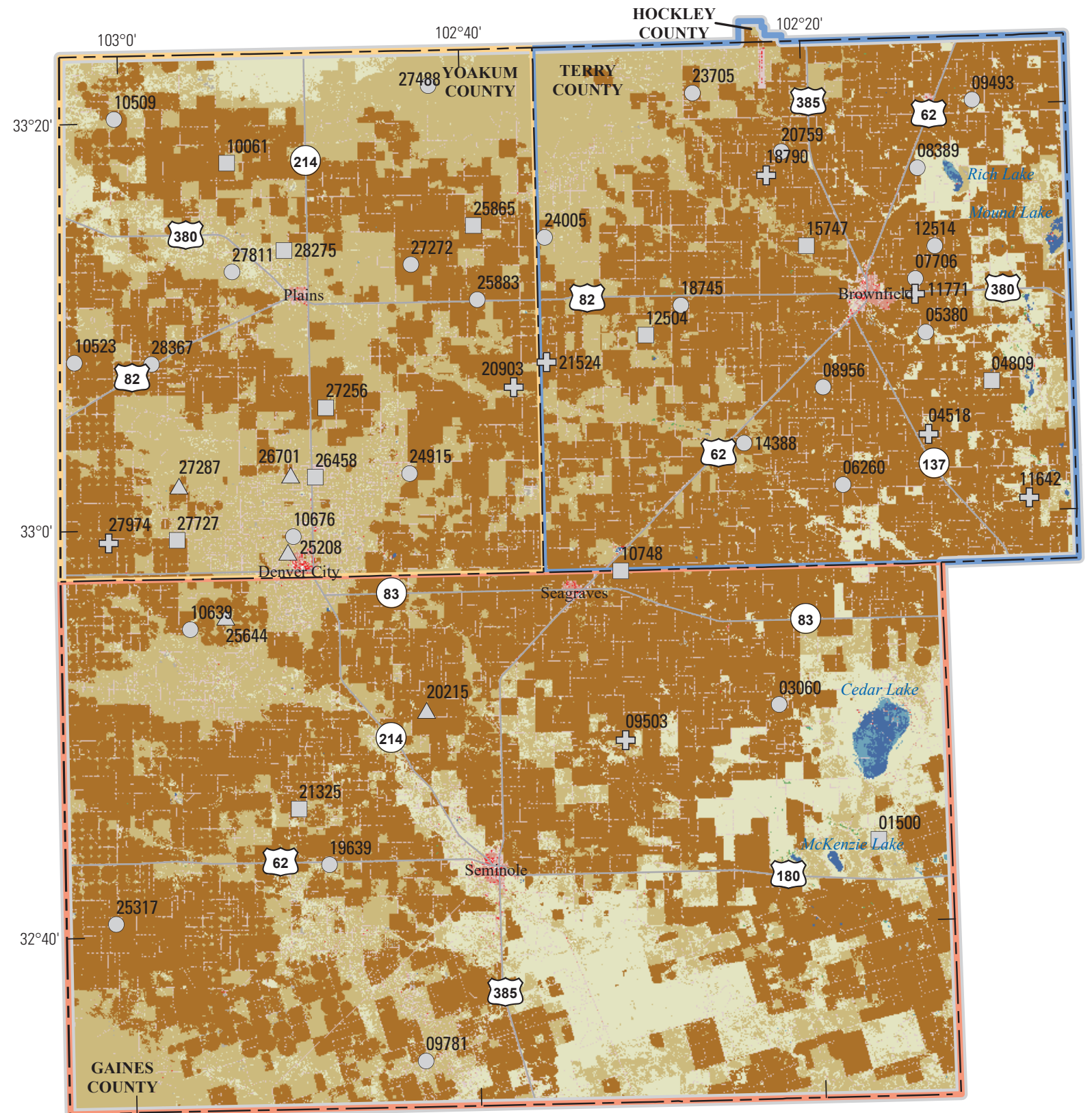

Base from U.S. Geological Survey National Land Cover Database Universal Transverse Mercator projection, zone 13

North American Datum of 1983

EXPLANATION

Land-cover category (Homer and others, 2015)

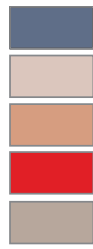

Open water

Developed, open space

Developed, low intensity

Developed, medium intensity

Barren land (rock/sand/clay)

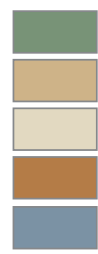

Study area boundary

Deciduous forest

Shrub/scrub

Grassland/herbaceous

Cultivated crops

Emergent herbaceous wetland

\begin{tabular}{|c|c|c|}
\hline$T$ & $T$ & 1 \\
\hline 5 & 10 & 15 KILOMETERS \\
\hline
\end{tabular}

15 MILES

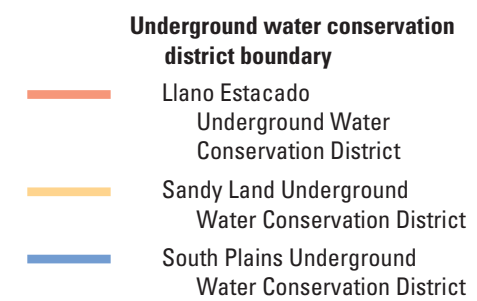

Well and identifier, by aquifer (table 2)

\section{(Payne and others, 2020)}

Completed in the High Plains aquifer system (Ogallala aquifer)

Completed in the Edwards-Trinity (High Plains) aquifer system

$\triangle$ Completed in the Dockum aquifer

گ Completed in a combination of aquifers

Figure 3. National Land Cover Database 2011 land-cover categories and locations of wells from which samples for water-quality data were collected in Gaines, Terry, and Yoakum Counties, Texas, 2014 and 2016. 


\begin{tabular}{|c|c|c|c|c|c|}
\hline Era & Period & Epoch or series & $\begin{array}{c}\text { Geologic unit group } \\
\text { or formation }\end{array}$ & Lithologic descriptions & Hydrogeologic unit \\
\hline \multirow{2}{*}{ Cenozoic } & \multirow{2}{*}{ Tertiary } & Pliocene & \multirow{2}{*}{ Ogallala Formation } & \multirow{2}{*}{$\begin{array}{l}\text { Gravel, sand, silt, } \\
\text { and clay }\end{array}$} & \multirow{2}{*}{$\begin{array}{l}\text { High Plains } \\
\text { aquifer system } \\
\text { (Ogallala aquifer) }\end{array}$} \\
\hline & & Miocene & & & \\
\hline \multirow{4}{*}{ Mesozoic } & \multirow{3}{*}{ Cretaceous $^{1}$} & \multirow{3}{*}{$\begin{array}{l}\text { Comanchean } \\
\text { Series }\end{array}$} & Washita Group $^{2}$ & Shale and limestone & \multirow{3}{*}{$\begin{array}{l}\text { Edwards-Trinity } \\
\text { (High Plains) } \\
\text { aquifer system }\end{array}$} \\
\hline & & & Fredericksburg Group & $\begin{array}{l}\text { Clay, shale, and } \\
\text { limestone }\end{array}$ & \\
\hline & & & Trinity Group & Sand and gravel & \\
\hline & Triassic & Upper & Dockum Group & $\begin{array}{l}\text { Siltstone, mudstone, } \\
\text { shale, and sandstone }\end{array}$ & Dockum aquifer \\
\hline
\end{tabular}

${ }^{1}$ Geologic and hydrogeologic units and lithologic descriptions are absent outside the spatial extents of the Edwards-Trinity (High Plains) aquifer system.

${ }^{2}$ For this study, the Washita Group has been interpreted to be part of the Fredericksburg Group because it is difficult to distinguish from the top of the Fredericksburg Group and has been thinned or completely removed at many locations (Brand, 1953; Fallin, 1989).

Figure 4. Geologic and hydrogeologic units and lithologic descriptions in and near Gaines, Terry, and Yoakum Counties, Texas. Modified from Knowles and others (1984); Clark and others (2014); Thomas and others (2016); Thomas and others (2019).

1956; Fallin, 1989) and contains more DS than groundwater from the overlying Ogallala aquifer (George and others, 2011) (fig. 1; fig. 4).

The Dockum aquifer is a minor confined aquifer in the study area (George and others, 2011) and underlies the Ogallala and Edwards-Trinity (High Plains) aquifers (fig. 4) throughout much of the southern part of the High Plains physiographic province (fig. 1). Groundwater in the Dockum aquifer is characterized by high concentrations of DS and other constituents that exceed secondary drinking water standards (U.S. Environmental Protection Agency, 2020) as well as high concentrations of sodium that may negatively affect irrigated crops (Bradley and Kalaswad, 2003).

\section{Synopsis of Previous Studies for This Multiphase Project}

Thomas and others (2016) described the results of the first phase of the study, during which groundwater-levelaltitude and selected water-quality data from wells in and near Gaines, Terry, and Yoakum Counties, Texas, were compiled and evaluated for the Ogallala, Edwards-Trinity (High Plains), and Dockum aquifers. Readily available digital groundwater data for the study area (geologic, well-construction, groundwater-level-altitude, and selected water-quality data) were compiled to assess temporal and spatial changes in groundwater resources from early development (1930-60) to recent (2005-15) periods. Potentiometric-surface maps were created to depict changes in groundwater-level altitudes for the Ogallala and Edwards-Trinity (High Plains) aquifers.
Existing DS and nitrate concentration data were compiled and assessed for spatial patterns and changes over time. It was determined that groundwater-level altitudes of the Ogallala aquifer were generally higher in the northwestern part of the study area and lower in the southeastern part of the study area with groundwater-flow paths generally adhering to a northwest to southeast direction across the study area. For the EdwardsTrinity (High Plains) aquifer potentiometric-surface map, a general northwest to southeast flow gradient was evident. Maps of groundwater-level-altitude changes between the early development (1930-60) and recent periods (2005-15) for the Ogallala aquifer and the Edwards-Trinity (High Plains) aquifer were generally similar and indicate that groundwater-level altitudes have declined over a large part of the area. DS concentrations of less than $1,000 \mathrm{mg} / \mathrm{L}$ were predominantly measured in the western part of the study area. A general pattern of increasing nitrate concentrations from west to the northeast was evident in the study area.

Thomas and others (2019) refined the hydrogeologic framework of the study area by compiling available hydrogeologic data and information from interpretive studies with additional borehole and surface-geophysical data. The resulting dataset was analyzed to identify the extent and thickness of selected hydrogeologic units in the study area. Most of the locations where the altitude of the base (bottom) of the Ogallala aquifer was higher (shallower) than previously depicted are in the southern part of the study area. Thomas and others (2019) determined that the average altitude of the base of the Ogallala aquifer is approximately $1.7 \mathrm{ft}$ lower (deeper) compared to previously published information on the altitude of the base of the aquifer (Deeds and others, 2015), 
resulting in a subsequent increase in the saturated thickness by the same amount. The saturated thickness of the Ogallala aquifer ranges from less than $10 \mathrm{ft}$ in the far southern extent of the study area to more than $150 \mathrm{ft}$ southeast of Seminole, Tex., and northwest of Brownfield, Tex. (fig. 2). Although the Trinity and Fredericksburg Groups are present throughout most of the northern parts of the study area, there are localized areas where one or both groups are thin or absent. The average unit thicknesses of the Trinity and Fredericksburg Groups are $55 \mathrm{ft}$ and $86 \mathrm{ft}$, respectively. The Trinity Group is generally thicker in the eastern part of the study area with the thickest part in a localized area in northeastern Yoakum County (about $164 \mathrm{ft}$ thick). The Fredericksburg Group is generally thicker in the north-central part of the study area with the thickest part being about $237 \mathrm{ft}$ thick. Relative to the other geologic units assessed for the study, the Dockum Group has a much larger average unit thickness of approximately $1,795 \mathrm{ft}$. The top of the Dockum Group is deepest to the north where the Trinity and Fredericksburg Groups are present and shallowest to the south where it directly underlies the Ogallala Formation.

\section{Development of a Refined Hydrogeologic Framework}

The term "hydrogeologic framework" as used in this report refers to the geospatial extents of hydrogeologic units, bed orientation, unit thickness, and outcrop and subcrop locations in the study area. The hydrogeologic framework of Thomas and others (2019) was updated by using newly collected hydrogeologic data. The resulting dataset was analyzed to refine the extents and thicknesses of the Dockum, Trinity, and Fredericksburg Groups and the Ogallala Formation.

\section{Data Compilation and Collection}

For this study, the data in Teeple and others (2018), which were used to develop the hydrogeologic framework in Thomas and others (2019), were used as the base dataset in the refinement of the hydrogeologic framework. The data were modified to account for duplicate sites, redefined tops and bases of the hydrogeologic units, and updated site altitudes obtained from a digital elevation model (DEM). More than 12,000 additional digital data records consisting of hydrogeologic information were compiled and added to the existing 9,822 hydrogeologic records. Although the composite dataset contained more than 22,000 hydrogeologic records, spatial gaps existed within the dataset. Additional time-domain electromagnetic (TDEM) soundings were collected at 24 targeted locations, where spatial gaps were identified, to supplement the original 234 TDEM soundings to improve the spatial coverage across the study area and to further reduce uncertainty within the hydrogeologic framework.
Surface geophysical resistivity methods such as TDEM soundings, can be used to detect changes in the electrical properties of the subsurface (Zohdy and others, 1974). The electrical properties of soil and rock are determined by water content, porosity, clay content and mineralogy, and conductivity (or reciprocal of electrical resistivity) of the pore water (Lucius and others, 2007). TDEM instruments measure the bulk resistivity of the subsurface by producing an alternating electrical current in a transmitter loop deployed on the land surface (Vignesh and others, 2015). TDEM soundings were collected using the Geonics Protem 47 and 57 systems (Geonics Limited, 2006a; Geonics Limited, 2006b). The Geonics Protem 47 and 57 systems use a multiturn receiver coil to measure electromagnetic (EM) fields in the center of a transmitter loop. The TDEM soundings were collected at two frequencies using the Geonics Protem 47 (285 and 75 hertz [Hz]) and three frequencies using the Geonics Protem $57(30,7.5$, and $3.0 \mathrm{~Hz})$ for a total of five frequencies. The lower frequencies receive data from deeper in the subsurface. For each frequency, 10 stacks were collected by using an integration time of either 8 or 15 seconds. The longer integration time (15 seconds) was used for collecting 3.0-Hz data with the Geonics Protem 57; the longer integration time helped compensate (improve signal to noise ratio) for the dissipation of the transmitted signal at depth and for the greater potential for EM background noise with these soundings compared to soundings collected at higher frequencies (shallower depths). Additional information about the TDEM method and data collected in this study are available in Payne and others (2020). The TDEM data were collected in accordance with methods defined by the American Society of Testing and Materials (ASTM) (American Society of Testing and Materials, 1999).

For each TDEM sounding, the voltages measured from the eddy currents were averaged and evaluated statistically by using preprocessing scripts that use the raw field data (voltage data) and compute the uncertainty of each time gate (discrete voltages measured at increasingly later times after shutoff of the current) independently. Variability observed in a time gate could represent signal noise or a systematic change not representative of stable data. In this application, 10 percent of the data from each end of the distribution were removed, and an average of the central 80 percent of the data was computed. The resulting averages were then compared to a noise sample collected at the sounding location, and any values less than one-half the associated EM background noise value were removed from the final sounding. The final averaged values for each time gate were saved as processed data files and used for inverse modeling. Inverse modeling is the process of estimating the spatial distribution of subsurface resistivity from the measured voltage. The IX1D v3 program, developed by Interpex Limited (1996), was used for inverse modeling of the TDEM soundings. A smooth inverse model (a multilayered model that holds the depth values fixed and allows the resistivity values to vary during inversion) was fit to the data by using Occam's inversion principle, a preferred-homogeneity regularization condition (Constable and others, 1987). To better represent the electrical stratigraphy of each sounding, layered-earth models 
(simplified models used to represent hydrogeologic units) were then generated and fit to the data. The changes in resistivity from the inverse modeling results of the final processed TDEM data were used to determine changes of hydrogeologic contacts (the tops and bases of hydrogeologic units).

Land-surface altitudes were determined from a DEM for all well and TDEM locations using their horizontal coordinates to provide consistency and improve accuracy. DEM data were obtained from the Three-Dimensional Elevation Program (3DEP) (U.S. Geological Survey, 2017) to estimate land-surface altitudes across the study area. Depths to tops and bases of the hydrogeologic units were converted to altitudes by subtracting the depths from the 3DEP DEM. Then, depth data were referenced by altitude and spatial location for correlation among neighboring wells to create a regional network of data points.

\section{Methods of Interpretation}

The tops and bases of the hydrogeologic units from all the data released in Payne and others (2020) was used to create hydrogeologic unit surface grids. Hydrogeologic unit surface grids were created by using Oasis montaj (Seequent, 2020a) and kriging techniques as described in Thomas and others $(2019$, p. 8). Gridded hydrogeologic unit surface grids were iteratively compared to interpreted contact altitudes to evaluate outliers, grid accuracy, and clustered data. All outlier locations were evaluated through a correlation process to determine data-point uncertainty. The correlation process involved the comparison of hydrogeologic unit contacts between given sites to nearby sites and preliminary grids. After hydrogeologic unit data were processed, outlying data were reviewed by comparing them with the original source data. If the original source data were deemed questionable, then the outlying data were removed. Throughout the process, all hydrogeologic unit contacts were reviewed and revised as needed to provide the best possible final representation of each hydrogeologic unit (Payne and others, 2020).

Paleochannel location and orientation varied over geologic time as formations were deposited and eroded. Two methodologies were utilized to evaluate paleochannels in each formation across the study area: (1) trend-removal grid analysis and (2) hydrology toolset analysis. Trend-removal grids were developed by removing the third-order regional trend from all the point values within the hydrogeologic unit surface grids (Seequent, 2020b). The resulting trend-removal grid shows changes from the removed regional trend. Relatively low values represent low points in the hydrogeologic unit surface grid where continuous stretches of low points can be indicative of paleochannels. For the second method, the hydrogeologic unit surface grids were treated as if they were surface DEMs, and a topographic watershed delineation was simulated across the surface. Esri's ArcMAP Hydrology toolset was utilized to determine the flow direction, flow accumulation, stream links, and stream order (Esri, 2016). Ultimately, the hydrology toolset simulates the movement of water across a surface, which for this study would correspond to paleochannels in the hydrogeologic unit surface grids.

\section{Hydrogeologic Framework Refinements}

Hydrogeologic unit surface grids were used to assess the thickness and extent of the hydrogeologic units and to interpret paleochannel locations. The refined hydrogeologic unit surface grids revised during this assessment (fig. 5) were compared to previously mapped surfaces to evaluate recent hydrogeologic framework refinements (fig. 6; Thomas and others, 2019). Both trend-removal grid analysis and hydrology toolset analysis methods were used to locate the paleochannels eroded into the Dockum, Trinity, and Fredericksburg Groups (as observed in the base of the Trinity and Fredericksburg Groups and Ogallala Formation, respectively) (fig. 7). In this report, a deep paleochannel is defined as having a trend-removal value of less than $-25 \mathrm{ft}$, and a moderately deep paleochannel is defined as having a trend-removal value between -10 and $-25 \mathrm{ft}$. Thickness grids for each hydrogeologic unit were computed by subtracting the altitudes of the lower hydrogeologic unit surface grid from the altitudes of the overlying hydrogeologic unit surface grid (fig. 8). Descriptive statistics for the hydrogeologic framework results are summarized in table 1.

\section{Dockum Group}

The altitudes of the base of the Dockum Group range from about $350 \mathrm{ft}$ above North American Vertical Datum of 1988 (NAVD 88) north of Cedar Lake near the border between Gaines County and Terry County to about 2,120 ft above NAVD 88 at the southwest corner of the study area (fig. $5 A$ ). The revised base of the Dockum Group is deeper than previously reported in Thomas and others (2019) (table 1; fig. 6A). The base of the Dockum Group is less than -150 ft (shallower) than previously reported, mostly in the eastern Gaines County and southern Terry County. The western part of the study area is greater than $300 \mathrm{ft}$ (deeper) than previously reported in Thomas and others (2019). Large differences in the revised base of the Dockum Group from the previously reported base in Thomas and others (2019) are a result of the inclusion of an additional 29 values (an increase from 312 to 341 values) used to revise the hydrogeologic unit surface. Also, there were relatively few points to interpolate the base of the Dockum Group throughout the study area, which introduces large variations with the inclusion or redefinition of data values.

The altitudes of the top of the Dockum Group (bases of the Trinity Group and Ogallala Formation [where the Trinity Group is not present]) range from about 2,790 ft to about $3,610 \mathrm{ft}$ above NAVD 88 . The highest altitudes are in the 
Table 1. Descriptive statistics for the primary geologic units for each conservation district in the study area in and near Gaines, Terry, and Yoakum Counties, Texas.

[LEUWCD, Llano Estacado Underground Water Conservation District; SPUWCD, South Plains Underground Water Conservation District; SLUWCD, Sandy Land Underground Water Conservation District]

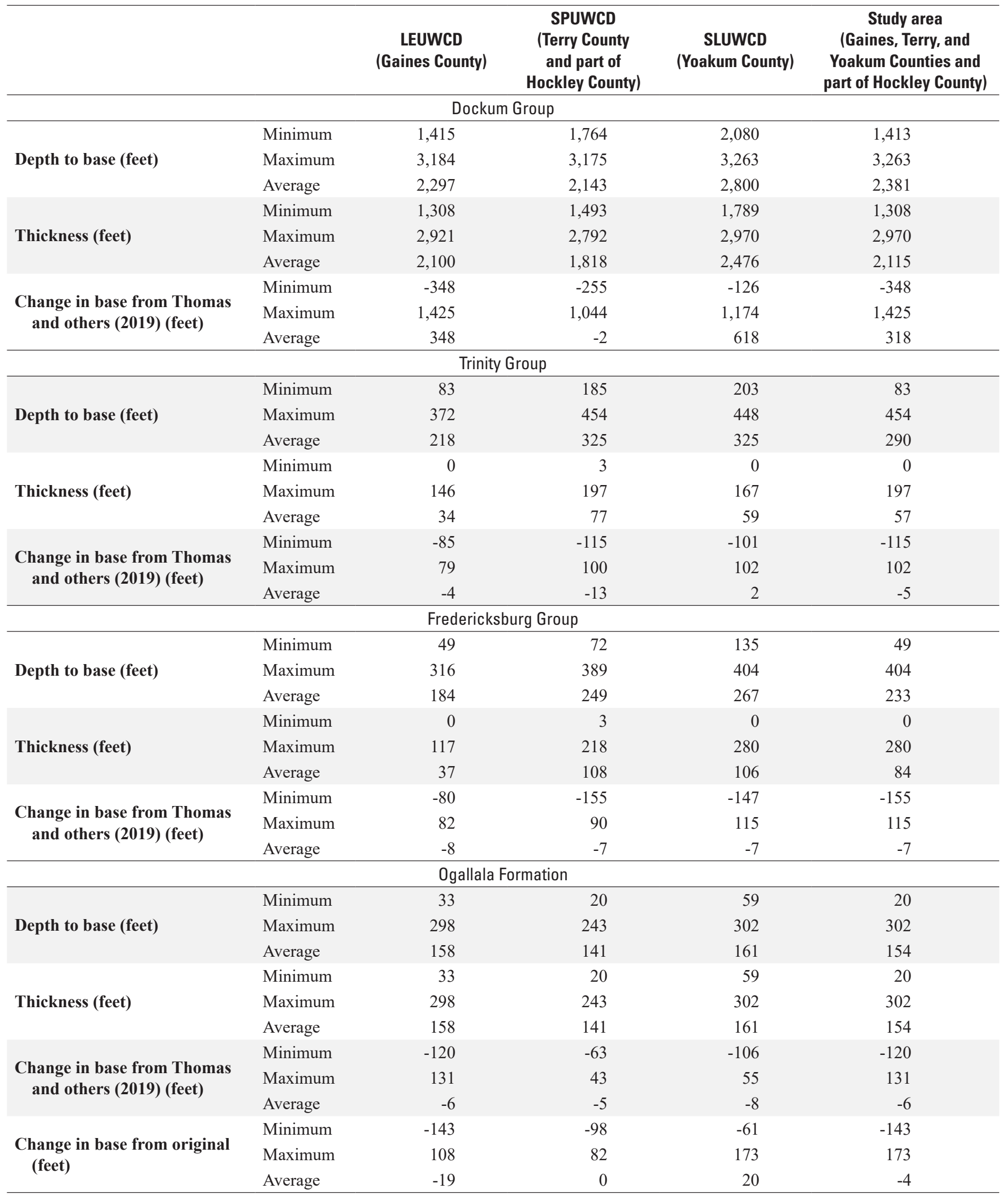




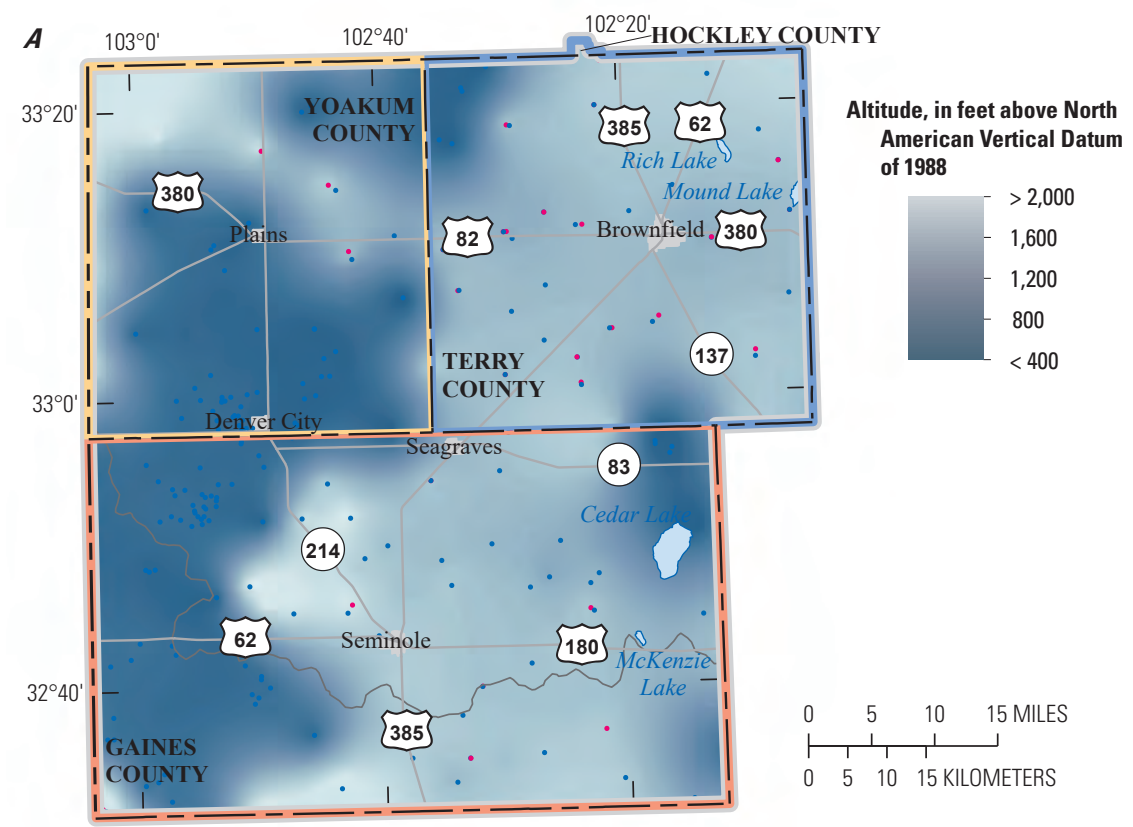

\section{EXPLANATION}

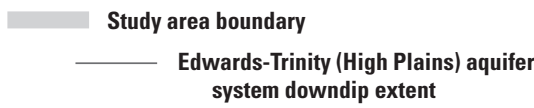

Underground water conservation district boundary

Llano Estacado Underground Water

Conservation District

Sandy Land Underground Water Conservation District

South Plains Underground Water Conservation District

Hydrogeologic data site, by method of interpretation (Payne and others, 2020)

Time-domain electromagnetic sounding

Geophysical log

Driller's description

Reported value (method of interpretation was unknown)

Base modified from U.S. Geological Survey 1:250,000-scale to 1:2,000,000-scale digital data,

Universal Transverse Mercator projection, zone 13

North American Datum of 1983

Figure 5. Revised (2020) hydrogeologic unit surfaces for $A$, the base (bottom) of the Dockum Group, $B$, the base of the Trinity Group, $C$, the base of the Fredericksburg Group, and $D$, the base of the Ogallala Formation in and near Gaines, Terry, and Yoakum Counties, Texas. 


\section{EXPLANATION}

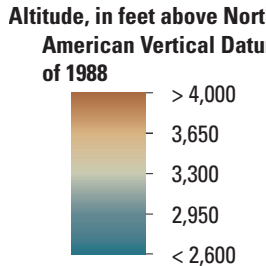

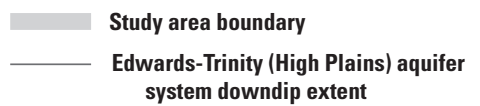
system downdip extent

Underground water conservation district boundary Llano Estacado Underground Water Conservation District

Sandy Land Underground Water Conservation District

South Plains Underground Water Conservation District

Hydrogeologic data site, by method of interpretation (Payne and others, 2020)

Time-domain electromagnetic sounding

Geophysical log

Driller's description

Reported value (method of interpretation was unknown)

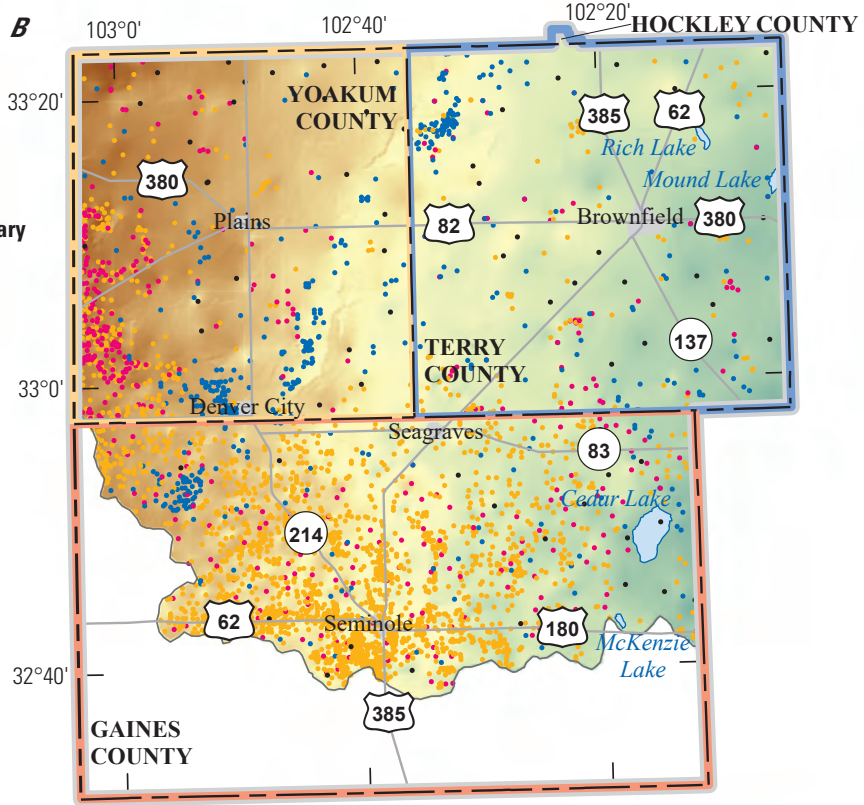

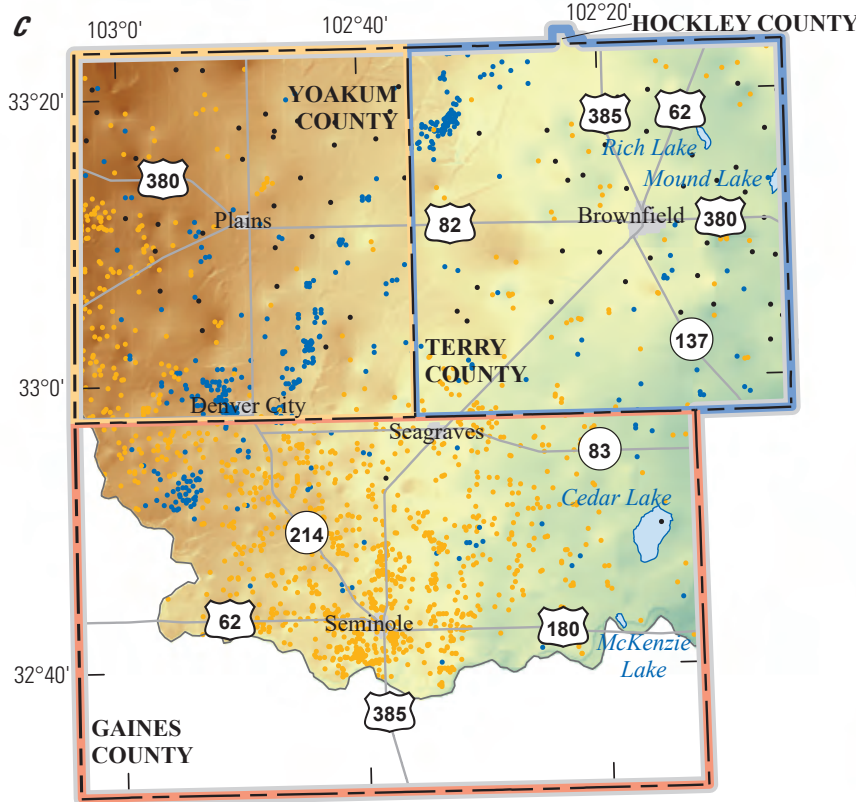

Base modified from U.S. Geological Survey 1:250,000-scale to 1:2,000,000-scale digital data Universal Transverse Mercator projection, zone 13

North American Datum of 1983

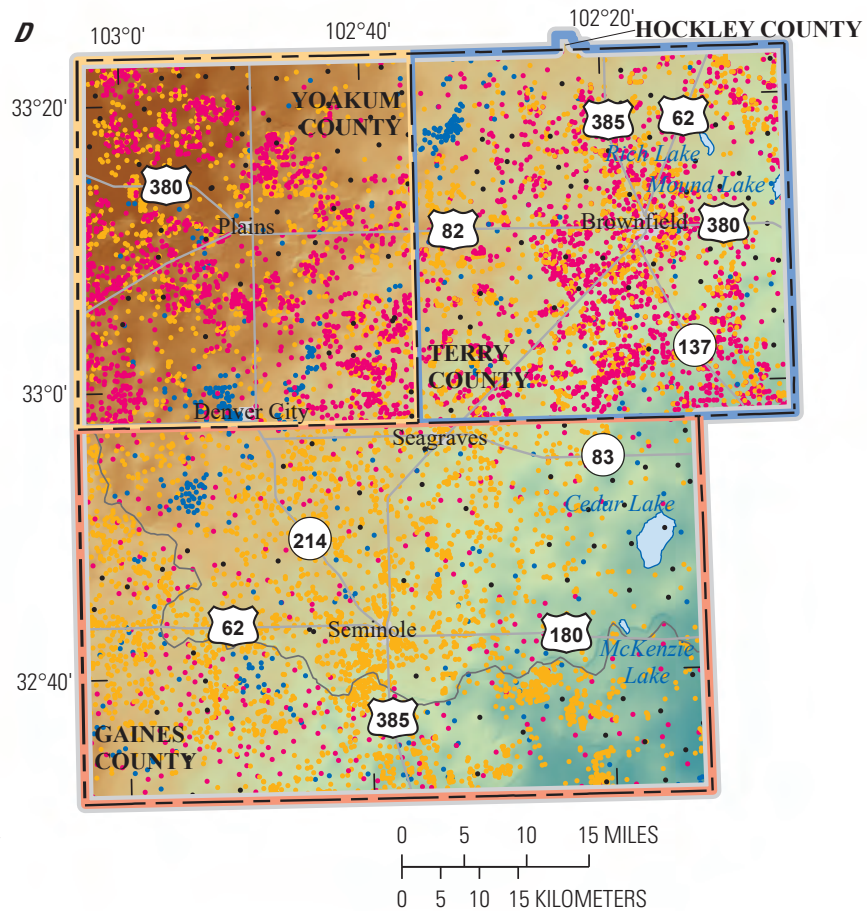

Figure 5. Revised (2020) hydrogeologic unit surfaces for $A$, the base (bottom) of the Dockum Group, $B$, the base of the Trinity Group, $C$, the base of the Fredericksburg Group, and $D$, the base of the Ogallala Formation in and near Gaines, Terry, and Yoakum Counties, Texas.-Continued 


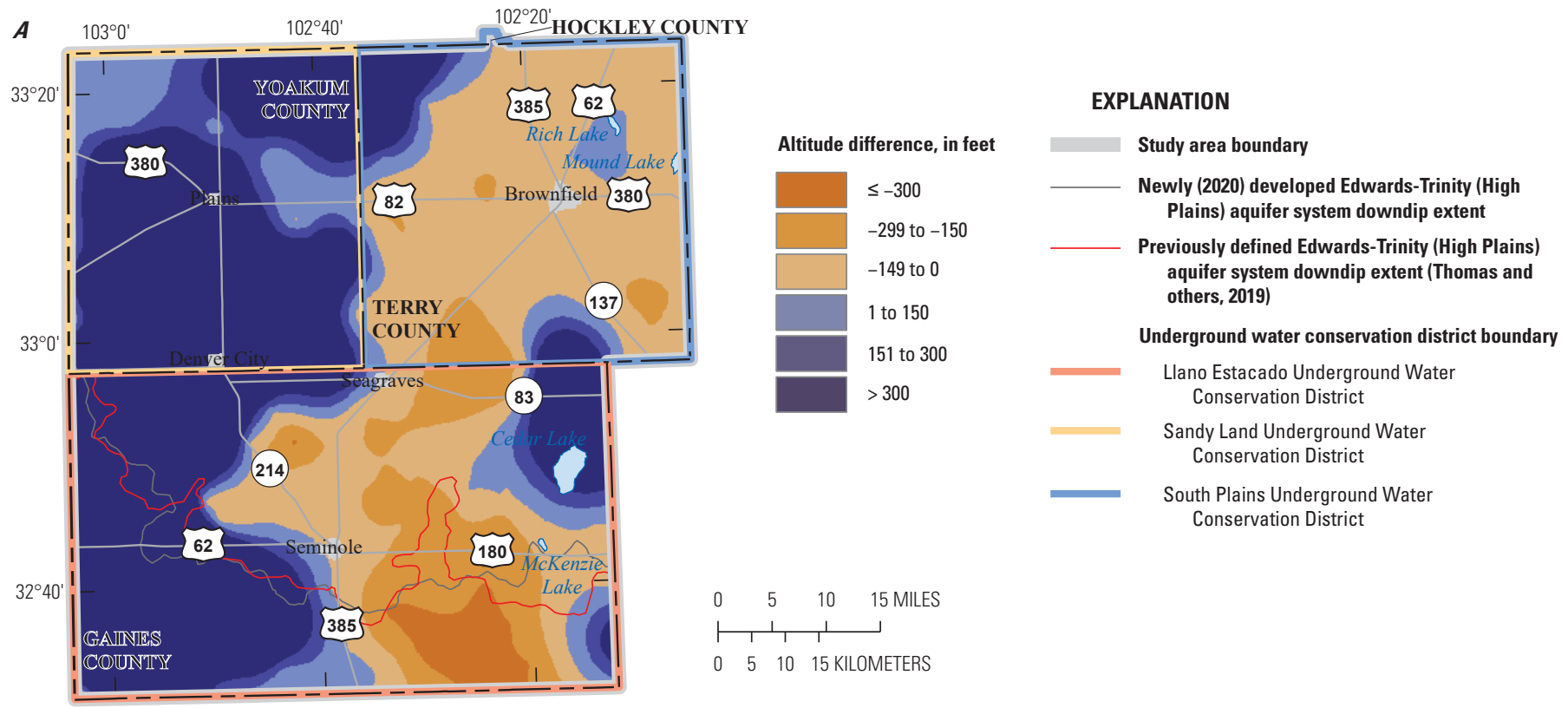

Base modified from U.S. Geological Survey 1:250,000-scale to 1:2,000,000-scale digital data, Universal Transverse Mercator projection, zone 13

North American Datum of 1983

Figure 6. Differences in mapped altitudes between the hydrogeologic unit surfaces from Thomas and others (2019) and the newly (2020) developed hydrogeologic unit surfaces for $A$, the base (bottom) of the Dockum Group, $B$, the base of the Trinity Group, $C$, the base of the Fredericksburg Group, and $D$, the base of the Ogallala Formation in and near Gaines, Terry, and Yoakum Counties, Texas. 


\section{EXPLANATION}

Altitude difference, in feet

\begin{tabular}{|l|l}
\hline & $\leq-50$ \\
\hline & -49 to -25 \\
& -24 to 0 \\
& 1 to 25 \\
& 26 to 50 \\
& $>50$
\end{tabular}

Study area boundary

Newly (2020) developed Edwards-Trinity (High Plains) aquifer system downdip extent

Previously defined Edwards-Trinity (High Plains) aquifer system downdip extent (Thomas and others, 2019)

Underground water conservation district boundary

Llano Estacado Underground Water Conservation District

Sandy Land Underground Water Conservation District

South Plains Underground Water Conservation District

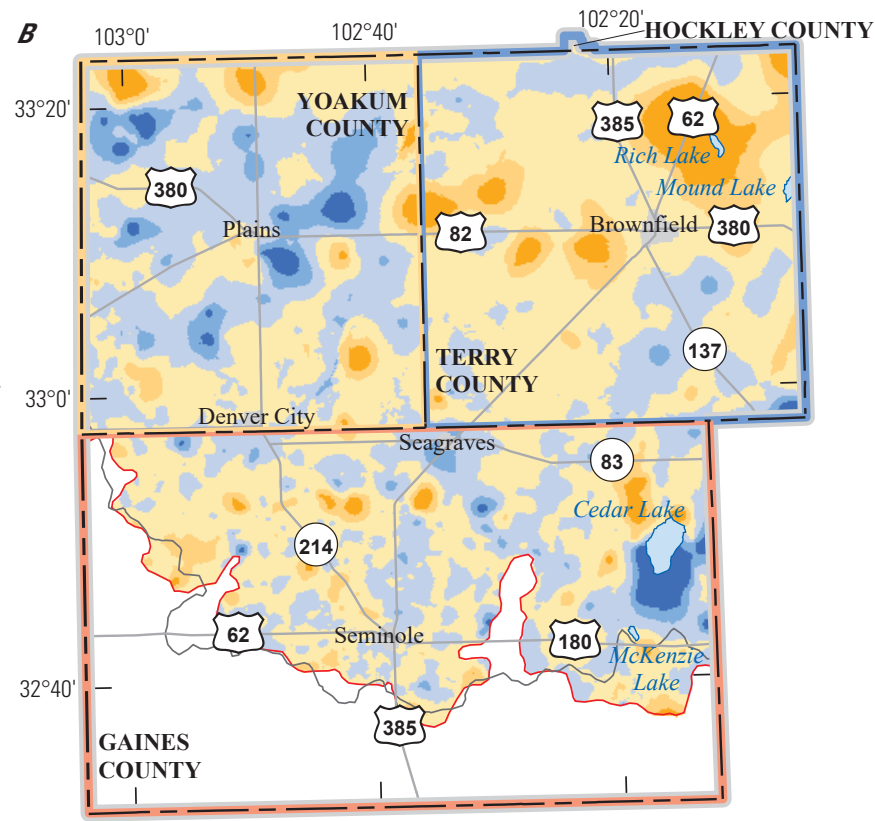

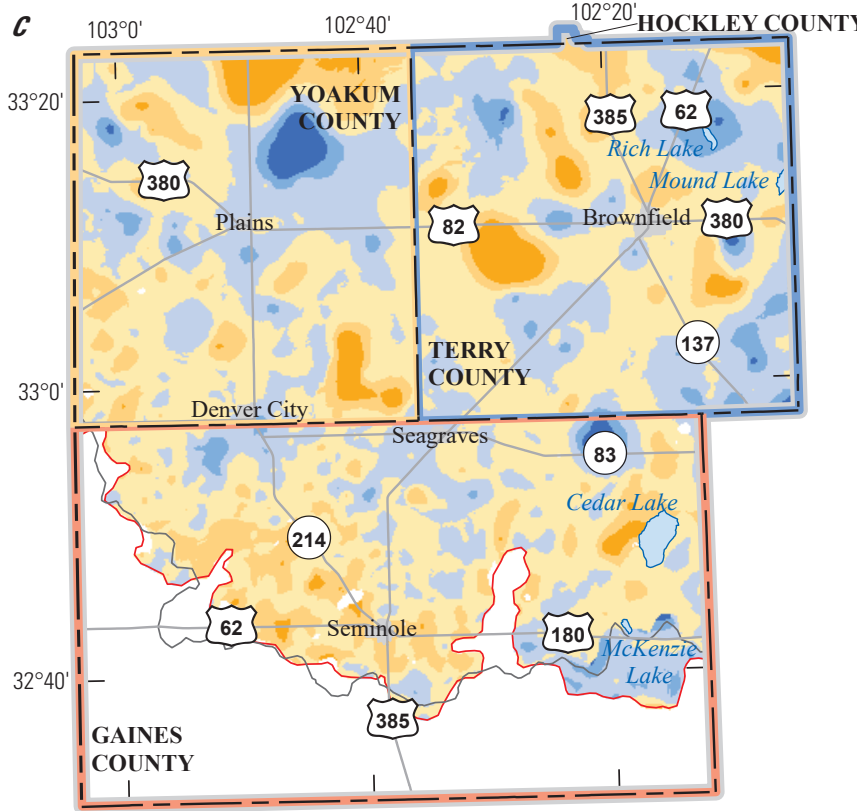

Base modified from U.S. Geological Survey 1:250,000-scale to 1:2,000,000-scale digital data Universal Transverse Mercator projection, zone 13 North American Datum of 1983

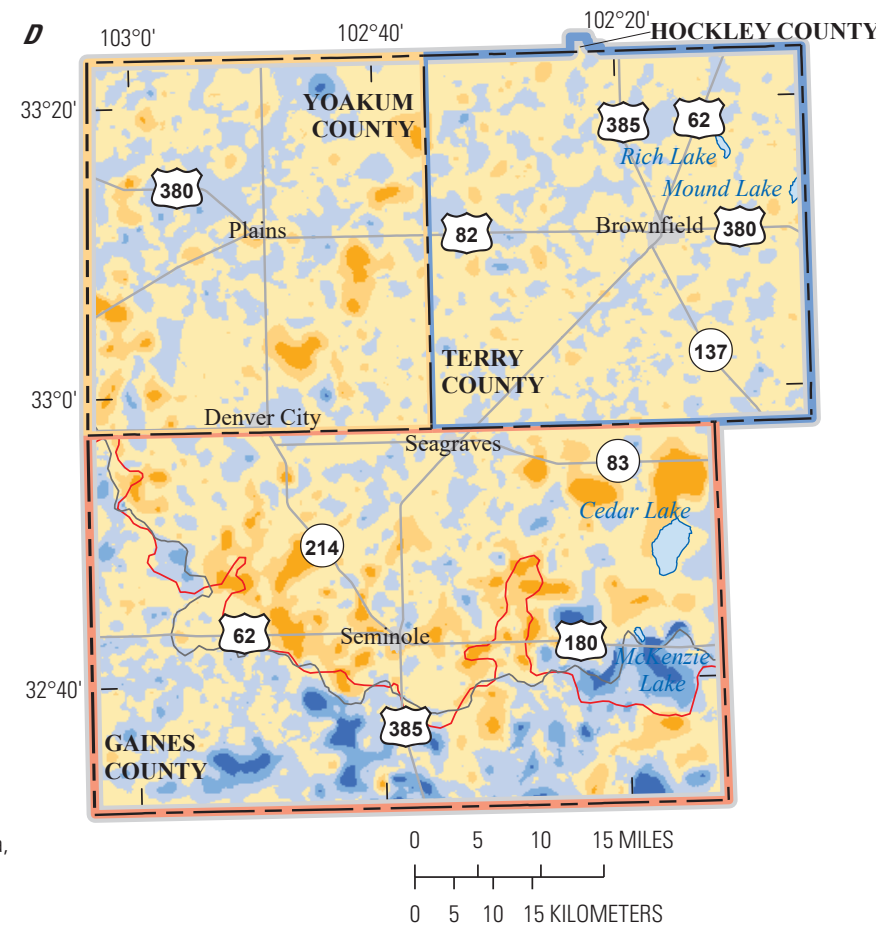

Figure 6. Differences in mapped altitudes between the hydrogeologic unit surfaces from Thomas and others (2019) and the newly (2020) developed hydrogeologic unit surfaces for $A$, the base (bottom) of the Dockum Group, $B$, the base of the Trinity Group, $C$, the base of the Fredericksburg Group, and $D$, the base of the Ogallala Formation in and near Gaines, Terry, and Yoakum Counties, Texas.Continued 

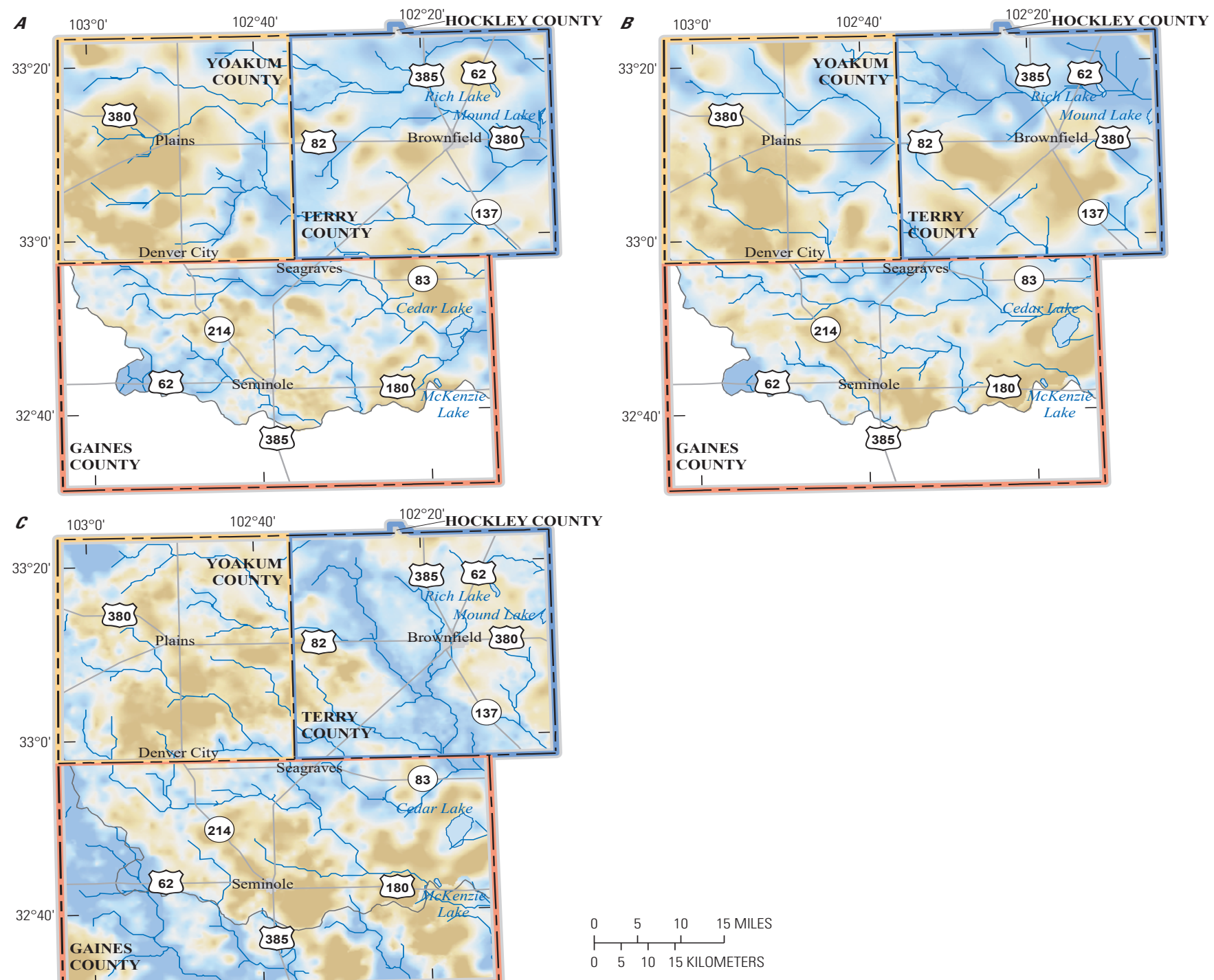

Base modified from U.S. Geological Survey 1:250,000-scale to 1:2,000,000-scale digital data Universal Transverse Mercator projection, zone 13

North American Datum of 1983

\section{EXPLANATION}
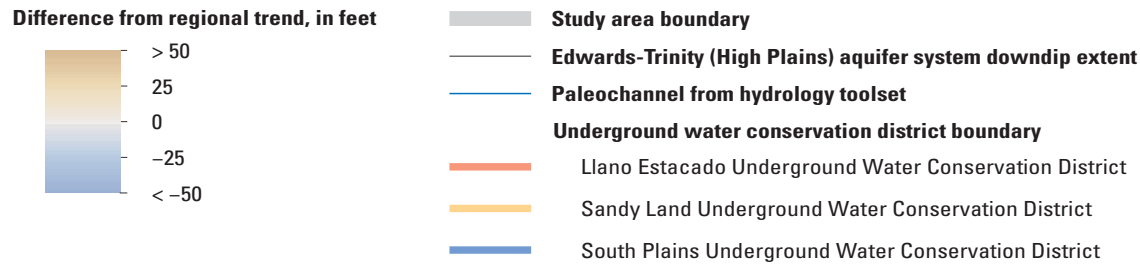

Figure 7. Results of trend-removal grids and hydrology toolset analysis used to identify paleochannel locations in the hydrogeologic unit surfaces for $A$, the base (bottom) of the Trinity Group, $B$, the base of the Fredericksburg Group, and $C$, the base of the 0 gallala Formation in and near Gaines, Terry, and Yoakum Counties, Texas. 
northwest corner of the study area (fig. $5 B$ ), and the lowest altitudes are in the southeast corner of the study area (fig. $5 D$ ). The Dockum Group has a dip direction of about 105 degrees from north with a dip angle of about 0.14 degrees, resulting in about $2.4 \mathrm{ft}$ of vertical change per 1,000 ft of horizontal distance.

Paleochannels eroded into the Dockum Group as represented by the bases of the Trinity Group and Ogallala Formation (where the Trinity Group is not present) generally have a west to east direction with some southerly direction in selected locations, as indicated by the low values from the trend-removal grids and from the potential paleochannel paths from the hydrology toolset analysis (fig. 7A; fig. 7C). Deep paleochannels were found in northern Terry County eroded into the Dockum Group (fig. 7A). Moderately deep paleochannels were found in the central part of the study area, which may provide possible pathway links (as shown by some of the stream paths from the hydrology toolset analysis) between deeper paleochannels.

The average thickness of the Dockum Group for the entire study area is $2,115 \mathrm{ft}$ (table 1). The total thickness of the Dockum Group ranges from 1,308 ft near the south-central part of the study area in Gaines County to $2,970 \mathrm{ft}$, west of Plains, Tex., in Yoakum County (table 1; fig. 8A). Even with the inclusion of new data in this phase of the study, there is a relatively small amount of data pertaining to the Dockum Group. Hydrogeologic data pertaining to the Dockum Group were available from 540 wells, representing about 2 percent of the more than 22,000 hydrogeologic records that were compiled. To better quantify the water content of the Dockum Group, additional data are needed to further define various layers, including the water-bearing sandstone layers of the Dockum Group and the viability of the unit as a water-supply resource for the area.

\section{Trinity Group}

The altitudes of the base of the Trinity Group range from about 2,830 ft to about 3,610 ft above NAVD 88 (fig. 5B). The altitudes of the top of the Trinity Group (the base of the Fredericksburg Group) range from about 2,880 $\mathrm{ft}$ to about $3,610 \mathrm{ft}$ above NAVD 88 (fig. 5C). The highest altitudes for both the base and top of the Trinity Group are in the northwest corner of the study area, and the lowest altitudes are along the eastern part of Gaines and Terry Counties. The dip direction is 105 and 110 degrees from north for the base and top of the Trinity Group, respectively. The base and top of the Trinity Group have the same dip angle of about 0.14 degrees, resulting in about 2.4 feet of vertical change per $1,000 \mathrm{ft}$ of horizontal distance.

Across most of the study area there was relatively minimal change in the depiction of the base of the Trinity Group and the top of the Trinity Group (the base of the Fredericksburg Group) from that previously reported in
Thomas and others (2019) (table 1). The base of the Trinity Group is shallower in most of Terry County and is greater than $25 \mathrm{ft}$ (deeper) in large parts of Yoakum County and to the east and south of Seminole, Tex. (fig. 6B). The top of the Trinity Group is less than -50 ft (shallower) in Terry and Yoakum Counties (fig. 6C). There are two areas where the top of the Trinity Group is greater than $50 \mathrm{ft}$ (deeper), about 10 miles northeast of Plains, Tex., and about 15 miles east of Seagraves, Tex.

Paleochannels eroded into the Trinity Group, as represented by the base of the Fredericksburg Group, generally have a west to east direction with some southerly direction in some locations, as indicated by the low values from the trend-removal grids and from the potential paleochannel paths from the hydrology toolset analysis (fig. 7B). Deep paleochannels are present in northern Terry County. Moderately deep paleochannels are present in the central part of the study area, which may provide possible pathway links (as shown by some of the potential paleochannel paths from the hydrology toolset analysis) between deeper paleochannels.

Although the Trinity Group is present throughout most of the northern parts of the study area, it thins to the south and is not present in the southern part of Gaines County (fig. 8B). The average unit thickness of the Trinity Group is $57 \mathrm{ft}$ (table 1). The Trinity Group is thickest in eastern Terry County about 10 miles southeast of Brownfield, Tex. (197 ft thick) (fig. 8B). Among the three counties that compose most of the study area (Gaines, Terry, and Yoakum Counties), the average thickness of the Trinity Group is the greatest in Terry County (77 ft thick) (table 1). The Trinity Group increases in thickness to the east starting near the Yoakum-Gaines County line, south of Plains, Tex., where it is about $50 \mathrm{ft}$ thick to near Brownfield where it is more than $190 \mathrm{ft}$ thick (fig. $8 B$ ).

\section{Fredericksburg Group}

The altitudes of the base of the Fredericksburg Group range from about $2,880 \mathrm{ft}$ to about $3,610 \mathrm{ft}$ above NAVD 88 (fig. 5C). The altitudes of the top of the Fredericksburg Group (base of the Ogallala Formation within the extent of the Trinity and Fredericksburg Groups, geologic units comprising the Edwards-Trinity [High Plains] aquifer) range from about $2,880 \mathrm{ft}$ to about $3,720 \mathrm{ft}$ above NAVD 88 (fig. $5 D$ ). The highest altitudes for the base and top of the Fredericksburg Group are in the northwest corner of the study area, and the lowest altitudes are along the eastern part of Gaines County and the eastern part of Terry County for the base. The dip direction is 110 and 125 degrees from north for the base and top of the Fredericksburg Group, respectively. The dip angle for both the top and base is about 0.14 degrees, resulting in about 2.4 feet of vertical change per $1,000 \mathrm{ft}$ of horizontal distance.

Across most of the study area there is relatively minimal change in the depiction of the base of the Fredericksburg Group and the top of the Fredericksburg Group (base of 


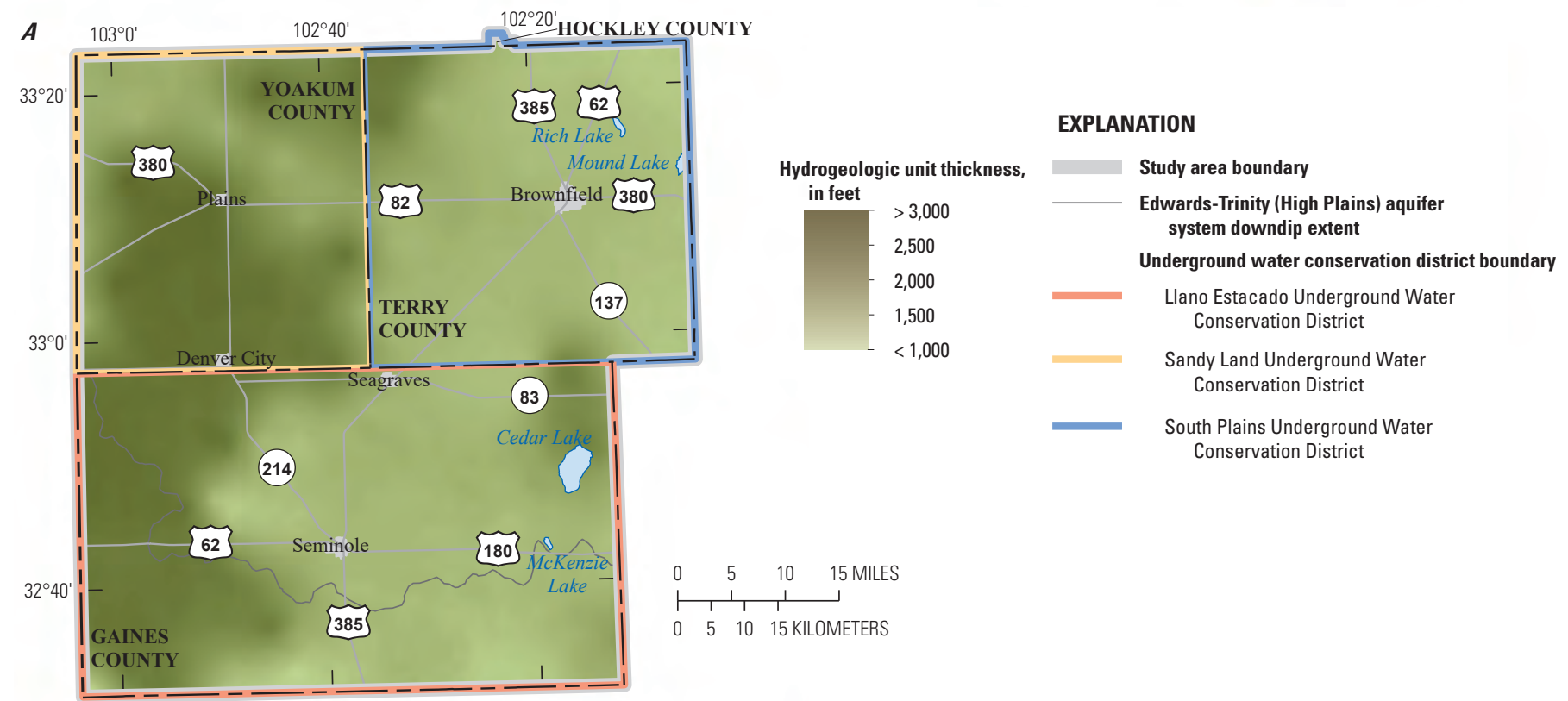

Base modified from U.S. Geological Survey 1:250,000-scale to 1:2,000,000-scale digital data,

Universal Transverse Mercator projection, zone 13

North American Datum of 1983

Figure 8. Hydrogeologic unit thickness of $A$, the Dockum Group, $B$, the Trinity Group, $C$, the Fredericksburg Group, and $D$, the Ogallala Formation in and near Gaines, Terry, and Yoakum Counties, Texas. 


\section{EXPLANATION}

Hydrogeologic unit thickness, in feet

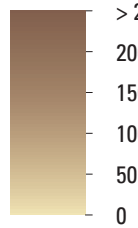

Study area boundary

Edwards-Trinity (High Plains) aquife system downdip extent

Underground water conservation district boundary

Llano Estacado Underground Water Conservation District

Sandy Land Underground Water Conservation District

South Plains Underground Water Conservation District

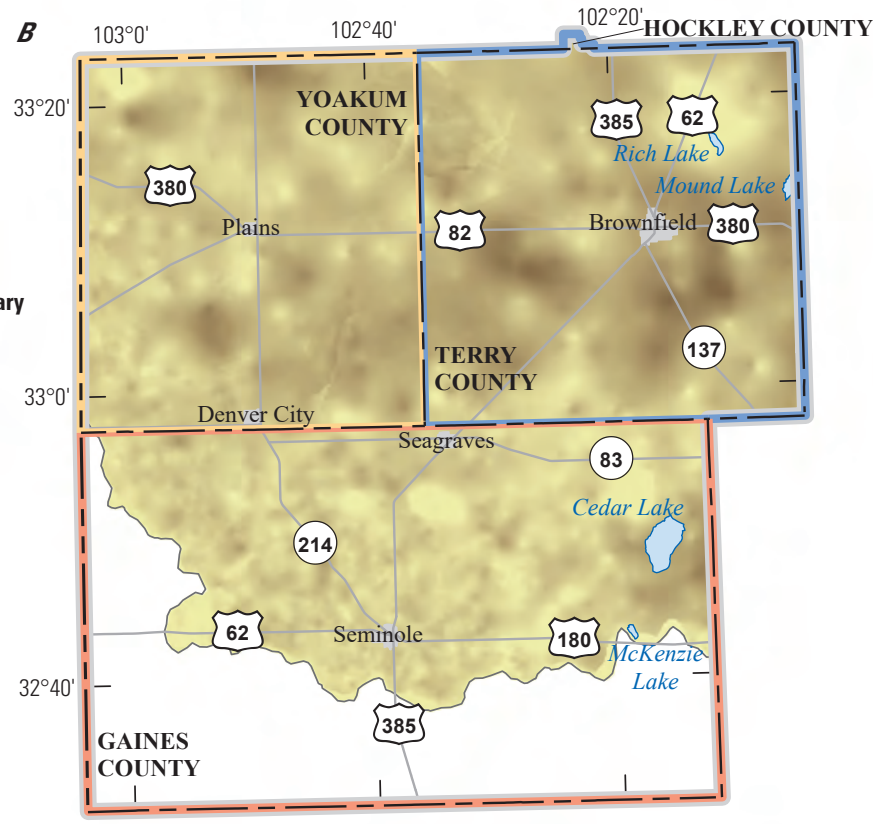

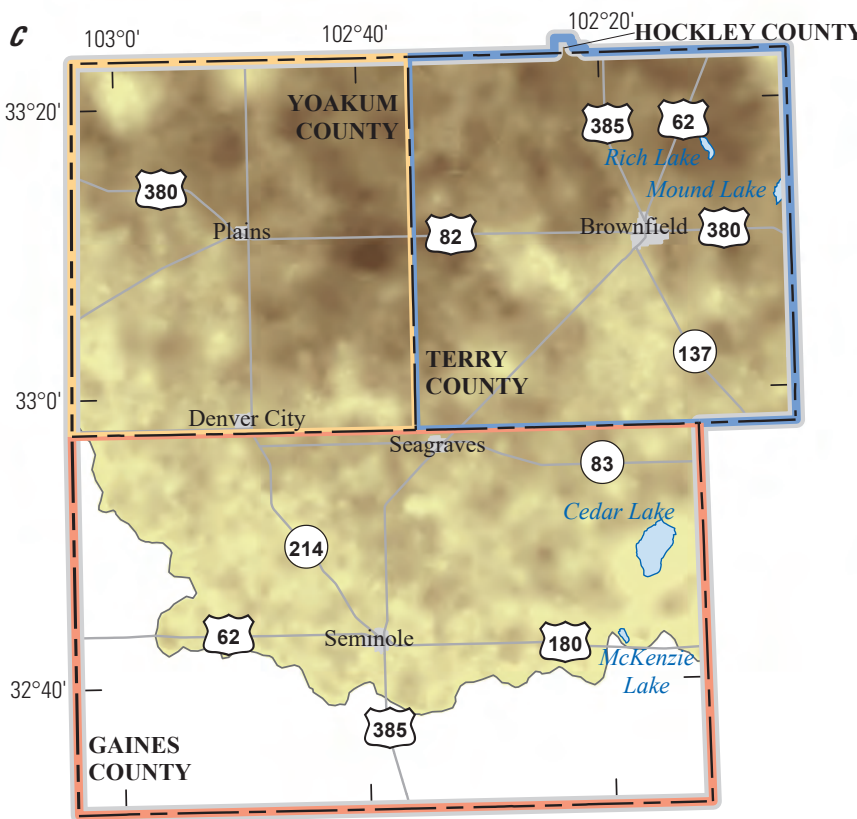

Base modified from U.S. Geological Survey 1:250,000-scale to 1:2,000,000-scale digital data, Universal Transverse Mercator projection, zone 13

North American Datum of 1983

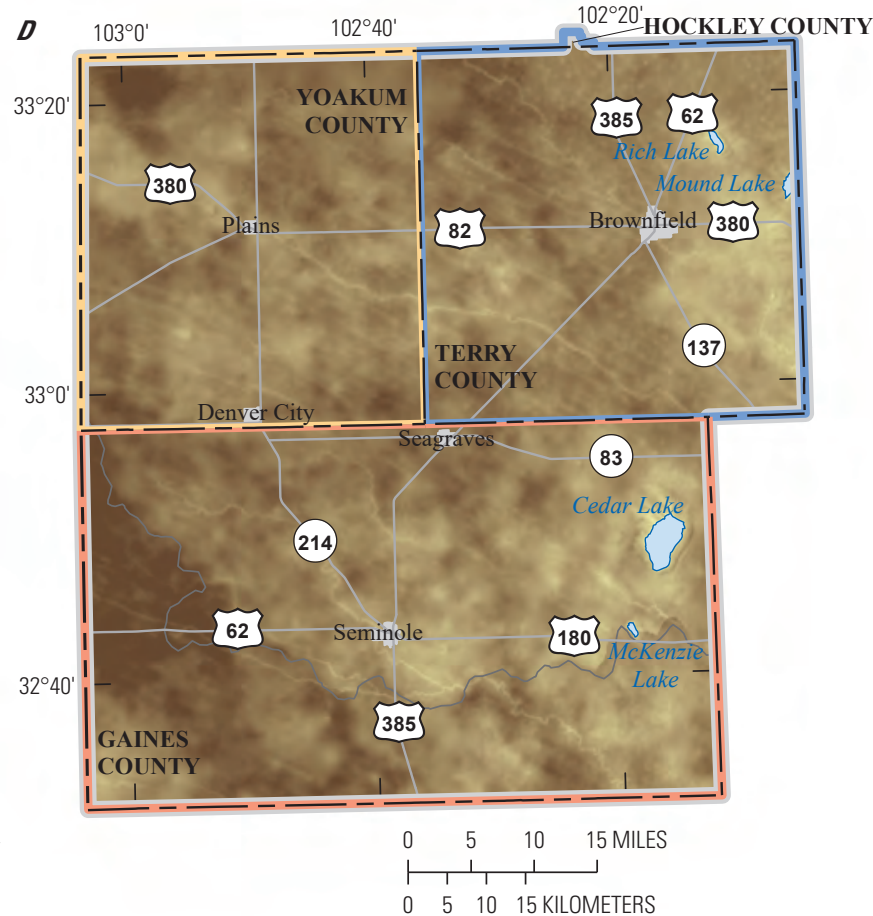

Figure 8. Hydrogeologic unit thickness of $A$, the Dockum Group, $B$, the Trinity Group, $C$, the Fredericksburg Group, and $D$, the Ogallala Formation in and near Gaines, Terry, and Yoakum Counties, Texas.-Continued 
the Ogallala Formation within the extent of the Trinity and Fredericksburg Groups (geologic units comprising the Edwards-Trinity [High Plains] aquifer) from that previously reported in Thomas and others (2019). The base of the Fredericksburg Group is less than $-50 \mathrm{ft}$ shallower in Terry and Yoakum Counties than previously reported (fig. 6C). The base of the Fredericksburg Group is more than $50 \mathrm{ft}$ deeper than previously identified in two areas, about 10 miles northeast of Plains, Tex., and about 15 miles east of Seagraves, Tex. Most of the locations where the top of the Fredericksburg Group is shallower than previously reported are generally near the southern extent of the Trinity and Fredericksburg Groups (geologic units comprising the Edwards-Trinity [High Plains] aquifer) (fig. 6D). The erosional features (one 10 miles east of Seminole, Tex., and the other 15 miles west of Seminole, Tex.) defined by Thomas and others (2019) were removed in response to insights provided by the expanded dataset such that points with existing Fredericksburg Group contacts were included in the analysis at these locations. The inclusion of these points resulted in more constraint to match the altitudes of the Fredericksburg Group on either side of the erosional features, causing the Ogallala Formation to be shallower in these features.

Paleochannels eroded into the Fredericksburg Group, as represented by the base of the Ogallala Formation within the extent of the Trinity and Fredericksburg Groups (geologic units comprising the Edwards-Trinity [High Plains] aquifer), have a northwest to southeast direction as indicated by the low values from the trend-removal grids and from the potential paleochannel paths from the hydrology toolset analysis (fig. 7C). A paleochannel was found within Terry County beginning near the northwest border of the county and traversing to the northeast border of Gaines County (fig. 7C). Moderately deep paleochannels were found in the central part of the study area that may provide possible pathway links (as shown by some of the potential paleochannel paths from the hydrology toolset analysis) between deeper paleochannels.

Although the Fredericksburg Group is present throughout most of the northern parts of the study area, it thins to the south and is not present in the southern part of Gaines County (fig. 8C). The average unit thickness of the Fredericksburg Group is $84 \mathrm{ft}$ (table 1). The thickness of the Fredericksburg Group (table 1; fig. $8 C$ ) is more variable than the thickness of the Trinity Group (table 1; fig. 8B). The Fredericksburg Group is thickest in the north-central part of the study area in between Plains and Brownfield, Tex. (280 ft thick) (fig. 8C). Among the three counties that compose most of the study area (Gaines, Terry, and Yoakum Counties), the average thickness of the Fredericksburg Group is the greatest in Terry County (108 ft thick) (table 1).

\section{Ogallala Formation}

The altitudes of the base of the Ogallala Formation range from about $2,790 \mathrm{ft}$ to about $3,720 \mathrm{ft}$ above NAVD 88 (fig. $5 D$ ). The altitudes of the top of the Ogallala Formation range from about $2,930 \mathrm{ft}$ to about $3,900 \mathrm{ft}$ above NAVD 88 (fig. 2), and the formation crops out in much of the study area. For the base and top of the Ogallala Formation, the highest altitudes are in the northwest corner of the study area, and the lowest altitudes are in the southeast corner of the study area. The dip direction for the base of the Ogallala Formation is about 125 degrees from north with a dip angle of about 0.14 degrees, resulting in about $2.4 \mathrm{ft}$ of vertical change per $1,000 \mathrm{ft}$ of horizontal distance. The dip direction for the top of the Ogallala Formation is about 120 degrees from north with a dip angle of about 0.15 degrees, resulting in about $2.6 \mathrm{ft}$ of vertical change per $1,000 \mathrm{ft}$ of horizontal distance.

Across most of the study area there is relatively minimal change in the depiction of the base of the Ogallala Formation from that previously reported in Thomas and others (2019) (table 1; fig. 6D). Most of the locations where the base of the Ogallala Formation is shallower than previously reported are in the southern part of the study area, specifically, in areas where the Ogallala Formation overlies the southern extent of the Trinity and Fredericksburg Groups (geologic units comprising the Edwards-Trinity [High Plains] aquifer); the base of the Ogallala Formation deepened south of the extent (fig. 6D). The deeper base of the Ogallala Formation is a result of redefining the base to include the isolated parts of the Trinity and Fredericksburg Groups. Effectively, in these areas, the Ogallala Formation is a composition of the eroded remnants of the Trinity and Fredericksburg Groups and Ogallala Formation. Because of the complexity of the hydrogeologic extents of the isolated parts of Trinity and Fredericksburg Groups, for the purpose of this report, they were included together with the Ogallala Formation.

Paleochannels eroded into the Dockum (where the Fredericksburg Group is not present) and Fredericksburg Groups, as represented collectively by the base of the Ogallala Formation, generally have a northwest to southeast direction, as indicated by the low values from the trend-removal grids and from the potential paleochannel paths from the hydrology toolset analysis (fig. 7C). A paleochannel was found in the southwest corner of the study area, beginning near the northwest border of Gaines County and traversing southeast to the south border of Gaines County south of Seminole, Tex. Another paleochannel was found within Terry County beginning near the northwest border of the county and traversing to the northeast border of Gaines County. Moderately deep paleochannels were found in the central part of the study area that may provide possible pathway links (as shown by some of the potential paleochannel paths from the hydrology toolset analysis) between deeper paleochannels.

The refinement of the base of the Ogallala Formation did not result in a substantial change in the final thickness statistics across the study area. The total unit thickness of the Ogallala Formation ranges from $20 \mathrm{ft}$ to $302 \mathrm{ft}$ (table 1), with an average thickness of $154 \mathrm{ft}$ (Payne and others, 2020), whereas the average thickness reported in Thomas and others (2019) is $165 \mathrm{ft}$. In general, the thickest parts of the Ogallala Formation are in western Gaines County and the northwest 
corners of Yoakum and Terry Counties (fig. 8D); the thinnest parts are in the eastern part of the study area and southeast of Seminole, Tex. Localized areas where the Ogallala Formation is relatively thin are present in some low-lying areas (for example, near Cedar Lake, Mound Lake, and Rich Lake).

\section{Geochemistry}

The geochemical methods and procedures presented in the "Sample Collection and Analysis" and "Quality-Assurance and Quality-Control Procedures" sections of this report have been described previously (Teeple, 2017). Additional information relevant to the current study (such as matrix spike comparisons) is discussed. These sections have been included in this report to document the sample collection and analysis methods and the quality-assurance and quality control procedures used to collect, analyze, and verify the data used in this report.

\section{Sample Collection and Analysis}

A total of 51 groundwater samples were collected in Gaines, Terry, and Yoakum Counties in Texas to assess groundwater quality conditions (fig. 3, table 2). In July and August 2014, 20 wells in Terry County and one well in Gaines County were sampled, whereas in July 2016, 10 wells in Gaines County and 20 wells in Yoakum County were sampled. Wells sampled were completed in either the Ogallala, Edwards-Trinity (High Plains), Dockum, or a mix of those aquifers. Physicochemical properties ( $\mathrm{pH}$, specific conductance, dissolved oxygen, water temperature, turbidity, and alkalinity) along with barometric pressure, groundwater pumping rates, and depth to water were measured in the field during sample collection. Samples were collected and shipped for laboratory analyses of major ions, trace elements, nutrients, organic compounds, strontium-87/strontium- 86 isotopic ratio $\left({ }^{87} \mathrm{Sr} / 86 \mathrm{Sr}\right)$, hydrogen-2/hydrogen-1 isotopic ratio $(\delta \mathrm{D})$, oxygen-18/oxygen-16 isotopic ratio $\left(\delta^{18} \mathrm{O}\right)$, tritium $\left({ }^{3} \mathrm{H}\right)$, and carbon-14 $\left({ }^{14} \mathrm{C}\right)$. All water-quality results were reviewed for completeness and accuracy and stored in the National Water Information System (NWIS) (U.S. Geological Survey, 2020b).

\section{Field Procedures}

The field procedures used to collect most groundwater samples are described in the USGS "National Field Manual for the Collection of Water-Quality Data" (U.S. Geological Survey, variously dated). Samples for isotope analyses were collected in accordance with procedures from the USGS Reston Groundwater Dating Laboratory in Reston, Virginia. (U.S. Geological Survey, 2012a), and the USGS Reston Stable Isotope Laboratory in Reston, Va. (U.S. Geological Survey, 2012b). Groundwater-level measurements were made prior to pumping each well by using an electric or steel tape and following methods described in Cunningham and Schalk (2011). Prior to sample collection, each well usually was pumped to purge three casing volumes of water. The number of casing volumes that were purged depended on depth of the well, well-casing diameter, and the frequency of pumping performed at the well. After the necessary casing volumes were purged, the wells were pumped continually until steadystate measurements for all the physicochemical properties were obtained to ensure representative samples of the water in the aquifer were collected (U.S. Geological Survey, variously dated). When steady-state measurements indicating the system had reached equilibrium were obtained, water samples were collected from the well through fluoropolymer tubing and stored in new, precleaned bottles. Samples were collected prior to well water entering pressure tanks and prior to being filtered or undergoing other forms of treatment. Samples were processed onsite according to each laboratory's protocols to minimize chemical changes or contamination. In addition, samples were preserved by adding the appropriate acid (when necessary), chilled to 4 degrees Celsius $\left({ }^{\circ} \mathrm{C}\right)$ (when necessary), or both before being shipped to the laboratory for analysis. Time-sensitive samples were shipped overnight to the analyzing laboratories, and the remaining samples were shipped to analyzing laboratories upon return from the field. After sample collection and processing, the sampling equipment was cleaned according to the established protocols prior to use at the next well scheduled for sampling (Wilde, 2004).

\section{Analytical Methods}

Major ions, trace elements, nutrients, and organic compounds were analyzed by the USGS National Water Quality Laboratory (NWQL), Denver, Colorado, using published methods. Analytical methods for major ions are published in Fishman and Friedman (1989), Fishman (1993), and American Public Health Association (1998). Trace-element analytical methods are published in Fishman and Friedman (1989), Garbarino (1999), and Garbarino and others (2006). Nutrients analytical methods are published in Fishman (1993) and Patton and Kryskalla (2003). Organic compounds analysis methods are published in Zaugg and others (1995), Lindley and others (1996), Sandstrom and others (2001), and Madsen and others (2003).

\section{Environmental Tracers}

Environmental tracers, such as ${ }^{87} \mathrm{Sr} / 86 \mathrm{Sr}, \delta \mathrm{D}, \delta^{18} \mathrm{O},{ }^{3} \mathrm{H}$, and ${ }^{14} \mathrm{C}$ concentrations in groundwater, are useful for understanding where and when groundwater recharge occurred in an aquifer system. ${ }^{87} \mathrm{Sr} /{ }^{86} \mathrm{Sr}$ isotopic ratios can be a useful tool for determining the source of dissolved constituents in groundwater; the isotopes were analyzed at the Menlo Park Isotope Laboratory in Menlo Park, California, in accordance with methods described by Kendall and McDonnell (1998). $\delta \mathrm{D}$ and $\delta^{18} \mathrm{O}$ are useful indicators of conditions at the time 
Table 2. Selected well completion information, aquifer designation, and sampling date for groundwater-quality samples collected from wells in and near Gaines, Terry, and Yoakum Counties, Texas.

[USGS, U.S. Geological Survey; bls, below land surface; OGLL, High Plains aquifer system (Ogallala aquifer); ETHP; Edwards-Trinity (High Plains) aquifer system; DOCK, Dockum aquifer; COMB, Combination; --, no value]

\begin{tabular}{|c|c|c|c|c|c|c|c|}
\hline $\begin{array}{c}\text { Site } \\
\text { identifier } \\
\text { (fig. 3) }\end{array}$ & USGS well number & County & $\begin{array}{c}\text { Well } \\
\text { depth } \\
\text { (feet bls) }\end{array}$ & $\begin{array}{c}\text { Screened or } \\
\text { open interval } \\
\text { (feet bls) }\end{array}$ & $\begin{array}{c}\text { Aquifer in } \\
\text { which the well } \\
\text { is completed }\end{array}$ & $\begin{array}{c}\text { Aquifer } \\
\text { designation }\end{array}$ & Sampling date \\
\hline 01500 & 324401102163401 & Gaines & 110 & $96-110$ & ETHP & ETHP & $7 / 19 / 2016$ \\
\hline 03060 & 325046102221001 & Gaines & 60 & -- & OGLL & OGLL & $7 / 19 / 2016$ \\
\hline 04518 & 330351102130301 & Terry & 90 & $50-90$ & OGLL; ETHP & COMB & $7 / 30 / 2014$ \\
\hline 04809 & 330624102091701 & Terry & 275 & $235-275$ & ETHP & ЕTHP & $8 / 2 / 2014$ \\
\hline 05380 & 330852102130401 & Terry & 53 & $23-53$ & OGLL & OGLL & $7 / 30 / 2014$ \\
\hline 06260 & 330129102180701 & Terry & 157 & $0-157$ & OGLL & OGLL & $8 / 1 / 2014$ \\
\hline 07706 & 331131102133701 & Terry & -- & -- & OGLL & OGLL & $8 / 1 / 2014$ \\
\hline 08389 & 331657102131801 & Terry & 80 & $40-80$ & OGLL & OGLL & $8 / 4 / 2014$ \\
\hline 08956 & 330618102190801 & Terry & 165 & $125-165$ & OGLL & OGLL & $7 / 29 / 2014$ \\
\hline 09493 & 332014102100101 & Terry & 147 & $107-147$ & OGLL & OGLL & $7 / 31 / 2014$ \\
\hline 09503 & 324911102310901 & Gaines & 190 & $150-190$ & OGLL; ETHP & COMB & $7 / 19 / 2016$ \\
\hline 09781 & 323339102431001 & Gaines & 160 & -- & OGLL & OGLL & $7 / 21 / 2016$ \\
\hline 10061 & 331802102535902 & Yoakum & 155 & -- & ETHP & ETHP & $7 / 29 / 2016$ \\
\hline 10509 & 332013103001501 & Yoakum & 220 & -- & OGLL & OGLL & $7 / 29 / 2016$ \\
\hline 10523 & 330817103025002 & Yoakum & 160 & $92-159$ & OGLL & OGLL & $7 / 29 / 2016$ \\
\hline 10639 & 325505102562201 & Gaines & 100 & -- & OGLL & OGLL & $7 / 20 / 2016$ \\
\hline 10676 & 325933102501701 & Yoakum & 137 & $87-137$ & OGLL & OGLL & $7 / 26 / 2016$ \\
\hline 10748 & 325731102311201 & Gaines & 380 & $308-380$ & ETHP & ETHP & $8 / 6 / 2014$ \\
\hline 11642 & 330036102071701 & Terry & 250 & $210-250$ & ETHP; DOCK & COMB & $8 / 4 / 2014$ \\
\hline 11771 & 331045102133901 & Terry & 340 & $\begin{array}{c}80-100 \\
300-340\end{array}$ & OGLL; ETHP & COMB & $8 / 1 / 2014$ \\
\hline 12504 & 330904102292501 & Terry & 113 & -- & ETHP & ETHP & $8 / 6 / 2014$ \\
\hline 12514 & 331305102122401 & Terry & 100 & $60-100$ & OGLL & OGLL & $8 / 5 / 2014$ \\
\hline 14388 & 330339102235001 & Terry & 172 & $100-172$ & OGLL & OGLL & $8 / 4 / 2014$ \\
\hline 15747 & 331316102195401 & Terry & 420 & $\begin{array}{l}100-140 \\
300-420\end{array}$ & ETHP & ETHP & $8 / 6 / 2014$ \\
\hline 18745 & 331029102272001 & Terry & 145 & $105-145$ & OGLL & OGLL & $8 / 2 / 2014$ \\
\hline 18790 & 331646102220901 & Terry & 170 & $110-170$ & OGLL; ETHP & COMB & $8 / 2 / 2014$ \\
\hline 19639 & 324324102483201 & Gaines & 80 & -- & OGLL & OGLL & $7 / 20 / 2016$ \\
\hline 20215 & 325053102424201 & Gaines & 360 & -- & DOCK & DOCK & $7 / 20 / 2016$ \\
\hline 20759 & 331755102211401 & Terry & 159 & $0-159$ & OGLL & OGLL & $7 / 30 / 2014$ \\
\hline 20903 & 330639102371201 & Yoakum & 65 & $45-65$ & OGLL; ETHP & COMB & $7 / 26 / 2016$ \\
\hline 21325 & 324610102501401 & Gaines & 240 & $195-235$ & ETHP & ЕTHP & $7 / 21 / 2016$ \\
\hline 21524 & 330751102351501 & Terry & 110 & $80-110$ & OGLL; ETHP & COMB & $7 / 29 / 2014$ \\
\hline 23705 & 332054102262101 & Terry & -- & -- & OGLL & OGLL & $8 / 5 / 2014$ \\
\hline 24005 & 331359102351201 & Terry & 161 & $0-161$ & OGLL & OGLL & $7 / 31 / 2014$ \\
\hline 24915 & 330232102432301 & Yoakum & 161 & $110-161$ & OGLL & OGLL & $7 / 26 / 2016$ \\
\hline 25208 & 325848102503501 & Yoakum & 255 & -- & DOCK & DOCK & $7 / 27 / 2016$ \\
\hline 25317 & 324040103010001 & Gaines & 242 & $180-242$ & OGLL & OGLL & $7 / 21 / 2016$ \\
\hline
\end{tabular}


Table 2. Selected well completion information, aquifer designation, and sampling date for groundwater-quality samples collected from wells in and near Gaines, Terry, and Yoakum Counties, Texas.-Continued

[USGS, U.S. Geological Survey; bls, below land surface; OGLL, High Plains aquifer system (Ogallala aquifer); ETHP; Edwards-Trinity (High Plains) aquifer system; DOCK, Dockum aquifer; COMB, Combination; --, no value]

\begin{tabular}{cclccccc}
\hline $\begin{array}{c}\text { Site } \\
\text { identifier } \\
\text { (fig. 3) }\end{array}$ & USGS well number & County & $\begin{array}{c}\text { Well } \\
\text { depth } \\
\text { (feet bls) }\end{array}$ & $\begin{array}{c}\text { Screened or } \\
\text { open interval } \\
\text { (feet bls) }\end{array}$ & $\begin{array}{c}\text { Aquifer in } \\
\text { which the well } \\
\text { is completed }\end{array}$ & $\begin{array}{c}\text { Aquifer } \\
\text { designation }\end{array}$ & Sampling date \\
\hline 25644 & 325540102541901 & Gaines & 2,150 & $\begin{array}{c}1,858-1,930, \\
1,933-1,940, \\
1,944-1,984\end{array}$ & DOCK & DOCK & $7 / 22 / 2016$ \\
& & & & & & & \\
25865 & 331438102392001 & Yoakum & 180 & -- & ETHP & ETHP & $7 / 27 / 2016$ \\
25883 & 331100102391301 & Yoakum & 175 & $125-175$ & OGLL & OGLL & $7 / 25 / 2016$ \\
26458 & 330227102485401 & Yoakum & 300 & -- & ETHP & ETHP & $7 / 24 / 2016$ \\
26701 & 330235102502001 & Yoakum & 250 & -- & DOCK & DOCK & $7 / 27 / 2016$ \\
27256 & 330559102482101 & Yoakum & 154 & -- & ETHP & ETHP & $7 / 25 / 2016$ \\
27272 & 331248102430301 & Yoakum & 210 & $150-210$ & OGLL & OGLL & $7 / 25 / 2016$ \\
27287 & 330209102565201 & Yoakum & 235 & -- & DOCK & DOCK & $7 / 24 / 2016$ \\
27488 & 332134102414901 & Yoakum & 150 & $110-150$ & OGLL & OGLL & $7 / 28 / 2016$ \\
27727 & 325929102570201 & Yoakum & 260 & -- & ETHP & ETHP & $7 / 24 / 2016$ \\
27811 & 331238102533401 & Yoakum & 57 & -- & OGLL & OGLL & $7 / 22 / 2016$ \\
27974 & 325923103010101 & Yoakum & 321 & $201-321$ & OGLL; ETHP & COMB & $7 / 29 / 2016$ \\
28275 & 331335102492001 & Yoakum & 235 & $165-235$ & ETHP & ETHP & $7 / 28 / 2016$ \\
28367 & 330809102581901 & Yoakum & 200 & $120-200$ & OGLL & OGLL & $7 / 22 / 2016$ \\
\hline
\end{tabular}

and place of groundwater recharge and were analyzed at the USGS Stable Isotope Laboratory in Reston, Va. $\delta \mathrm{D}$ analytical methods are described in Révész and Coplen (2008a), and $\delta^{18} \mathrm{O}$ analytical methods are described in Révész and Coplen (2008b). ${ }^{3} \mathrm{H}$ and ${ }^{14} \mathrm{C}$ can provide information on the apparent age of the groundwater. ${ }^{3} \mathrm{H}$ was analyzed at the Menlo Park Tritium Laboratory in Menlo Park, Calif. Analytical methods for ${ }^{3} \mathrm{H}$ are documented in Östlund and Werner (1962) and Thatcher and others (1977). ${ }^{14} \mathrm{C}$ was analyzed at the National Ocean Sciences Accelerator Mass Spectrometry Facility at the Woods Hole Oceanographic Institution in Woods Hole, Massachusetts (Woods Hole Oceanographic Institution, 2020). ${ }^{14} \mathrm{C}$ was analyzed by accelerator mass spectrometry (AMS). Methods for analyzing AMS results are described by Roberts and others (2010) and are reported in the standard ${ }^{14} \mathrm{C}$ format (Stuiver and Polach, 1977). Methods for determining and reporting ${ }^{14} \mathrm{C}$ ages are described in Karlen and others (1964), Olsson and Klasson (1970), Stuiver and Polach (1977), and Stuiver (1980).

\section{Strontium Isotopic Ratios}

Strontium isotope ratios, specifically ${ }^{87} \mathrm{Sr} / 86 \mathrm{Sr}$, are useful in describing the source of water as defined by changes in the composition of the salts dissolved in the water (Kendall and McDonnell, 1998). When ${ }^{87} \mathrm{Sr} / 86 \mathrm{Sr}$ values increase or decrease from one location to the next along a flow path, mixing of geochemically different sources of water or mixing of water from different aquifer units could be occurring. Strontium can substitute for calcium especially in carbonate rocks that are commonly found in subsurface geologic units in the study area (Hem, 1985; Banner, 2004; Musgrove and others, 2010; Bumgarner and others, 2012). As a result of this rock-water interaction, ${ }^{87} \mathrm{Sr} /{ }^{86} \mathrm{Sr}$ values can be used to evaluate sources of dissolved constituents to groundwater and to determine possible groundwater mixing (McNutt and others, 1990; Musgrove and Banner, 1993; Banner and others, 1994; Uliana and others, 2007; Musgrove and others, 2010). Water in specific geologic units is expected to have ${ }^{87} \mathrm{Sr} / 86 \mathrm{Sr}$ values that reflect the isotopic ratio of minerals in that specific unit; therefore, ${ }^{87} \mathrm{Sr} / 86 \mathrm{Sr}$ values can be used as a geochemical tracer of source waters originating from different geologic units (Kendall and McDonnell, 1998). By using ${ }^{87} \mathrm{Sr} / 86 \mathrm{Sr}$ values obtained from previous studies such as McMahon and others (2004) and Bumgarner and others (2012), ${ }^{87} \mathrm{Sr} /{ }^{86} \mathrm{Sr}$ values measured in groundwater samples from Gaines, Terry, and Yoakum Counties can be compared to ${ }^{87} \mathrm{Sr} / 86 \mathrm{Sr}$ values in water samples collected from various aquifers within the study area, such as the Ogallala, Edwards-Trinity (High Plains), and Dockum aquifers.

\section{Hydrogen and Oxygen Isotopic Ratios}

Ratios of the stable isotopes of the water molecule (hydrogen and oxygen) can yield isotopic signatures that are useful indicators of the regional recharge regimes of a hydrogeologic system (Faure, 1986). Plotting the relation between 
$\delta \mathrm{D}$ and $\delta^{18} \mathrm{O}$ can aid in analyzing the time and place that surface water or precipitation initially recharged the groundwater system; $\delta \mathrm{D}$ and $\delta^{18} \mathrm{O}$ are measured in units of per mil (Faure, 1986; Uliana and others, 2007; Bumgarner and others, 2012). Craig (1961) used $\delta \mathrm{D}$ and $\delta^{18} \mathrm{O}$ isotopic analyses from multiple precipitation samples collected around the world to create a Global Meteoric Water Line (GMWL), a linear regression line computed as $\delta \mathrm{D}=8 \times \delta^{18} \mathrm{O}+10$. Changes along this line can be attributed to multiple factors, including altitude, storm intensity, latitude, seasons, and continental climate (Fontes, 1980). Precipitation with greater amounts of the $\delta \mathrm{D}$ and $\delta^{18} \mathrm{O}$ (isotopically heavier) elevated above background values generally occurs at lower altitudes, at lower latitudes, during warmer weather, and closer to the coasts (Witcher and others, 2004). Values of $\delta \mathrm{D}$ and $\delta^{18} \mathrm{O}$ that deviate from the GMWL can result from one of two processes: (1) evaporation prior to recharge and (2) oxygen isotope exchange with rocks (Witcher and others, 2004). Evaporation can cause preferential loss of water molecules containing the lighter stable isotopes of hydrogen and oxygen, which can be identified by elevated $\delta \mathrm{D}$ and $\delta^{18} \mathrm{O}$ values. Water samples that indicate gains or losses of oxygen atoms from rock-water interaction tend to deviate from the GMWL in the lateral position because there is the gain or loss of only the oxygen element (Teeple, 2017).

\section{Tritium}

${ }^{3} \mathrm{H}$ is a radioactive isotope of hydrogen with a half-life of 12.32 years and usually has two sources: natural cosmogenic ${ }^{3} \mathrm{H}$ and ${ }^{3} \mathrm{H}$ produced by the atmospheric testing of nuclear weapons (Clark and Fritz, 1997; Lucas and Unterweger, 2000). The release of excess ${ }^{3} \mathrm{H}$ into the atmosphere occurred during widespread nuclear weapons testing from about 1950 to about 1970 (Motzer, 2008). Before nuclear weapons testing, the naturally occurring concentration of ${ }^{3} \mathrm{H}$ in the atmosphere ranged from about 2 to 8 tritium units (TU) (Motzer, 2008). From about 1950 to about 1970, widespread nuclear weapons testing resulted in a substantial increase (more than $1.1 \times 10^{9}$ $\mathrm{TU})$ of ${ }^{3} \mathrm{H}$ in the atmosphere of the Northern Hemisphere (Motzer, 2008). Concentrations of ${ }^{3} \mathrm{H}$ in precipitation since 2006 have decreased globally to approximately pre-bomb background levels of 2 to 10 TU (Clark and Fritz, 1997; Phillips and Castro, 2003). The elevated ${ }^{3} \mathrm{H}$ concentrations in the atmosphere beginning in about 1950 resulted in groundwater recharge containing appreciably higher ${ }^{3} \mathrm{H}$ concentrations compared to groundwater recharged before 1950. Consequently, ${ }^{3} \mathrm{H}$ is a good tracer for groundwater that was recharged after about 1950 . The use of ${ }^{3} \mathrm{H}$ to analyze groundwater is qualitative in that definitive ages of groundwater cannot be determined, but rather, differences in ${ }^{3} \mathrm{H}$ concentrations can potentially distinguish whether the groundwater was recharged before, during, or after widespread nuclear weapons testing began in the 1950s. As noted by Hinkle (1996, p. 5) "the definition of modern water is a function of the dating tool used. Although different dating tools rely on different dates in defining the boundary between modern and old water, the range of these dates is small." The determination of groundwater age by using ${ }^{3} \mathrm{H}$ is relative to ${ }^{3} \mathrm{H}$ concentrations when samples were collected. ${ }^{3} \mathrm{H}$ is commonly measured in picocuries per liter ( $\mathrm{pCi} / \mathrm{L}$ ) or in $\mathrm{TU}$, where $3.22 \mathrm{pCi} / \mathrm{L}$ is equivalent to $1 \mathrm{TU}$ or 1 part ${ }^{3} \mathrm{H}$ in $10^{18}$ parts hydrogen (Lucas and Unterweger, 2000).

\section{Carbon-14}

${ }^{14} \mathrm{C}$ is the radioactive isotope of carbon and is naturally produced in the upper atmosphere (Plummer and others, 1994). Kalin (2000) notes that the half-life used for computing the radiocarbon age of most geologic and some hydrogeologic samples is the Libby half-life (Libby, 1955), which is 5,568 years. Because ${ }^{14} \mathrm{C}$ has a long radioactive half-life, it is useful for dating groundwater that is thousands to tens of thousands of years old (Kalin, 2000; Banner, 2004; Oden and Truini, 2013). Citing the work of Kalin (2000), Nishikawa and others (2004, p. 39) explain "carbon-14 data are expressed as percent modern carbon (pmc) by comparing ${ }^{14} \mathrm{C}$ activities to the specific activity of National Bureau of Standards [now the National Institute of Standards and Technology] oxalic acid: 13.56 disintegrations per minute per gram of carbon in the year 1950 equals 100 pmc (Kalin, 2000)."

Groundwater recharged after 1950 likely results in a ${ }^{14} \mathrm{C}$ activity value of $100 \mathrm{pmc}$ or greater because atmospheric ${ }^{14} \mathrm{C}$ concentrations increased by as much as 20 percent owing to widespread nuclear weapons testing in the 1950s and 1960s (Plummer and others, 1994). ${ }^{14} \mathrm{C}$ typically moves into groundwater in carbon dioxide $\left(\mathrm{CO}_{2}\right)$ dissolved in precipitation or in organic carbon dissolved in surface water and soil pore water (Ingebritsen and Sanford, 1999; Raymond and Bauer, 2001). ${ }^{14} \mathrm{C}$ can enter surface water directly as water flows over the land towards stream channels (overland flow) or indirectly as the result of soil-pore water moving through the soil zone and discharging to a surface-water body (Linsley and others, 1982). Surface water in turn can provide a source of groundwater recharge through surface-water/groundwater interactions. Along the groundwater's flow path, ${ }^{14} \mathrm{C}$ concentrations slowly begin to decrease as ${ }^{14} \mathrm{C}$ decays to nitrogen- $14\left({ }^{14} \mathrm{~N}\right)$. Dilution of ${ }^{14} \mathrm{C}$ through geochemical processes, such as the dissolution of carbonates or $\mathrm{CO}_{2}$ from rocks and soil, can substantially alter the original ${ }^{14} \mathrm{C}$ concentration (Lemay, 2002). ${ }^{14} \mathrm{C}$ concentrations in groundwater may be altered, therefore, by the introduction of nonradioactive carbon- $12\left({ }^{12} \mathrm{C}\right)$ from exchange with carbon in rocks and soils that are millions of years old, resulting in apparent ${ }^{14} \mathrm{C}$ groundwater ages that are falsely old. Various types of geochemical modeling are used to correct for these effects to obtain better estimates of groundwater age (Plummer and others, 1994). Geochemical modeling to find corrected ages was not needed for the interpretations in this study; generalizations of the apparent age were made on the basis of the sample results. The age of groundwater is qualified as "apparent age" in this report because chemical processes affect the environmental tracers used to determine age. Musgrove and others (2010, p. 42) explain that "because 
it is not possible to identify and account for all physical and chemical processes that might affect groundwater age-tracer results, the apparent age of groundwater is most appropriately reported."

\section{Quality-Assurance and Quality-Control Procedures}

Quality-control data were collected during sampling in 2014 and 2016 to assess the variability and bias that may exist within the sample-collection procedures and laboratory analyses (U.S. Geological Survey, variously dated). To test for this variability and bias, two field-blank samples, four sequential-replicate samples, and two matrix-spiked environmental samples were collected. All field-blank and sequentialreplicate samples were analyzed for major ions, trace elements, nutrients, and organic compounds. Sequential-replicate samples also were analyzed for environmental tracers. Matrixspike samples were analyzed only for organic compounds.

\section{Field-Blank Analyses}

Field-blank samples were collected and processed at two well locations prior to the collection of environmental samples at those locations to ensure that equipment cleaning conducted in the field between the collection of samples from different wells was adequate and that the collection, processing, or transporting procedures in the field did not contaminate the environmental samples. Field-blank results indicate that the sample collection and handling procedures did not introduce appreciable amounts of bias to the environmental samples, with possible exceptions for calcium, cobalt, lead, zinc, and aluminum - constituents that were not used for conceptual model development. Cobalt concentrations of 0.054 and 0.066 microgram per liter $(\mu \mathrm{g} / \mathrm{L})$ were detected in each of the field-blank samples. A lead concentration of $0.04 \mu \mathrm{g} / \mathrm{L}$ and a zinc concentration of $3.5 \mu \mathrm{g} / \mathrm{L}$ were detected in one field-blank sample. An aluminum concentration of $0.02 \mu \mathrm{g} / \mathrm{L}$ was detected in the other field-blank sample. Calcium was detected in both field-blank samples, but concentrations in field-blank samples were considered negligible $(0.04$ and $0.03 \mathrm{mg} / \mathrm{L})$ compared to concentrations in all the environmental samples (greater than $30 \mathrm{mg} / \mathrm{L}$ ). Four organic compounds (dicrotophos, chlorpyrifos, metolachlor, and methyl parathion) were detected in one fieldblank sample; all detections were less than $0.03 \mu \mathrm{g} / \mathrm{L}$. Of the four organic compounds detected in the field-blank sample, metolachlor was the only organic compound detected in environmental samples. The cause for low-level concentrations of some constituents in the field-blank samples is unknown, and the detection of metolachlor in one field-blank sample $(0.006 \mu \mathrm{g} / \mathrm{L})$ may indicate that false detections could occur in environmental samples and need to be considered during interpretation of the results.

\section{Sequential-Replicate Analyses}

Four sequential-replicate samples were collected to measure the variability in results of analyses originating from sampling procedures and analytical methods. To evaluate the potential variability introduced during sample collection, processing, or laboratory analysis, the analytical results measured in an environmental sample were compared with those measured in the associated replicate sample by computing the relative percent difference (RPD) for each constituent. The RPD was computed by using the following equation:

$$
R P D=\frac{\left|C_{1}-C_{2}\right|}{\left(C_{1}+C_{2}\right) / 2} \times 100
$$

where

$$
\begin{aligned}
& C_{1} \text { is the concentration from the environmental } \\
& \text { sample and } \\
& C_{2} \text { is the concentration from the replicate sample. }
\end{aligned}
$$

RPDs of 10 percent or less indicate good agreement between the paired results if the concentrations were sufficiently large compared to their associated laboratory reporting levels (LRLs) (Childress and others, 1999; Oden and others, 2011). An RPD was not computed if either of the paired results was reported as estimated or less than the detection limit. Most RPDs did not exceed 10 percent for constituents analyzed in the four sequential-replicate sample pairs collected during this study, indicating generally good agreement between the environmental and replicate sample concentrations. RPDs exceeded 10 percent for seven trace elements (cobalt, copper, iron, lead, manganese, zinc, and antimony) in at least one sequential-replicate sample pair and for orthophosphate in only one sequential-replicate sample pair. Differences between the concentrations in paired samples where each sample concentration is low can result in large RPD values, which was the case for some of the trace elements listed and orthophosphate. The constituents with RPD values in excess of 10 percent (trace elements and orthophosphate) were not relevant to the conceptual model development and are not discussed further in the report. RPDs did not exceed 10 percent for any organic constituents but did exceed 10 percent for tritium for two of the sequential-replicate pairs. Differences between tritium concentrations ( 0.6 and $0.9 \mathrm{TU})$ did not affect determination of relative ages in samples.

\section{Matrix Spikes Analyses}

A spiked environmental sample is an environmentalreplicate sample to which a known volume containing known concentrations of target constituents is added in the field (Wilde and others, 2004; Martin and others, 2009). Water was collected from the well and processed following standard procedures to produce two samples (U.S. Geological Survey, variously dated; Shelton, 1994; Koterba and others, 1995). Spike solution was added to only one of the two water samples, 
resulting in spiked and unspiked samples (the matrix spike and the "background" sample, respectively). Matrix spikes are usually collected to determine any matrix interference and the analyzing laboratory's ability to recover constituent concentrations (Zaugg and others, 1995; Menheer and Brigham, 1997; Mueller and others, 1997).

Unspiked and spiked environmental samples were used to assess bias and variability from degradation of organic compound concentrations during sample processing, storage, and analysis. Analytical recoveries of the spiked target constituents are expressed as percentages of expected (theoretical) concentrations. The percent recoveries of constituents in spiked environmental samples were compared to theoretical and laboratory recoveries to evaluate matrix interferences or degradation of organic compounds. Percent recovery is computed as follows:

$$
\begin{aligned}
& \text { Percent recovery }= \\
& {\left[\left(C_{\text {spiked }}-C_{\text {unspiked }}\right) \times 100\right] / C_{\text {expected }}}
\end{aligned}
$$

where

$$
\begin{array}{cl}
C_{\text {spiked }} & \text { is the measured concentration in the spiked } \\
& \text { environmental sample in micrograms } \\
\text { per liter; } & \\
C_{\text {unspiked }} & \text { is the measured concentration in the unspiked } \\
\text { environmental sample in micrograms per } \\
\text { liter; and } \\
C_{\text {expected }} \\
\text { is the theoretical concentration in the spiked } \\
\text { environmental sample in micrograms per } \\
\text { liter and is computed as follows: }
\end{array}
$$

$$
C_{\text {expected }}=\left(C_{\text {solution }} \times V_{\text {spike }}\right) / V_{\text {sample }}
$$

where

$$
\begin{gathered}
C_{\text {solution }} \quad \begin{array}{c}
\text { is the concentration of constituent in the spike } \\
\text { solution in micrograms per liter; }
\end{array} \\
V_{\text {spike }} \quad \begin{array}{c}
\text { is the volume of spike added to the } \\
\text { environmental sample in milliliters; and }
\end{array} \\
V_{\text {sample }} \quad \begin{array}{c}
\text { is the volume of the environmental sample } \\
\text { in milliliters. }
\end{array}
\end{gathered}
$$

Constituent concentrations less than the LRL were set to zero for the purpose of computing percent recovery.

A mixture of target constituents was added to one of the environmental-replicate samples for spike analysis. Two matrix-spike analyses were done for two different wells.

Percent recoveries were computed for each of the constituents, with the optimum value being 100 percent (Mueller and others, 2015; Shoda and others, 2018). Depending on the constituent, overall percent recoveries for this study ranged from approximately 38.5 to 88.9 percent for the organic compounds detected in samples, with each organic constituent detected in this study having a different range in percent recovery. For example, prometryn, prometon, metolachlor, atrazine, and acetochlor had higher percent recoveries of 72.2-88.9 percent, but deethylatrazine, cyfluthrin, and trifluralin had lower percent recoveries of 38.5-65.5 percent. If a selected constituent has a substantially high or low recovery, environmental sample results of the organic constituent could be affected, but reported concentrations of organic compounds were not adjusted to account for results of matrix-spike analyses. Because recoveries for deethylatrazine were consistently low in laboratory recovery spiked samples (around 53 percent), all concentrations for that constituent are reported as estimated. Concentrations of selected organic compounds measured in the unspiked environmental samples that were less than the respective LRL or that were not detected were considered irrelevant, and their recoveries were not evaluated in the matrix spike results.

\section{Geochemical Characteristics}

Groundwater chemistry can vary on the basis of water interacting with the surrounding rock in an aquifer and water mixing from different sources (Hem, 1985). To better understand general water quality and provide insights into groundwater-flow paths and recharge areas, water-quality samples were collected in the study area in 2014 and 2016 from 51 wells in Gaines, Terry, and Yoakum Counties in Texas (11 wells in Gaines County, 20 wells in Terry County, and 20 wells in Yoakum County) (table 2; fig. 3). The initial sampling design outlined a plan to collect an equal number of water-quality samples from each aquifer (Ogallala, EdwardsTrinity [High Plains], and Dockum aquifers) in the three counties. The aquifer designations of several wells were changed after comparing the sampling interval of the wells to the hydrogeologic framework developed in this study. Therefore, the resulting number of wells per each aquifer became uneven with 26 wells completed in the Ogallala aquifer, 12 wells completed in the Edwards-Trinity (High Plains) aquifer, 5 wells completed in the Dockum aquifer, and 8 wells completed in any combination of two or more of the aquifers in the study area (hereinafter referred as a "combination" of aquifers) (table 2; fig. 3). The uneven distribution of wells in the various aquifers in the study area was partly due to a lack of wells available for sampling and the predominance of wells in the Ogallala aquifer.

Physicochemical properties and other constituents were used to evaluate general water quality, aquifer interactions, and potential source areas of groundwater by examining and comparing hydrochemical facies, DS, nutrients, trace elements, organic compounds, and environmental tracers such as ${ }^{87} \mathrm{Sr} / 86 \mathrm{Sr}, \delta \mathrm{D}, \delta{ }^{18} \mathrm{O},{ }^{3} \mathrm{H}$, and ${ }^{14} \mathrm{C}$ concentrations. All water-quality results were used in combination to identify the chemical characteristics of water in these counties and provide insight into potential groundwater-flow paths. The qualitative geochemical analysis does not include a quantitative evaluation of residence times in the aquifer nor does it include geochemical flow-path modeling of the groundwater system. 
Table 3. U.S. Environmental Protection Agency primary and secondary drinking water standards, U.S. Geological Survey health-based screening levels, and the percent of samples that exceeded the designated standard or level for selected constituents analyzed in groundwater samples in Gaines, Terry, and Yoakum Counties, Texas, 2014 and 2016.

[MCL, maximum contaminant level; HBSL, health-based screening level; mg/L, milligram per liter; $\mu \mathrm{g} / \mathrm{L}$, microgram per liter; --, no value. MCLs from U.S. Environmental Protection Agency, 2020; HBSLs from U.S. Geological Survey, 2020c]

\begin{tabular}{lcccc}
\hline \multicolumn{1}{c}{ Constituent } & $\begin{array}{c}\text { Primary } \\
\text { MCL standard }\end{array}$ & $\begin{array}{c}\text { Secondary } \\
\text { MCL standard }\end{array}$ & HBSL & $\begin{array}{c}\text { Samples exceeding } \\
\text { MCL or HBSL } \\
\text { (percent) }\end{array}$ \\
\hline Dissolved solids $(\mathrm{mg} / \mathrm{L})$ & -- & 500 & -- & 92 \\
Nitrate $(\mathrm{mg} / \mathrm{L})$ & 10 & -- & -- & 35 \\
Chloride $(\mathrm{mg} / \mathrm{L})$ & -- & 250 & -- & 27 \\
Fluoride $(\mathrm{mg} / \mathrm{L})$ & 4.0 & -- & -- & 49 \\
Sulfate $(\mathrm{mg} / \mathrm{L})$ & -- & 250 & -- & 59 \\
Arsenic $(\mu \mathrm{g} / \mathrm{L})$ & 10 & -- & -- & 76 \\
Strontium $(\mu \mathrm{g} / \mathrm{L})$ & -- & -- & 4,000 & 29 \\
Selenium $(\mu \mathrm{g} / \mathrm{L})$ & 50 & -- & -- & 6 \\
\hline
\end{tabular}

As a baseline indicator of the significance of the amount of constituent measured within the groundwater, oftentimes constituent concentrations are compared with U.S. Environmental Protection Agency (EPA) designated drinking water standards and USGS health-based screening levels (table 3) (U.S. Environmental Protection Agency, 2020; U.S. Geological Survey, 2020c). Arsenic is one of the constituents for which sample concentrations exceeded the primary maximum contaminant level of $10 \mu \mathrm{g} / \mathrm{L}$ in 76 percent of the samples collected in the study (table 3). Arsenic was not included in the conceptual model development but is a trace element often detected at concentrations exceeding $10 \mu \mathrm{g} / \mathrm{L}$ in the Ogallala aquifer. Arsenic is thought to be associated with historical arsenic acid use in agricultural settings but also can come from natural sources such as marine shale, saline lakes, volcanic-ash deposits, and iron-oxide minerals in the aquifer (Fahlquist, 2003; Scanlon and others, 2005; and Gurdak and others, 2009).

\section{Hydrochemical Facies}

The composition of groundwater principally is controlled by the composition of recharge water, water-rock interaction, and the mixing of water from different sources. The term "facies" refers to a classification scheme used to describe water in terms of the major cation and anion milliequivalents composition (Freeze and Cherry, 1979; Bartos and Ogle, 2002). A trilinear (Piper) diagram is a useful tool for evaluating the relative abundance of major cations and anions and classifying facies or water types (Piper, 1944). Hydrochemical facies are complex and varied within the aquifers in the study area, indicating possible groundwater interactions among the aquifers in the study area. Specific hydrochemical facies do not seem to be associated with any particular aquifer in the

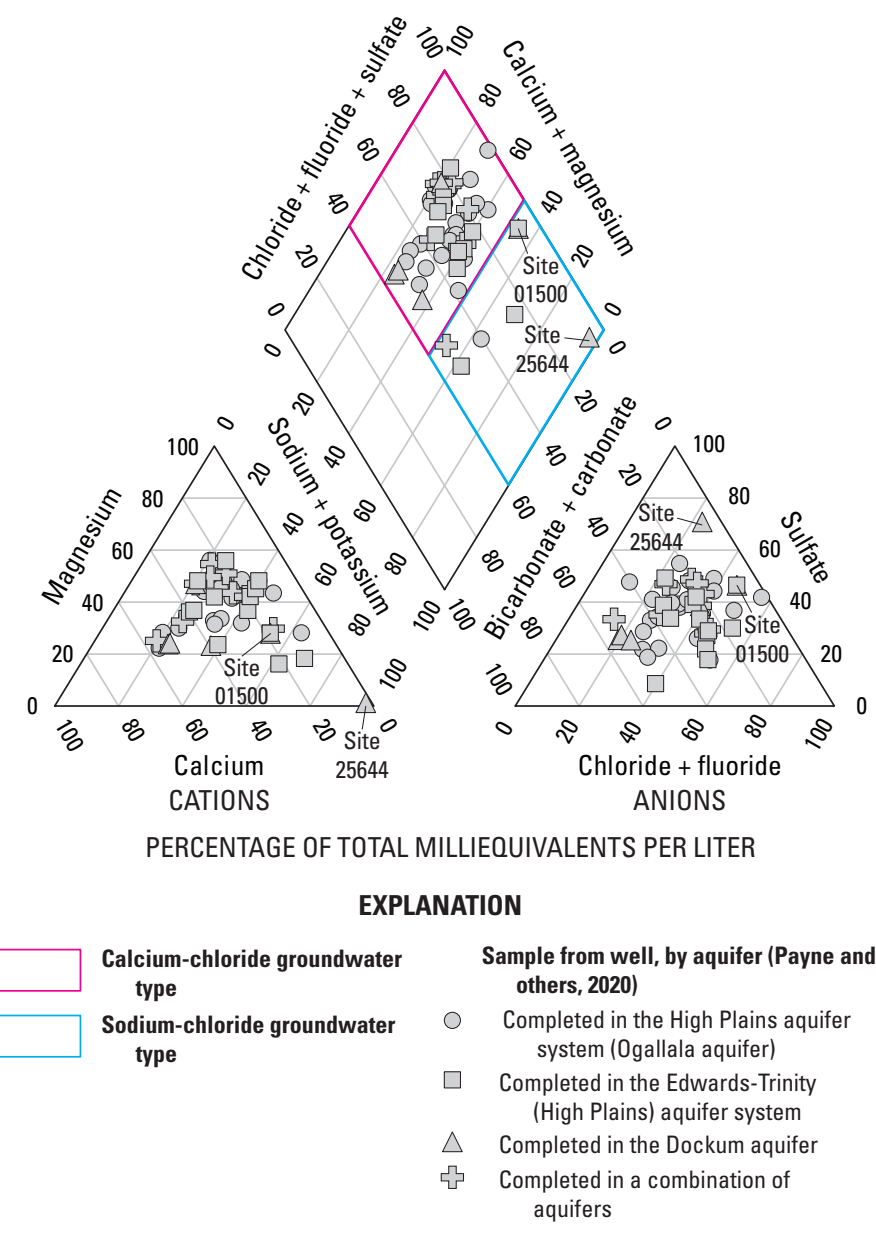

Figure 9. Relations between major cations and anions measured in water-quality samples from groundwater wells in Gaines, Terry, and Yoakum Counties, Texas, 2014 and 2016. 
study area (fig. 9). Most of the samples were classified as calcium-chloride groundwater type. Seven samples were classified as sodium-chloride groundwater type.

\section{Dissolved Solids}

DS concentrations are a measure of how many dissolved constituents are in a sample. Sodium and chloride are often the primary constituents that contribute to elevated DS concentrations (Hem, 1985). In this report, DS concentrations of less than or equal to $1,000 \mathrm{mg} / \mathrm{L}$ are considered indicative of freshwater, whereas DS concentrations greater than $1,000 \mathrm{mg} / \mathrm{L}$ and less than $10,000 \mathrm{mg} / \mathrm{L}$ are considered indicative of brackish water (Winslow and Kister, 1956). DS concentrations in the groundwater samples collected in the study area range from 424 to 5,900 mg/L (Payne and others, 2020; fig. 10) with the median DS concentration of $1,020 \mathrm{mg} / \mathrm{L}$ (Payne and others, 2020). DS concentrations of less than $1,000 \mathrm{mg} / \mathrm{L}$ were measured in less than one-half (47 percent) the wells sampled in the study area. The EPA secondary drinking-water standard for DS concentrations is $500 \mathrm{mg} / \mathrm{L}$ for color, taste, and odor issues (table 3) (U.S. Environmental Protection Agency, 2020). The DS concentration exceeded $500 \mathrm{mg} / \mathrm{L}$ in 92 percent of the wells sampled. The highest DS concentrations $(5,900$ and $4,900 \mathrm{mg} / \mathrm{L})$ were measured in two wells (sites 25644 and 01500, respectively) in Gaines County (fig. 10); the highest sodium (2,040 and $942 \mathrm{mg} / \mathrm{L})$ and chloride (646 and $1,030 \mathrm{mg} / \mathrm{L}$ ) concentrations were also measured in these same two wells (fig. 9) (Payne and others, 2020). Of the wells sampled in Terry County, 100 percent had DS concentrations greater than $500 \mathrm{mg} / \mathrm{L}$, whereas 95 percent of the wells sampled in Gaines County and 85 percent of the wells sampled in Yoakum County had DS concentrations exceeding $500 \mathrm{mg} / \mathrm{L}$.

\section{Nutrients}

Elevated nutrient concentrations in groundwater (predominantly in the forms of nitrate and nitrite) can result from surface-water infiltration in agricultural or municipal areas. Nutrient sources typically include livestock manure, septic systems, municipal treatment systems, or fertilizers (Dubrovsky and others, 2010). National background concentrations of nitrate, the most common form of nitrogen in groundwater, were estimated to be $1 \mathrm{mg} / \mathrm{L}$ (Dubrovsky and others, 2010). Nitrate plus nitrite concentrations in the groundwater samples collected in the study area ranged from less than the detection limit of $0.04 \mathrm{mg} / \mathrm{L}$ to $98.2 \mathrm{mg} / \mathrm{L}$ (Payne and others, 2020; fig. 11) with the median concentration at $7 \mathrm{mg} / \mathrm{L}$ (Payne and others, 2020). The concentration of nitrate plus nitrite exceeded the EPA primary maximum contaminant level of $10 \mathrm{mg} / \mathrm{L}$ in 35 percent of the samples from the study area (table 3). Nitrite concentrations in the study area were negligible with detectable concentrations $(0.001-0.057 \mathrm{mg} / \mathrm{L})$ in less than 30 percent of samples, indicating that most of the nitrogen in the groundwater is nitrate (Payne and others,
2020). The greatest percentage (60 percent) of wells sampled with nitrate plus nitrite concentrations greater than the drinking water standard for nitrate were in Terry County, whereas 27 percent were in Gaines County, and 15 percent were in Yoakum County (fig. 11). The pattern observed for nitrate plus nitrate concentrations (highest in Terry County, followed by Gaines and Yoakum Counties), is similar to the pattern observed for DS concentrations. There appears to be a relation between DS and nitrate plus nitrite concentrations (fig. 12), which may indicate that the elevated DS concentrations in the study area could be related to surface-water infiltration to the aquifers, similar to nutrient sources.

\section{Organic Compounds}

Organic compounds such as herbicides and insecticides detected in groundwater samples likely result from surfacewater infiltration and anthropogenic (human) influences on groundwater in the study area. Groundwater samples were analyzed for 83 organic compounds, and the only organic compounds detected in this study were acetochlor, atrazine, metolachlor, prometon, prometryn, trifluralin, cyfluthrin, and deethylatrazine (Payne and others, 2020). All organic compounds detected are herbicides, except for cyfluthrin, an insecticide, and deethylatrazine, an atrazine degradate. Herbicides are commonly used in these counties because of the extensive agricultural land use in the region (fig. 3). All concentrations for these organic compounds were very low (less than $0.03 \mu \mathrm{g} / \mathrm{L}$ ). Often groundwater samples collected from a given well will have detections of multiple organic compounds. In this study, three organic compounds were detected in the sample collected from one well (site 10061) (fig. 3, table 2), which was the greatest number of organic compounds detected in the samples collected from any well sampled for this study (Payne and others, 2020). Two organic compounds were detected in each of the samples collected from 10 wells (sites 01500 , 04518, 04809, 10509, 10523, 12504, 18790, 20215, 20759, and 25865). At least one organic compound was detected in the samples collected from 26 of the 51 wells; metolachlor (detected in the samples from 16 wells) (fig. 13A) and deethylatrazine (detected in the samples from 12 wells) (fig. 14A) were the most commonly detected compounds (Payne and others, 2020).

Twenty groundwater wells in Gaines, Terry, and Yoakum Counties were sampled for organic compounds during 2001-03 as part of previous studies done by the USGS (Fahlquist, 2003; Stanton and Fahlquist, 2006). The same detection limits for the analysis of metolachlor and deethylatrazine (the two most commonly detected organic compounds in this study) were used in this study as were used to analyze the samples collected during 2001-03 (Fahlquist, 2003; Stanton and Fahlquist, 2006). Metolachlor was not detected in groundwater samples collected from any of the wells sampled in these previous studies (fig. 13B), and deethylatrazine was detected in the samples from only three wells (fig. 14B). Even though the number of detections increased in samples collected in this study compared to the number of detections in 


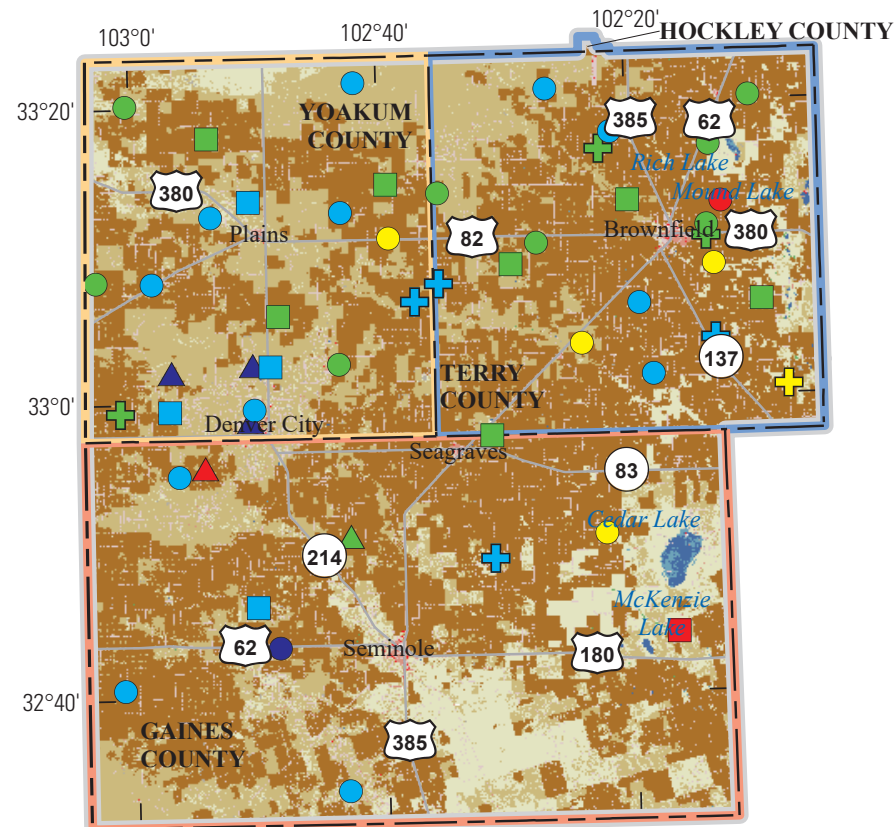

Base from U.S. Geological Survey National Land Cover Database Universal Transverse Mercator projection, zone 13

North American Datum of 1983

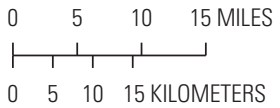

EXPLANATION

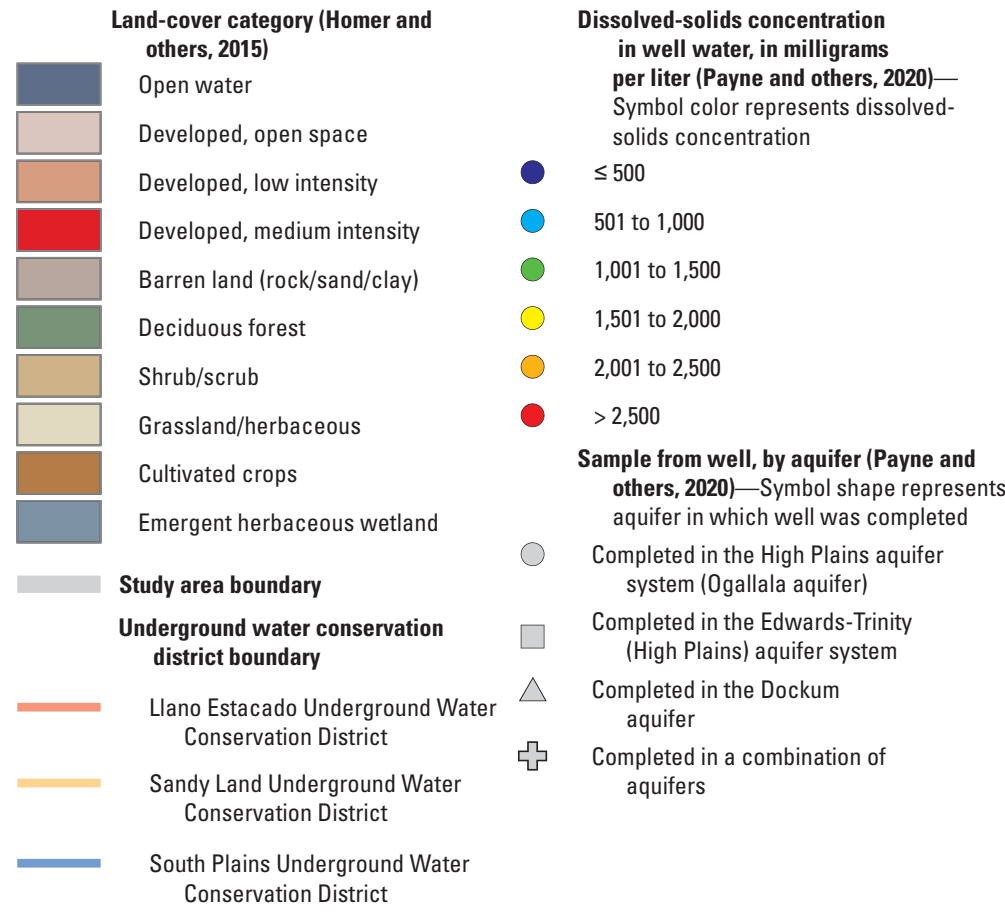

Figure 10. Dissolved-solids concentrations in groundwater wells sampled in Gaines, Terry, and Yoakum Counties, Texas, 2014 and 2016. 


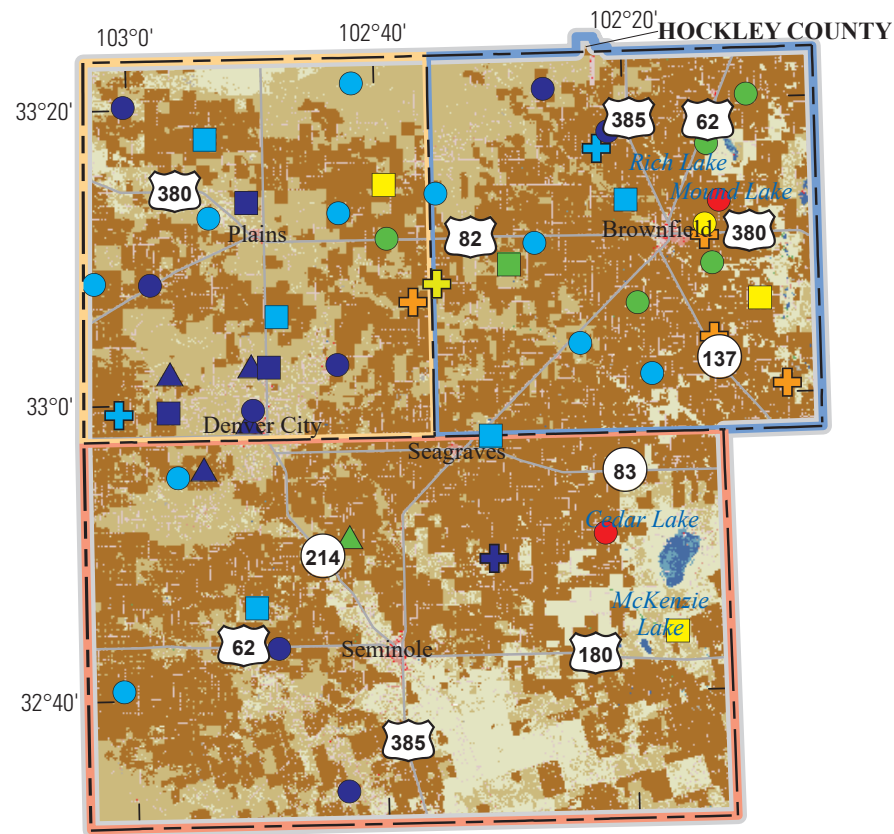

Base from U.S. Geological Survey National Land Cover Database $\begin{array}{llll}0 & 5 & 10 & 15 \text { MILES }\end{array}$ Universal Transverse Mercator projection, zone 13 North American Datum of 1983

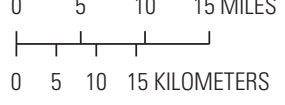

\section{EXPLANATION}

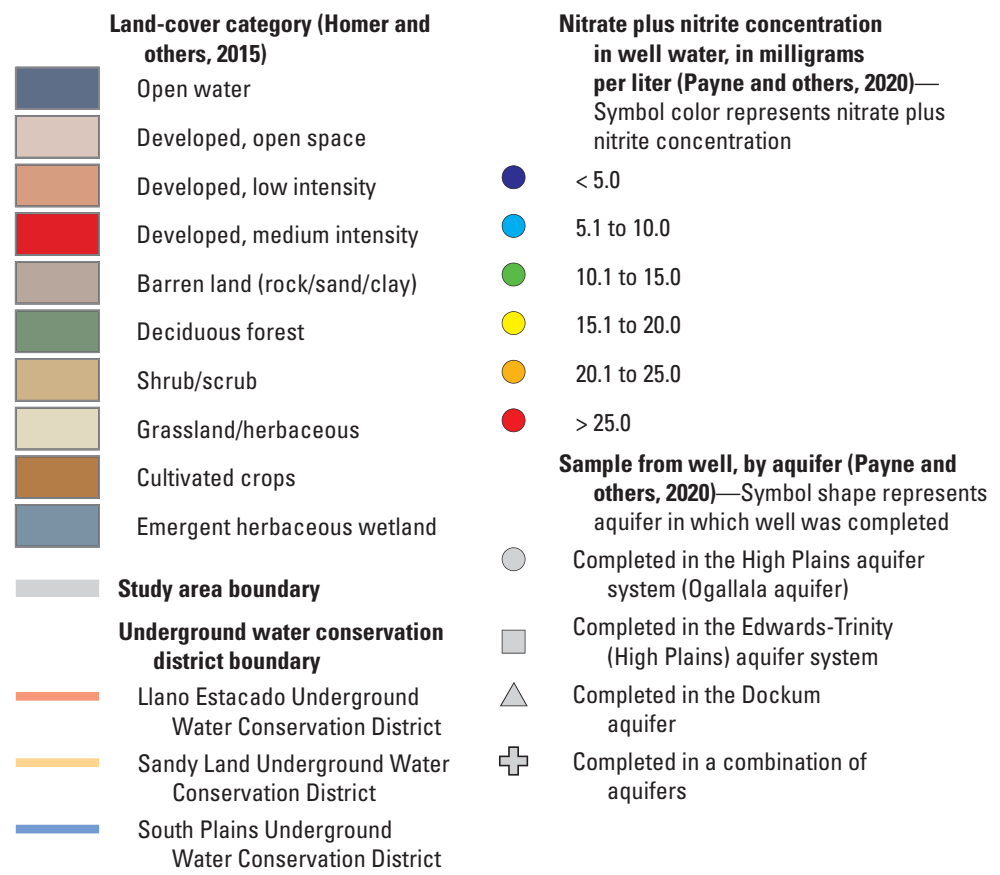

Figure 11. Nitrate plus nitrite concentrations in water-quality samples from groundwater wells in Gaines, Terry, and Yoakum Counties, Texas, 2014 and 2016. 


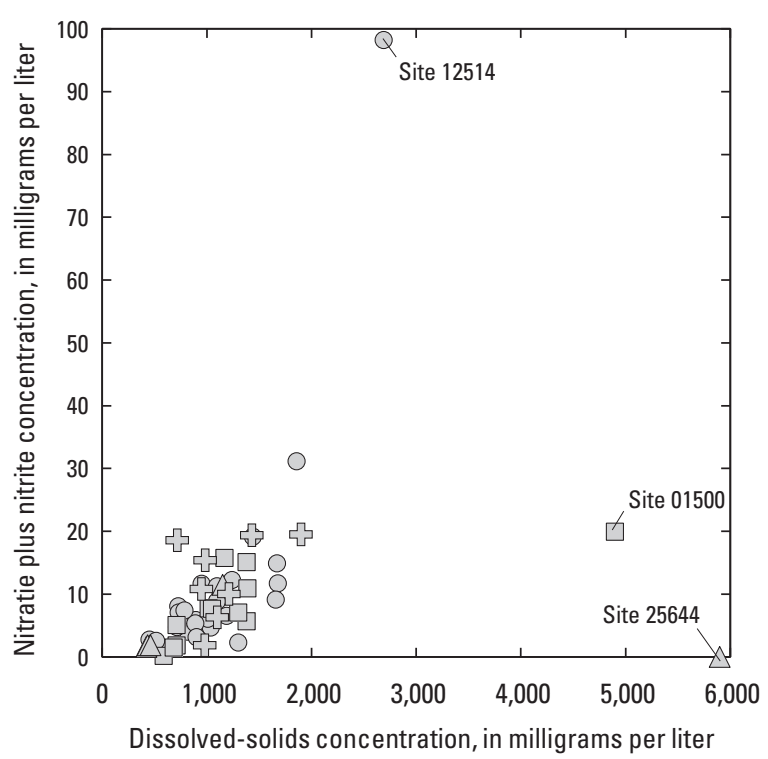

EXPLANATION

\section{Sample from well, by aquifer (Payne and others, 2020)}

- Completed in the High Plains aquifer system (Ogallala aquifer)

$\square \quad$ Completed in the Edwards-Trinity (High Plains) aquifer system

$\triangle \quad$ Completed in the Dockum aquifer

ङ Completed in a combination of aquifers

Figure 12. Relation between dissolved-solids and nitrate plus nitrite concentrations in water-quality samples from groundwater wells in Gaines, Terry, and Yoakum Counties, Texas, 2014 and 2016.

samples collected in previous studies, detected concentrations remain very low (less than $0.03 \mu \mathrm{g} / \mathrm{L}$ ). Similar to the pattern observed for DS and nutrient detections, the greatest number of detections for metolachlor and deethylatrazine were in samples collected in Terry County (fig. 13; fig. 14).

\section{Environmental Tracers}

Environmental tracers, such as ${ }^{87} \mathrm{Sr} / 86 \mathrm{Sr}, \delta \mathrm{D}$ and $\delta^{18} \mathrm{O}$, ${ }^{3} \mathrm{H}$, and ${ }^{14} \mathrm{C}$ in groundwater, are useful for understanding where and when groundwater recharge occurred in an aquifer system. The ${ }^{87} \mathrm{Sr} / 86 \mathrm{Sr}$ ratio can provide a useful tool for determining the source of dissolved constituents to water because the ${ }^{87} \mathrm{Sr} /{ }^{86} \mathrm{Sr}$ ratio undergoes negligible fractionation during rock-water interactions (Banner, 2004; Bumgarner and others, 2012). Therefore, water in specific geologic units are expected to have ${ }^{87} \mathrm{Sr} / 86 \mathrm{Sr}$ values that reflect the isotopic ratio of minerals in that specific aquifer unit (Kendall and McDonnell, 1998). Median ${ }^{87} \mathrm{Sr} / 86 \mathrm{Sr}$ values were computed for each aquifer for the groundwater samples collected in this study. The ranges and median values for ${ }^{87} \mathrm{Sr} /{ }^{86} \mathrm{Sr}$ were slightly different for the samples representing the Ogallala, Edwards-Trinity (High Plains), and Dockum aquifers (fig. 15) (Payne and others, 2020). The median ${ }^{87} \mathrm{Sr} /{ }^{86} \mathrm{Sr}$ values for samples collected from wells completed in the Ogallala, Edwards-Trinity (High
Plains), and Dockum aquifers were $0.70861,0.70857$, and 0.70866 , respectively, whereas the median ${ }^{87} \mathrm{Sr} / 86 \mathrm{Sr}$ value for samples collected from wells completed in a combination of those aquifers was 0.70862 . As may be expected, the median ${ }^{87} \mathrm{Sr} / 86 \mathrm{Sr}$ value for samples collected from wells completed in a combination of aquifers was between the median ${ }^{87} \mathrm{Sr} / 86 \mathrm{Sr}$ values for samples collected from wells completed in the Ogallala and Dockum aquifers and between median ${ }^{87} \mathrm{Sr} / 86 \mathrm{Sr}$ values from samples collected from wells completed in the Edwards-Trinity (High Plains) and Dockum aquifers, thereby supporting the mixed nature of the water in wells completed in a combination of aquifers. ${ }^{87} \mathrm{Sr} / 86 \mathrm{Sr}$ values for groundwater sampled from wells completed in the Edwards-Trinity (High Plains) aquifer in this study $(0.70842-0.70866)$ were within the range of ${ }^{87} \mathrm{Sr} / 86 \mathrm{Sr}$ values reported in Bumgarner and others (2012) (0.70788 to 0.70979) for the same aquifer. According to Burke and others (1982), values for Permianand Cretaceous-age carbonate and evaporite rocks are expected to range from 0.7068 to 0.7084 , but Bumgarner and others (2012) state that the "additional sources of strontium (siliciclastics) with the interpreted complex stratigraphy and structural geology of the Pecos County region" may be contributing to the higher ${ }^{87} \mathrm{Sr} / 86 \mathrm{Sr}$ values. The range of ${ }^{87} \mathrm{Sr} /{ }^{86} \mathrm{Sr}$ values measured in samples from wells completed in the Dockum aquifer in this study (0.70847-0.70869) is within the range of ${ }^{87} \mathrm{Sr} / 86 \mathrm{Sr}$ values reported for the Dockum aquifer in Bumgarner and others (2012) (0.70743-0.70975). As with the Edwards-Trinity (High Plains) aquifer, the siliciclastic rocks of the Dockum aquifer may be contributing to the higher ${ }^{87} \mathrm{Sr} / 86 \mathrm{Sr}$ values observed by Bumgarner and others (2012). ${ }^{87} \mathrm{Sr} / 86 \mathrm{Sr}$ values representing water in the Ogallala aquifer in this study could not be compared to ${ }^{87} \mathrm{Sr} /{ }^{86} \mathrm{Sr}$ values reported by Bumgarner and others (2012) because the Ogallala aquifer is not present in the Pecos County region. Overall ${ }^{87} \mathrm{Sr} / 86 \mathrm{Sr}$ values in this study are similar to ${ }^{87} \mathrm{Sr} / 86 \mathrm{Sr}$ values reported in previous studies done near this study area.

Groundwater samples from the study area were analyzed for oxygen and hydrogen stable isotopes of water to help with the determination of recharge and flow paths. Oxygen and hydrogen stable isotopes of water are useful indicators of conditions present at the time and place of groundwater recharge (Faure, 1986; Uliana and others, 2007). The ratios of $\delta \mathrm{D}$ to $\delta^{18 \mathrm{O}}$ in groundwater samples can be used to evaluate the evaporation process along a flow path because evaporation causes the preferential loss of water molecules containing the lighter stable isotopes of hydrogen (hydrogen-1) and oxygen (oxygen-16) and therefore deviation from the GMWL (Witcher and others, 2004). Comparison of the ratios of $\delta \mathrm{D}$ to $\delta^{18} \mathrm{O}$ values in groundwater samples collected in the study area to the GMWL can help determine changes to water chemistry from precipitation infiltrating into the groundwater system. All but one of the $\delta \mathrm{D}$ to $\delta^{18} \mathrm{O}$ ratios for groundwater samples collected in this study plot are below the GMWL (fig. 16) because evaporation and rock-water interactions along flow paths can cause different $\delta \mathrm{D}$ and $\delta^{18} \mathrm{O}$ values in groundwater samples compared to $\delta \mathrm{D}$ and $\delta^{18} \mathrm{O}$ values in precipitation. 


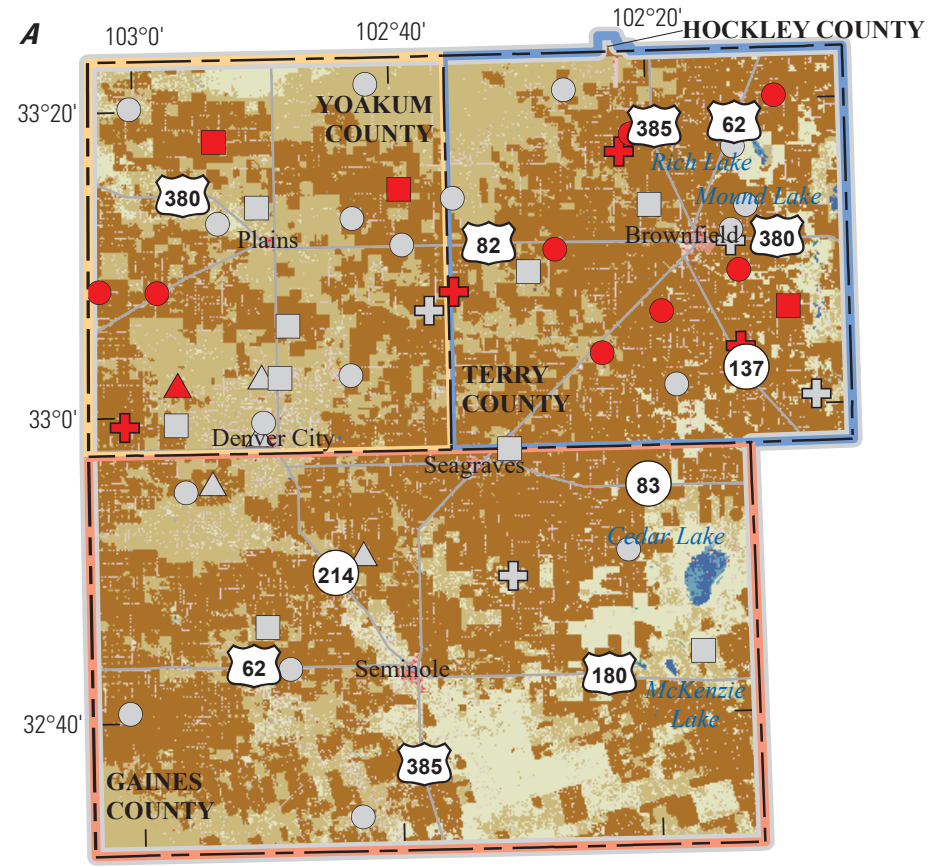

Base from U.S. Geological Survey National Land Cover Database Universal Transverse Mercator projection, zone 13

North American Datum of 1983

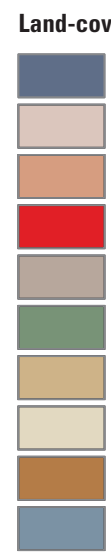

Developed, open space

Developed, medium intensity

Barren land (rock/sand/clay)

Deciduous forest

Shrub/scrub

Cultivated crops

Emergent herbaceous wetland

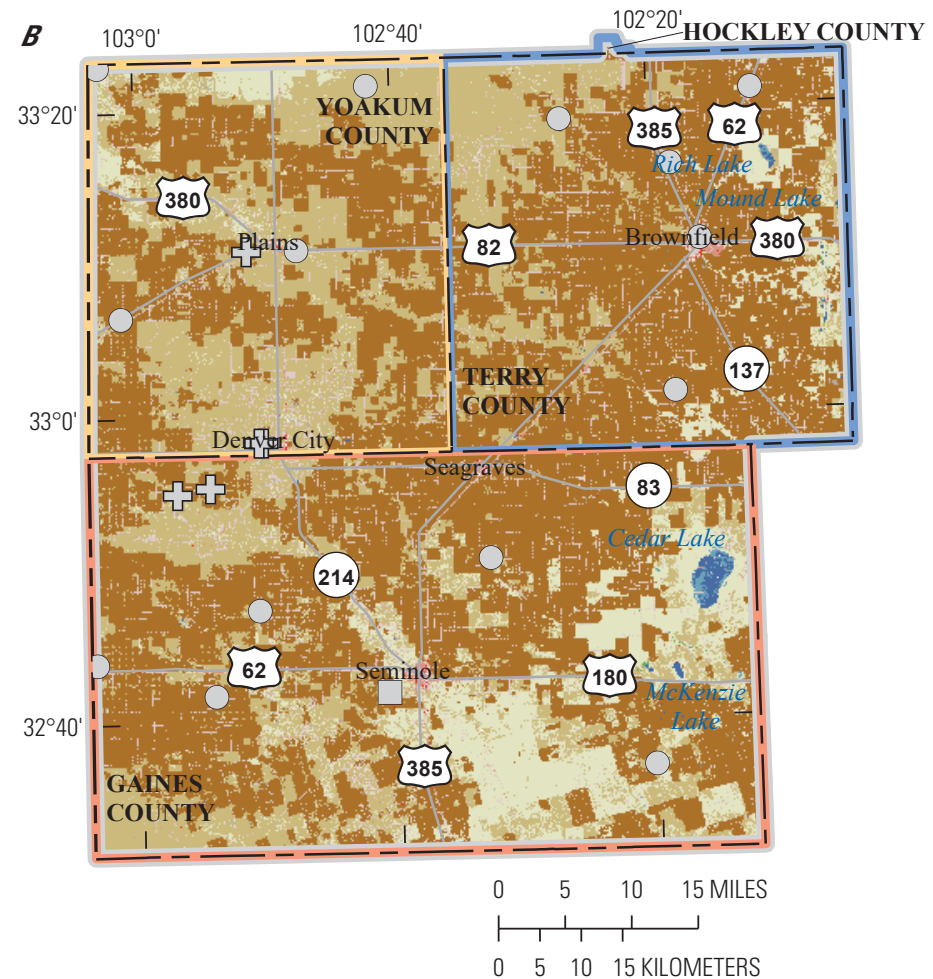

EXPLANATION

Developed, low intensity

Grassland/herbaceous
Study area boundary

Underground water conservation district boundary

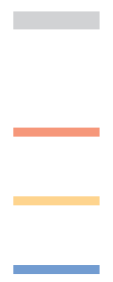

Llano Estacado Underground Water Conservation District

Sandy Land Underground Water Conservation District

South Plains Underground Water Conservation District

Metolachlor concentration detection in well water (Payne and represents detect or non-detect

Detection of metolachlor in sample

No detection of metolachlor in others, 2020)-Symbol color $\begin{array}{llll}0 & 5 & 10 & 15 \text { KILOMETERS }\end{array}$

Sample from well, by aquifer (Payne and others, 2020)—Symbol shape represents aquifer in which well was completed

Completed in the High Plains aquifer system (Ogallala aquifer)

Completed in the Edwards-Trinity (High Plains) aquifer system

$\triangle$ Completed in the Dockum aquifer

乌 Completed in a combination of aquifers

Figure 13. Metolachlor concentrations detected in water-quality samples from groundwater wells in Gaines, Terry, and Yoakum Counties, Texas, A, 2014 and 2016 and B, 2000-03 (Fahlquist, 2003; Stanton and Fahlquist, 2006). 


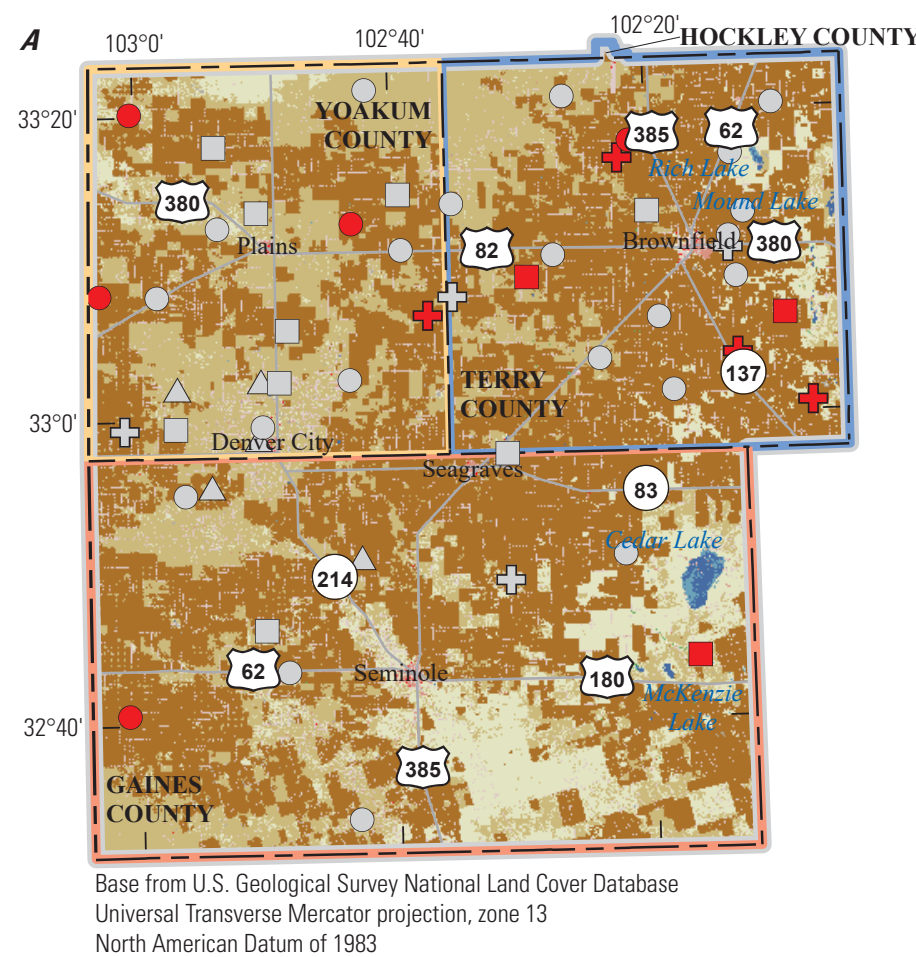

North American Datum of 1983

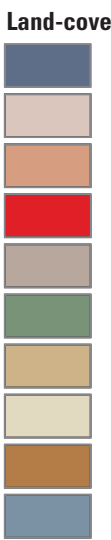

Grassland/herbaceous

\section{EXPLANATION}

\section{Study area boundary}

Underground water conservation district boundary

Developed, open space

Developed, low intensity

Developed, medium intensity

Barren land (rock/sand/clay)

Deciduous forest

Shrub/scrub

Cultivated crops

Emergent herbaceous wetland

Llano Estacado Underground Water Conservation District

Sandy Land Underground Water Conservation District

South Plains Underground Water Conservation District

Deethylatrazine concentration detection in well water (Payne and others, 2020)—Symbol color represents detect or non-detect

Detection of deethylatrazine in sample

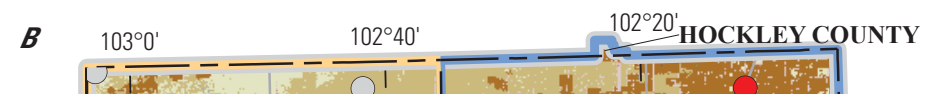

O $510 \quad 15$ KILOMETERS

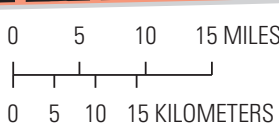

No detection of deethylatrazine in sample

Sample from well, by aquifer (Payne and others, 2020)—Symbol shape represents aquifer in which well was completed

Completed in the High Plains aquifer system (Ogallala aquifer)

Completed in the Edwards-Trinity (High Plains) aquifer system

$\triangle \quad$ Completed in the Dockum aquifer

§ Completed in a combination of aquifers

Figure 14. Deethylatrazine concentrations detected in water-quality samples from groundwater wells in Gaines, Terry, and Yoakum Counties, Texas, A, 2014 and 2016 and B, 2000-03 (Fahlquist, 2003; Stanton and Fahlquist, 2006). 


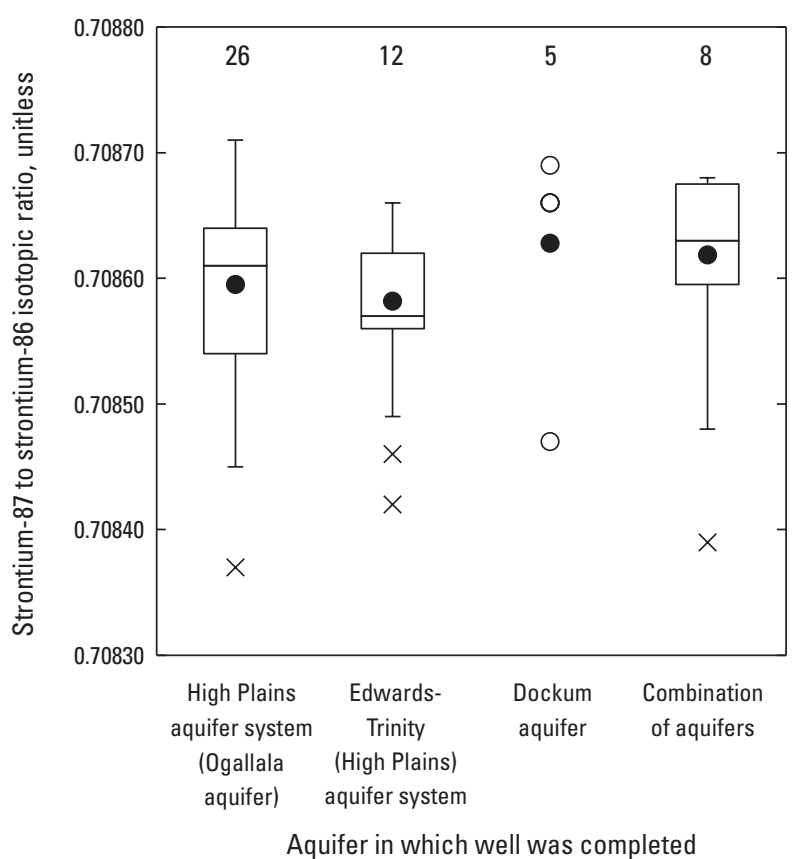

EXPLANATION

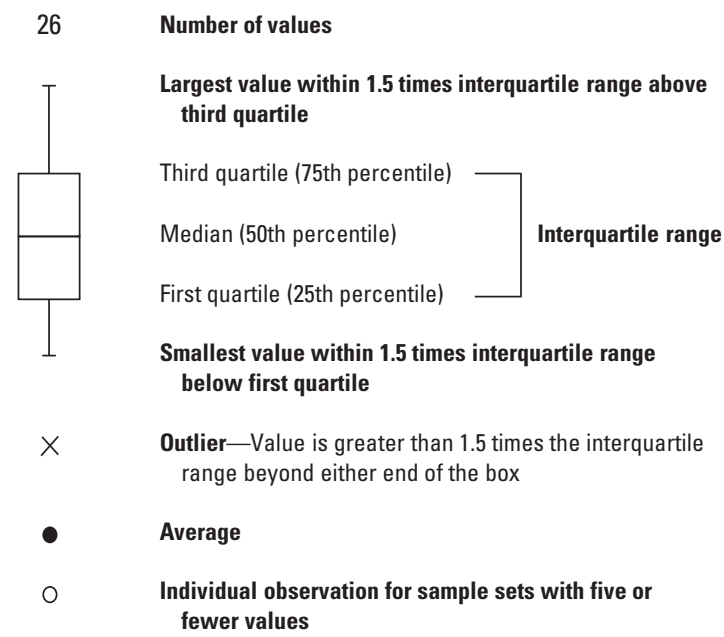

Figure 15. Strontium isotopic values in water-quality samples from groundwater wells in Gaines, Terry, and Yoakum Counties, Texas, 2014 and 2016.

$\delta \mathrm{D}$ to $\delta^{18} \mathrm{O}$ values in groundwater samples collected in this study do not have ratios specific to an aquifer (fig. 16), but a slight connection may exist between the $\delta \mathrm{D}$ to $\delta^{18} \mathrm{O}$ ratios and geographic location, supporting a general groundwater-flow direction from west (Yoakum County) to east (Terry County). Heavier (higher) isotopic values of $\delta \mathrm{D}$ and $\delta^{18} \mathrm{O}$, which can occur downgradient from flow paths, tended to be measured in the samples collected in Terry County (fig. 16). The lighter isotopic values measured in samples collected in a western part of the study area (Yoakum County) can be indicative of historically older waters within colder climate conditions (Gat and Gonfiantini, 1981; Jouzel and others, 1994).

Samples from groundwater wells in the study area were analyzed for ${ }^{3} \mathrm{H}$ and ${ }^{14} \mathrm{C}$ to gain insights regarding the age of the groundwater (Payne and others, 2020). By combining the results from ${ }^{3} \mathrm{H}$ and ${ }^{14} \mathrm{C}$ analyses and temporal variability of ${ }^{3} \mathrm{H}$ deposition in precipitation, an apparent age can be assigned to the water from a given well (Michel and others, 2018; Lindsey and others, 2019). Water that generally has ${ }^{3} \mathrm{H}$ concentrations greater than $1.5 \mathrm{TU}$ and ${ }^{14} \mathrm{C}$ concentrations greater than $60 \mathrm{pmc}$ is considered modern and is less than about 70 years old (fig. 17). The groundwater sample collected from one well (site 20215) is an outlier for the general criteria for modern water; the ${ }^{14} \mathrm{C}$ concentration measured in this sample is less than $60 \mathrm{pmc}$, possibly as a result of matrix interference during sample analysis (Plummer and others, 1994). Water that has ${ }^{3} \mathrm{H}$ concentrations less than $0.15 \mathrm{TU}$ is considered premodern and is more than several hundred years old. Water with ${ }^{3} \mathrm{H}$ concentrations generally lower than $1.5 \mathrm{TU}$ and ${ }^{14} \mathrm{C}$ concentrations less than $80 \mathrm{pmc}$ is considered a mixture of water less than about 70 years old and water more than several hundred years old (Michel and others, 2018; Lindsey and others, 2019). The evaluation of ${ }^{3} \mathrm{H}$ and ${ }^{14} \mathrm{C}$ concentrations measured in groundwater samples collected during this study indicates that a relation between the apparent ages of the groundwater and any specific aquifer does not appear to exist (fig. 17). The ${ }^{3} \mathrm{H}$ and ${ }^{14} \mathrm{C}$ concentrations have a slight connection with the spatial distribution of the groundwater samples, with the modern water frequently found in Terry County. Groundwater in the western part of the study area (western part of Gaines County and Yoakum County) seems to be older than water in the eastern part of the study area (eastern part of Gaines County and Terry County) (fig. 18). Given that groundwater in the eastern part of the study area is generally considered modern, or younger than 70 years old, groundwater would have been recently recharged, and land-use activities in the area could have had a great effect on groundwater quality. This recent recharge may explain the higher concentrations of nitrate and more frequent detections of metolachlor and deethylatrazine in Terry County. 


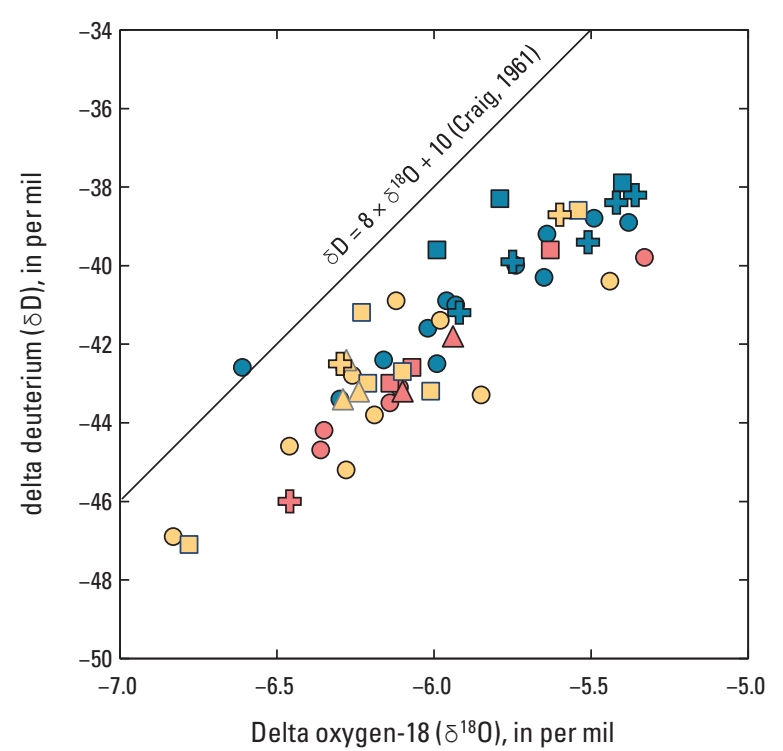

EXPLANATION

Global meteoric water line (Craig,
1961)
Sample from well, by county (Payne
and others, 2020)_Symbol color
represents county
O Gaines County
○ Terry County
$\circ \quad$ Yoakum County

Figure 16. Relation between stable isotopes of hydrogen and oxygen in water-quality samples from groundwater wells in Gaines, Terry, and Yoakum Counties, Texas, 2014 and 2016.

\section{Groundwater-Flow System}

As explained in the "Purpose and Scope" section of this report, synoptic groundwater-level measurements were made within each of the aquifers to aid in the understanding of the groundwater-flow system. By carefully reviewing the well data to ensure each measurement was characterizing the correct aquifer, the groundwater measurement data were used to develop potentiometric-surface maps for each aquifer. Potentiometric-surface maps can be used to evaluate groundwater-level-altitude changes spatially and temporally, identify regional groundwater-flow paths and gradients, and compute vertical gradients between adjacent aquifer units (Freeze and Cherry, 1979; Fetter, 1988; Thomas and others, 2016).

\section{Water-Level Measurements}

Groundwater-level data were obtained during the dormant season, defined as November 2017 through April 2018 in this report, to represent the 2018 groundwater-level altitudes of the Ogallala, Edwards-Trinity (High Plains), and
Dockum aquifers. The dormant season is when groundwater withdrawals are typically lower compared to the rest of year because virtually all the groundwater is withdrawn for irrigation purposes during the growing season in the study area. Groundwater-level-altitude data collected during the dormant season were likely unaffected by drawdown and cones of depression from agricultural pumping (Heath, 1983). The water-level measurements within the Edwards-Trinity (High Plains) and Dockum aquifers were made by USGS personnel by using a calibrated steel tape or electric water-level tape in accordance with methods described in Cunningham and Schalk (2011). All groundwater-level measurements collected by the USGS were reviewed by USGS personnel and loaded into the NWIS (U.S. Geological Survey, 2020b). The groundwater levels measured for this report were complemented with additional compiled groundwater-level data collected from the Edwards-Trinity (High Plains) and Dockum aquifers during the same dormant season (Payne and others, 2020).

To ensure that recorded groundwater-level measurements were accurate, at least two groundwater-level measurements were made at each well while the well was not being pumped. If the two measurements did not agree within $0.02 \mathrm{ft}$, then one or more additional measurements were made. The measurement in which field personnel had the most confidence was used as the final value in the case where more than two measurements were made. After the groundwaterlevel-measurement data were collected, they were thoroughly evaluated and subsequently used for the construction of potentiometric-surface maps of groundwater-level altitudes. The groundwater-level measurements made or provided for this study are given in a companion data release (Payne and others, 2020).

\section{Data Processing and Interpretation}

Using geologic and well-construction data, the aquifer assignment (aquifer or aquifers in which a given well was completed) was determined on the basis of the following criteria, in order of priority: (1) the screened or open interval(s) of the well, (2) the total depth of the well, or (3) the aquifer of completion reported for a given well by the data source. Wells that were completed in a combination of aquifers were not used for the development of the potentiometric-surface maps. Thomas and others (2016) provide a detailed discussion on how the aquifer assignments were determined from these criteria.

Potentiometric-surface maps of groundwater-level altitudes were created to help assess spatial changes in groundwater across the study area and within each aquifer. The groundwater-level measurements were converted from depths below land surface to altitudes by subtracting the depths from the 3DEP (U.S. Geological Survey, 2017). Potentiometric-surface maps for the Edwards-Trinity (High Plains) and Dockum aquifers were created by using Oasis montaj (Seequent, 2020a), as described in Thomas and others (2016). Gridded surfaces of the groundwater-level altitudes 


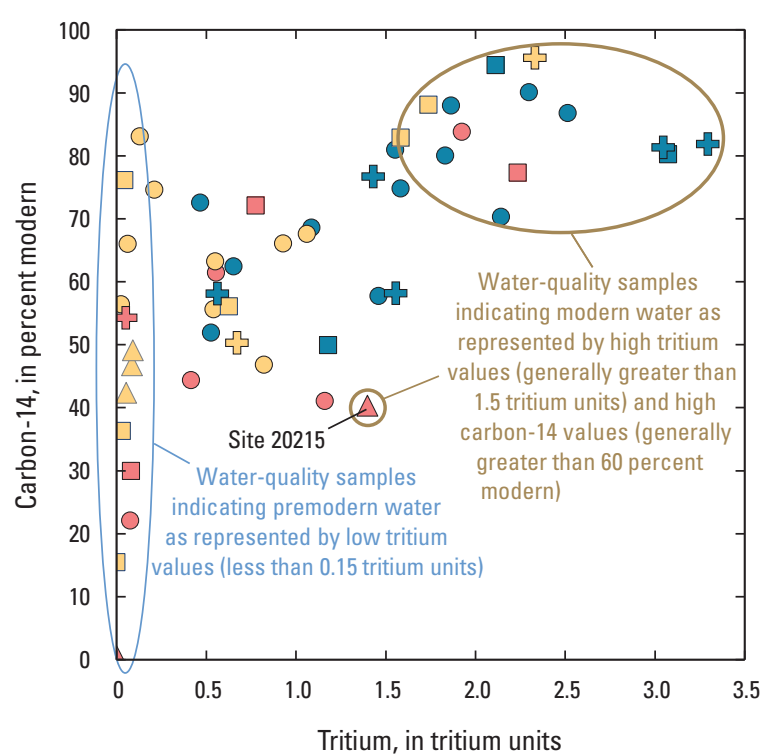

EXPLANATION

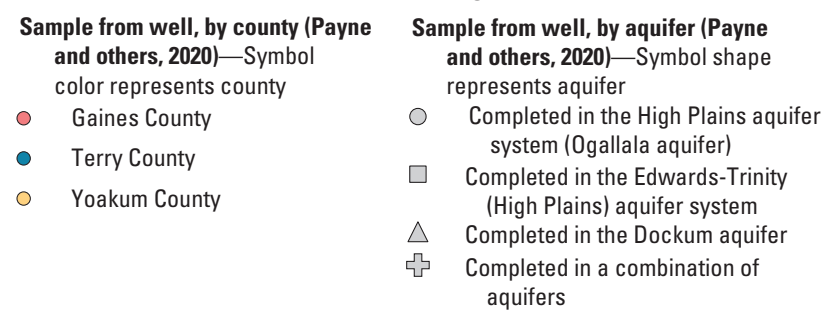

Figure 17. Tritium and carbon-14 concentrations in waterquality samples from groundwater wells in Gaines, Terry, and Yoakum Counties, Texas, 2014 and 2016.

for the Edwards-Trinity (High Plains) and Dockum aquifers were prepared and reviewed for anomalies following methods described in Thomas and others (2016). In areas where anomalies were identified, groundwater-level altitudes were evaluated for consistency with nearby wells completed in the same aquifer. Outlying data were reviewed by comparing them with the original source data. If the original source data were deemed questionable, then the outlying data were removed. The potentiometric-surface map for the Ogallala aquifer was constructed by Brady and Bush (2018) using data collected by the UWCDs; the UWCDs also reviewed and maintained the data for the maps in machine-readable format. All of the data used to construct potentiometric surface maps for this study are provided in the companion data release for this report (Payne and others, 2020).

\section{Regional Groundwater Flow}

Potentiometric-surface maps for the Ogallala, EdwardsTrinity (High Plains), and Dockum aquifers were evaluated for spatial variability in groundwater-level altitudes and regional groundwater-flow paths and gradients (fig. 19). Groundwater-level altitudes for the aquifers are generally higher in the northwestern part of the study area and lower in the southeastern part of the study area. Groundwater-flow paths generally have a northwest to southeast direction across the study area in each of the aquifers.

\section{Ogallala Aquifer}

The 2018 groundwater-level altitudes for the Ogallala aquifer are generally higher in the northwestern part of the study area and lower in the southeastern part of the study area, differing by more than $800 \mathrm{ft}$ (fig. 19A) (Thomas and others, 2016; Brady and Bush, 2018; Payne and others, 2020). Groundwater-flow paths in the Ogallala aquifer follow the regional trend from northwest to southeast. Groundwater in Yoakum County flows towards the east or southeast except for the southwest corner of the county west of Denver City, Tex., where some groundwater flows towards the south (fig. 19A). As groundwater flows from Yoakum County into Terry County, it flows towards the southeast or south; groundwater flows more towards the south approaching the central and eastern part of Terry County (fig. 19A). Groundwater flow in Gaines County is generally towards the southeast; in some areas, flow is slightly to the east or south (fig. 19A).

\section{Edwards-Trinity (High Plains) Aquifer}

The paucity of wells completed in the Edwards-Trinity (High Plains) aquifer made it difficult to obtain a dataset similar to that for the Ogallala aquifer. Because of the small dataset for the Edwards-Trinity (High Plains) aquifer, inferences drawn from the potentiometric surface for this aquifer are more qualitative compared to the inferences drawn from the potentiometric-surface of Ogallala aquifer.

The recent groundwater-level altitudes for the EdwardsTrinity (High Plains) aquifer were greater than $3,700 \mathrm{ft}$ in the northwestern part of the study area (fig. 19B) (Thomas and others, 2016; Payne and others, 2020), and the lowest altitudes were about $3,000 \mathrm{ft}$ along the southeastern extent of the aquifer within the study area. Groundwater-level altitudes decline to the southeast in the Edwards-Trinity (High Plains) aquifer, indicating that groundwater flows from northwest to southeast. Some localized groundwater-flow paths were observed. West of Denver City, Tex., groundwater flows towards the south before flowing towards the east, south of Denver City, Tex. (fig. 19B). Groundwater in the north-central part of the study area flows east from Yoakum County into Terry County, and then flows initially to the southeast towards Brownfield, Tex. (fig. 19B), before transitioning to a more easterly direction. 


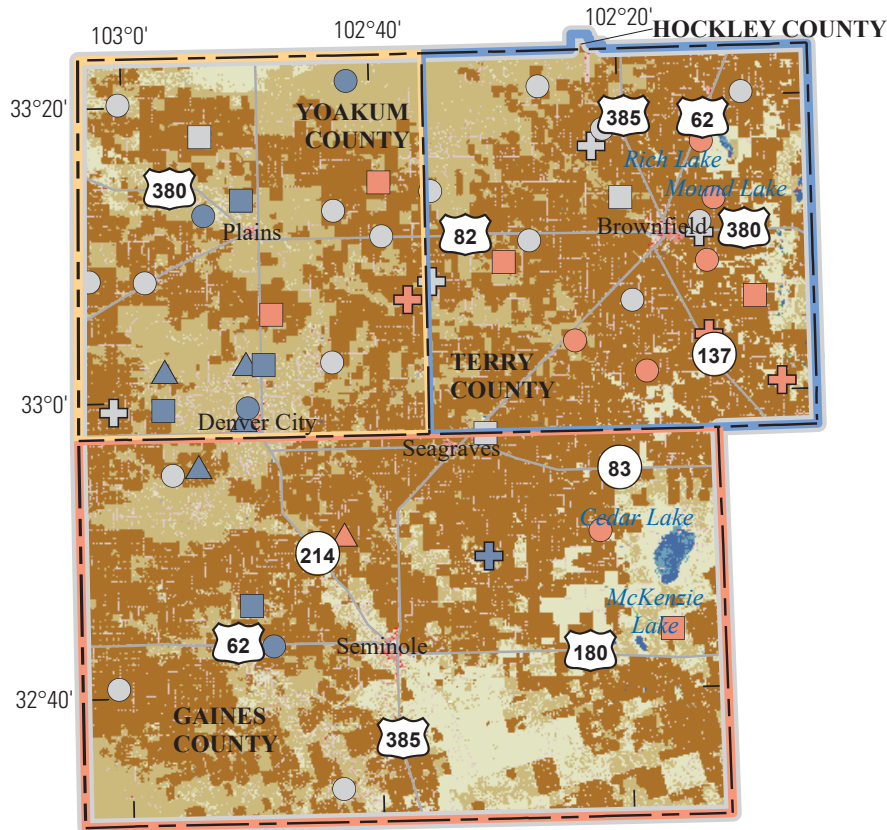

Base from U.S. Geological Survey National Land Cover Database

Universal Transverse Mercator projection, zone 13

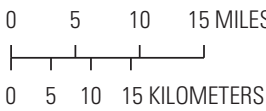

North American Datum of 1983

\section{EXPLANATION}

Land-cover category (Homer and others, 2015)

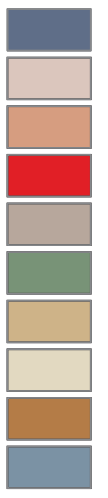

Open water

Developed, open space

Developed, low intensity

Developed, medium intensity

Barren land (rock/sand/clay)

Deciduous forest

Shrub/scrub

Grassland/herbaceous

Cultivated crops

Emergent herbaceous wetland

\section{Study area boundary}

Underground water conservation district boundary

Llano Estacado Underground Water Conservation District Sandy Land Underground Water Conservation District

South Plains Underground

Water Conservation Distric
Sample from well, by age designation (Payne and others, 2020)—Symbol color represents age designation

Modern as represented by high tritium value (generally greater than 1.5 tritium units) and high carbon-14 value (generally greater than 60 percent modern)

Premodern as represented by low tritium value (less than 0.15 tritium units)

Mixed as represented by not being modern or premodern

Sample from well, by aquifer (Payne and others, 2020)—Symbol shape represents aquifer in which well was completed

Completed in the High Plains aquifer system (Ogallala aquifer)

Completed in the Edwards-Trinity (High Plains) aquifer system

$\triangle \quad$ Completed in the Dockum aquifer

گ Completed in a combination of aquifers

Figure 18. Relative ages of groundwater in Gaines, Terry, and Yoakum Counties, Texas, 2014 and 2016. 

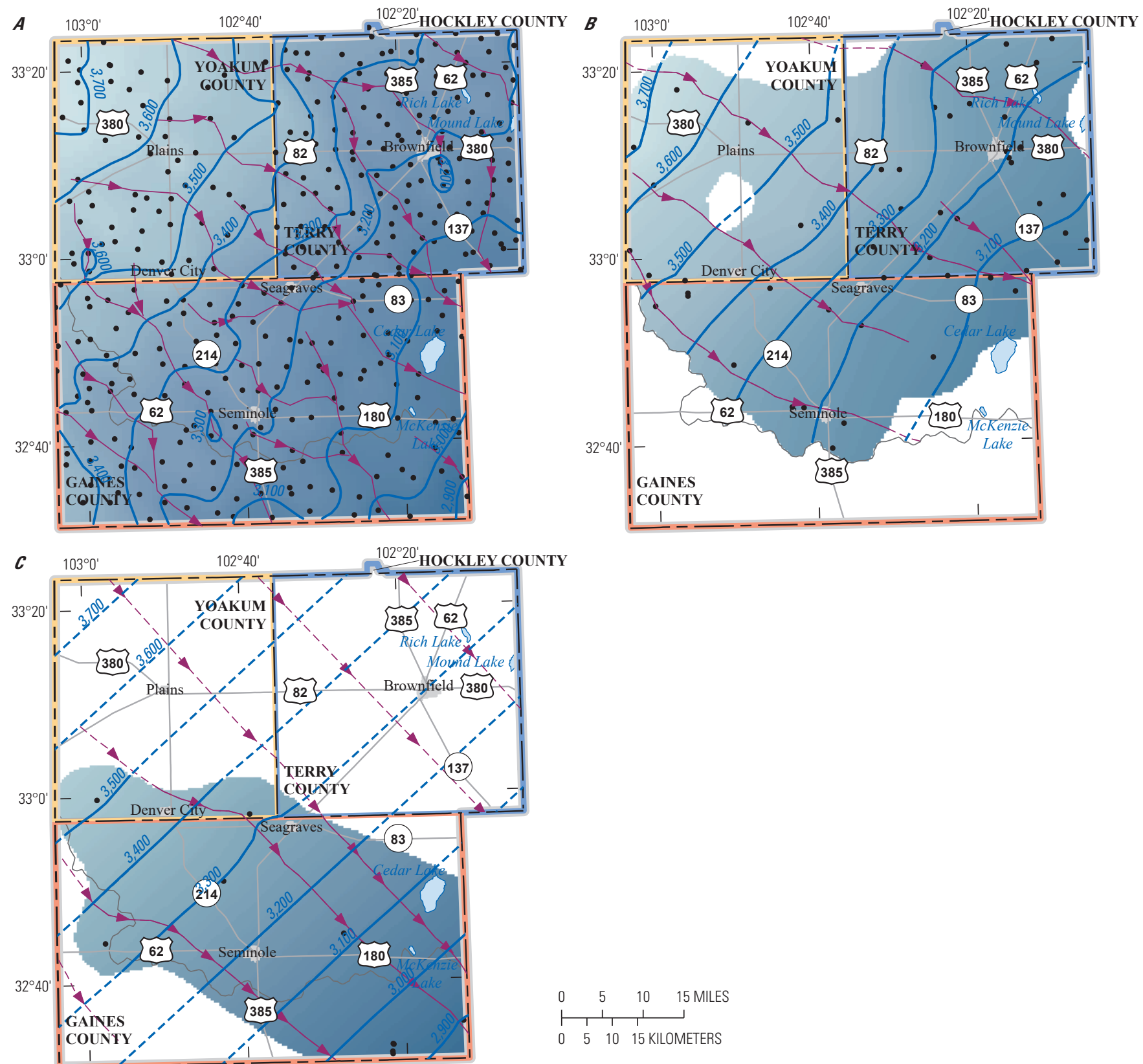

Base modified from U.S. Geological Survey 1:250,000-scale to 1:2,000,000-scale digital data, Universal Transverse Mercator projection, zone 13

North American Datum of 1983

\section{EXPLANATION}

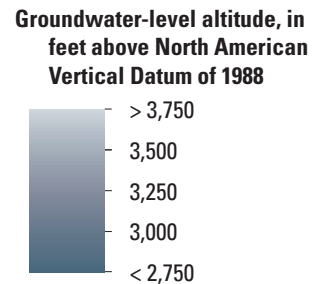
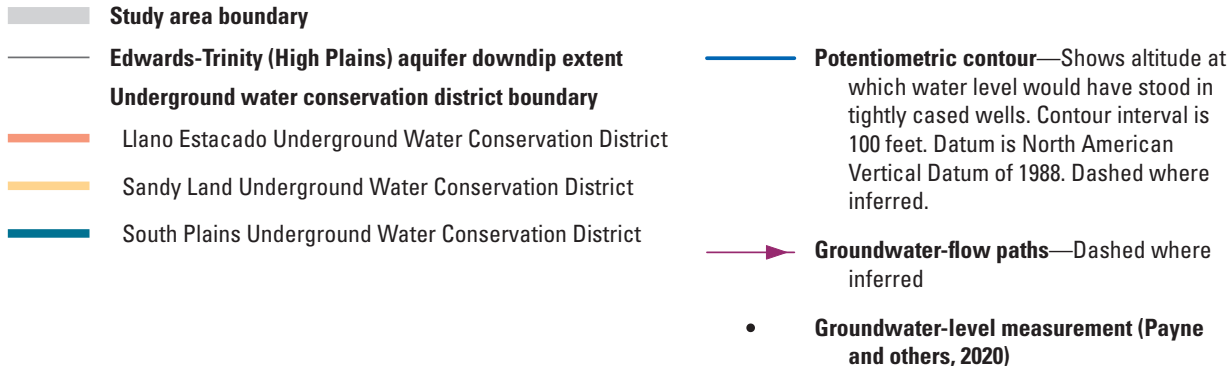

Figure 19. Potentiometric surfaces developed from groundwater-level altitudes measured during the dormant season (November 2017 through April 2018) in wells completed in $A$, the Ogallala aquifer (Brady and Bush, 2018), $B$, the Edwards-Trinity (High Plains) aquifer system, and $C$, the Dockum aquifer in and near Gaines, Terry, and Yoakum Counties, Texas. 


\section{Dockum Aquifer}

The number of wells completed in the Dockum aquifer was substantially less than the number of wells completed in the Ogallala and Edwards-Trinity (High Plains) aquifers. Groundwater-level-altitude data were primarily from wells in Gaines County, with only a couple measurements in the northern part of the study area. The few data that were available were used to provide generalized insights regarding groundwater-flow gradients within the Dockum aquifer.

Similar to the Ogallala and Edwards-Trinity (High Plains) aquifers, groundwater-level altitudes for the Dockum aquifer were highest in the northwest of the data extent, at more than $3,700 \mathrm{ft}$, and lowest in the southeastern Gaines County, at about 2,900 ft (fig. 19C) (Thomas and others, 2016; Payne and others, 2020). This altitude difference indicates regional groundwater-flow paths for the Dockum aquifer are from the northwest to the southeast of the study area (fig. 19C).

\section{Aquifer Hydraulic Properties}

Understanding the hydraulic properties of an aquifer system is critical to characterizing the ability of the system to transmit (transmissivity and hydraulic conductivity) and store (specific yield) water (Lohman, 1979; Heath, 1983; Fetter, 1988). Transmissivity is defined as the rate at which water is transmitted horizontally through a unit width of an aquifer under a unit hydraulic gradient. The hydraulic conductivity, also called the coefficient of permeability, of an aquifer is the transmissivity divided by the aquifer thickness (or saturated thickness if unconfined). Higher hydraulic-conductivity values correlate with higher yields and less drawdown in a well (Heath, 1983). Specific yield is the volumetric fraction of the bulk aquifer volume that a given aquifer will yield when all the water is allowed to drain out of it under the forces of gravity (Bear, 1979). The lower the specific yield, the deeper the drawdown in a well for a given pumping rate (Heath, 1983). Total porosity, the fraction of the soil or rock volume that is occupied by pore space, is the void space of a rock or unconsolidated material and is equal to the specific yield (effective porosity) plus specific retention, or water retained because of capillary or other forces. In general, the total porosity is a measure of the total subsurface water content, effective porosity is the water held in larger pores available for production, and specific retention is water held in smaller pores too tight to produce. Historical aquifer-test data were used in conjunction with borehole EM flowmeter and nuclear magnetic resonance (NMR) measurements and surface geophysical TDEM sounding data collected for this study (fig. 2) to estimate transmissivity and total porosity, which were then used to estimate the hydraulic conductivity and specific yield of the aquifers. All aquifer-test data were in the form of single-well pumping tests rather than the traditional collection of multiple measurements involving several wells (Stallman, 1971).

\section{Data Compilation}

Hydraulic-property data were compiled for the Ogallala, Edwards-Trinity (High Plains), and Dockum aquifers in and near Gaines, Terry, and Yoakum Counties. A 5-mile buffer was created around the study area to prevent gridding errors near the study area boundary. Aquifer-test data collected at more than 1,950 groundwater wells were compiled from databases maintained by the USGS (U.S. Geological Survey, 2020b), the Texas Water Development Board (Texas Water Development Board, 2020c; Texas Water Development Board, 2020d; Texas Water Development Board, 2020e), and SPUWCD (South Plains Underground Water Conservation District, written commun., 2020) and data from Payne and others (2020). Transmissivity of a well was estimated using Driscoll's equation for an unconfined aquifer (Driscoll, 1986, appendix 16D). Driscoll's equation is

$$
T=1,500 \times Q / s
$$

where

$$
\begin{gathered}
T \quad \begin{array}{c}
\text { is transmissivity in gallons per day per foot of } \\
\text { drawdown; }
\end{array} \\
Q \quad \begin{array}{c}
\text { is well yield or pumping rate in gallons per } \\
\text { minute; and }
\end{array} \\
S \quad \begin{array}{l}
\text { is drawdown at any point in the vicinity of a } \\
\text { well discharging at a constant rate in feet. }
\end{array}
\end{gathered}
$$

Transmissivity values were estimated from the historical aquifer-test data that had both a pump rate or yield and a drawdown, using the methods outlined in Bumgarner and others (2012).

\section{Data Collection}

Aquifer tests are done to assess the hydraulic properties of water-bearing and associated rocks (Stallman, 1971). Seven single-well aquifer tests were completed with ambient and pumping borehole EM flowmeter measurements made by the USGS in March 2017 (table 4) (Payne and others, 2020; U.S. Geological Survey, 2020a). Additionally, borehole NMR measurements were made at six wells by the USGS in April 2018 (table 4) (Payne and others, 2020; U.S. Geological Survey, 2020a). Borehole EM induction data were collected at the same wells where the borehole NMR measurements were made (some borehole EM induction logs were made prior to the measurements in August 2012) (table 4). Borehole geophysical tools used in the data collection for this study were interfaced to a Century System VI, a Mount Sopris Matrix, or a Vista Clara Javelin Wireline log-acquisition system. Limitations, calibration procedures, and algorithms of the logging tools are described by the manufacturers (Century Geophysical Corporation, 2020; Mount Sopris Instruments, 2020; Vista Clara Inc., 2020). 
Table 4. Selected well completion information, aquifer designation, borehole geophysical method, and measurement date for borehole geophysical data collected from wells in and near Gaines, Terry, and Yoakum Counties, Texas.

[USGS, U.S. Geological Survey; bls, below land surface; EM, electromagnetic; NMR, nuclear magnetic resonance; OGLL, High Plains aquifer system (Ogallala aquifer); ETHP; Edwards-Trinity (High Plains) aquifer system; DOCK, Dockum aquifer; COMB, Combination; --, no value]

\begin{tabular}{|c|c|c|c|c|c|c|c|c|}
\hline $\begin{array}{c}\text { Site } \\
\text { identifier }\end{array}$ & USGS well number & County & $\begin{array}{c}\text { Well } \\
\text { depth } \\
\text { (feet bls) }\end{array}$ & $\begin{array}{l}\text { Screened } \\
\text { or open } \\
\text { interval } \\
\text { (feet bls) }\end{array}$ & $\begin{array}{l}\text { Aquifer } \\
\text { in which } \\
\text { the well is } \\
\text { completed }\end{array}$ & $\begin{array}{c}\text { Aquifer } \\
\text { designation }\end{array}$ & $\begin{array}{l}\text { Geophysical } \\
\text { method }\end{array}$ & $\begin{array}{l}\text { Measurement } \\
\text { date }\end{array}$ \\
\hline 02099 & 324151102175901 & Gaines & 210 & -- & DOCK & DOCK & $\begin{array}{l}\text { EM induction, } \\
\text { NMR }\end{array}$ & $\begin{array}{c}2 / 12 / 2014 \\
4 / 6 / 2018\end{array}$ \\
\hline 02207 & 325034102215501 & Gaines & 80 & -- & OGLL & OGLL & EM induction & $2 / 12 / 2014$ \\
\hline 02342 & 324006102223901 & Gaines & 132 & -- & DOCK & DOCK & EM induction & $4 / 3 / 2013$ \\
\hline 02408 & 324035102243801 & Gaines & 118 & $58-118$ & OGLL & OGLL & EM induction & $4 / 3 / 2013$ \\
\hline 02455 & 324000102223501 & Gaines & 118 & -- & OGLL & OGLL & EM induction & $4 / 3 / 2013$ \\
\hline 02508 & 324025102242001 & Gaines & 116 & -- & OGLL & OGLL & EM induction & $4 / 3 / 2013$ \\
\hline 02985 & 323840102275101 & Gaines & 187 & $145-187$ & $\begin{array}{l}\text { OGLL; } \\
\text { DOCK }\end{array}$ & COMB & EM induction & $4 / 3 / 2013$ \\
\hline 03074 & 323246102333401 & Gaines & 130 & $50-130$ & OGLL & OGLL & EM induction & $4 / 4 / 2013$ \\
\hline 03698 & 323247102335501 & Gaines & 145 & -- & OGLL & OGLL & EM induction & $4 / 4 / 2013$ \\
\hline 04563 & 323254102314501 & Gaines & 124 & $50-124$ & $\begin{array}{l}\text { OGLL; } \\
\text { DOCK }\end{array}$ & COMB & EM induction & $4 / 4 / 2013$ \\
\hline 05090 & 325431102215901 & Gaines & 108 & $78-108$ & $\begin{array}{l}\text { OGLL; } \\
\text { ETHP }\end{array}$ & COMB & EM induction & $4 / 4 / 2013$ \\
\hline 06427 & 324337102315801 & Gaines & 163 & -- & DOCK & DOCK & EM induction & $4 / 4 / 2013$ \\
\hline 10091 & 331615102351001 & Terry & 119 & -- & OGLL & OGLL & $\begin{array}{l}\text { EM induction, } \\
\text { EM flowmeter }\end{array}$ & $\begin{array}{l}8 / 21 / 2012 \\
3 / 16 / 2017\end{array}$ \\
\hline 10118 & 331756102213501 & Terry & 370 & $\begin{array}{l}110-160 \\
330-370\end{array}$ & $\begin{array}{l}\text { OGLL; } \\
\text { ETHP }\end{array}$ & COMB & EM induction & $3 / 28 / 2012$ \\
\hline 10446 & 330554102081101 & Terry & 260 & $60-260$ & ETHP & ETHP & $\begin{array}{l}\text { EM induction, } \\
\text { EM flowmeter }\end{array}$ & $\begin{array}{l}3 / 29 / 2012 \\
3 / 18 / 2017\end{array}$ \\
\hline 10793 & 325755102232901 & Terry & 270 & $100-270$ & $\begin{array}{l}\text { OGLL; } \\
\text { ETHP }\end{array}$ & COMB & EM induction & $3 / 29 / 2012$ \\
\hline 11025 & 324659102423401 & Gaines & 207 & 107-207 & $\begin{array}{l}\text { OGLL; } \\
\text { ETHP }\end{array}$ & COMB & EM induction & $8 / 23 / 2012$ \\
\hline 11071 & 324623102321401 & Gaines & 211 & $86-211$ & $\begin{array}{l}\text { OGLL; } \\
\text { ETHP }\end{array}$ & COMB & EM induction & $4 / 4 / 2013$ \\
\hline 11111 & 325033102192701 & Gaines & 82 & -- & OGLL & OGLL & EM induction & $4 / 4 / 2013$ \\
\hline 11349 & 324243102245701 & Gaines & 117 & $26-117$ & $\begin{array}{l}\text { OGLL; } \\
\text { ETHP }\end{array}$ & COMB & EM induction & $4 / 2 / 2013$ \\
\hline 11520 & 323720102245701 & Gaines & 125 & -- & DOCK & DOCK & EM induction & $4 / 2 / 2013$ \\
\hline 11541 & 323455102285901 & Gaines & 127 & -- & DOCK & DOCK & EM induction & $4 / 3 / 2013$ \\
\hline 11542 & 323402102260401 & Gaines & 149 & -- & OGLL & OGLL & EM induction & $4 / 2 / 2013$ \\
\hline 11642 & 330037102071801 & Terry & 250 & $210-250$ & $\begin{array}{l}\text { ETHP; } \\
\text { DOCK }\end{array}$ & COMB & EM induction & $8 / 22 / 2012$ \\
\hline 11643 & 330037102073801 & Terry & 210 & $170-210$ & ETHP & ETHP & $\begin{array}{l}\text { EM induction, } \\
\text { EM flowmeter }\end{array}$ & $\begin{array}{l}8 / 22 / 2012 \\
3 / 20 / 2017\end{array}$ \\
\hline 11644 & 331410102281601 & Terry & 358 & $155-358$ & $\begin{array}{l}\text { ETHP; } \\
\text { DOCK }\end{array}$ & COMB & $\begin{array}{l}\text { EM induction, } \\
\text { EM flowmeter }\end{array}$ & $\begin{array}{l}8 / 21 / 2012 \\
3 / 17 / 2017\end{array}$ \\
\hline 11650 & 323243102452501 & Gaines & 1,720 & $920-1,720$ & DOCK & DOCK & EM induction & $8 / 23 / 2012$ \\
\hline
\end{tabular}


Table 4. Selected well completion information, aquifer designation, borehole geophysical method, and measurement date for borehole geophysical data collected from wells in and near Gaines, Terry, and Yoakum Counties, Texas._-Continued

[USGS, U.S. Geological Survey; bls, below land surface; EM, electromagnetic; NMR, nuclear magnetic resonance; OGLL, High Plains aquifer system (Ogallala aquifer); ETHP; Edwards-Trinity (High Plains) aquifer system; DOCK, Dockum aquifer; COMB, Combination; --, no value]

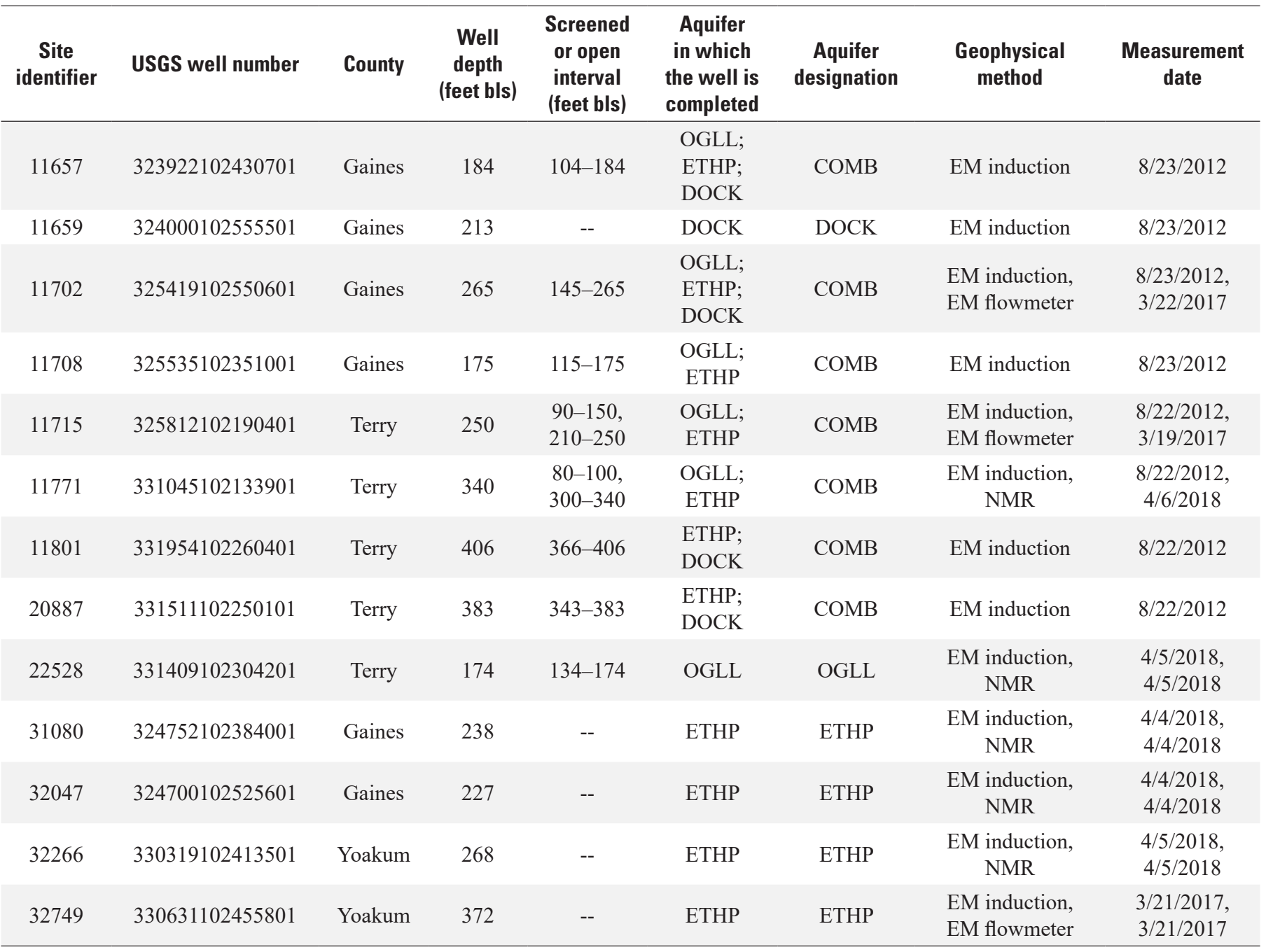

Borehole geophysical data collection by the USGS followed ASTM borehole geophysical standard procedures (American Society of Testing and Materials, 2004; American Society of Testing and Materials, 2007; American Society of Testing and Materials, 2010). During collection, the data were recorded in binary formats by their appropriate log-acquisition system and were converted to, and archived as, Log American Standard Code for Information Interchange Standard (LAS) files (Canadian Well Logging Society, 2020) for tabular data and presented as chart logs in Portable Document Format (PDF). The LAS, PDF, original binary, and image files of the borehole data are available on the USGS GeoLog Locator (U.S. Geological Survey, 2020a).

\section{Borehole Electromagnetic Flowmeter}

The EM flowmeter measures the rate and direction of vertical flow in a borehole by using the principle of Faraday's law of induction. Comprehensive descriptions of the theory and application of EM flowmeter are presented in Kaufman and Dashevsky (2003) and Kaufman and Itskovich (2017). The EM flowmeter data were collected in the boreholes at various stationary locations throughout the water column and by raising and lowering the EM flowmeter through the length of the water column, following a methodology similar to that described in Thomas and others (2012). Stationary and moving EM flowmeter data were collected during ambient and stressed, or pumping, conditions. When possible, EM flowmeter data were collected at the same depths during ambient and stressed conditions. 


\section{Borehole Nuclear Magnetic Resonance Sounding}

Borehole NMR is a non-invasive geophysical technique that directly measures water content in the subsurface by detecting the behavior of water responding to magnetic fields applied by the borehole geophysical tool (Kenyon and others, 1995). NMR data were used to define properties of the aquifers and to measure total porosity, effective porosity, and specific retention in the study area. The principles and applications of the NMR method are summarized by Weichman and others (2000), Legchenko and others (2006), Plata and Rubio (2008), Walbrecker and others (2009), Walsh and others (2013), and Kass and others (2014).

The NMR geophysical tool used for this investigation was a wireline Javelin JPX-350 developed by Vista Clara Inc. (Vista Clara Inc., 2020). The tool is approximately 15 feet long and has a diameter of 3.5 inches. The diameter of sensitivity of the instrument ranges from 10 to 15 inches from the center of the tool; the well construction must be considered so as not to include the annular space in the measurement. Because the NMR instrument detects water content through the manipulation of magnetic fields, any metallic material within the immediate vicinity of the instrument, such as steel casing or centralizers will also render the measurements from the tool unusable in that area. Open-hole wells with a diameter of 4 to 8 inches were targeted for data collection. Because few open-hole wells were available in the study area, polyvinyl chloride (PVC) cased wells were primarily used for the NMR data collection.

For this study, continuous data collection techniques were utilized; vertical resolution is spread out across the traveled distance of the logging tool throughout the depth of the well during data collection, which was done by using traversal rates of about 100 to 160 feet per hour as recommended by the tool manufacturer (Vista Clara Inc., 2020). Vertical resolution for the NMR logs in this study ranges from 1.5 to 5.0 feet. The logging tool measured the magnitude and rate of the $T_{2}$ decay, the signal response associated with the $\mathrm{T}_{2}$ relaxation time. The $\mathrm{T}_{2}$ relaxation time is a time constant that is associated with the decay of the magnetized field in the direction perpendicular to the background field (Dlubac and others, 2013). The magnitude of the $\mathrm{T}_{2}$ decay is directly proportional to the amount of water in the measurement area (Hull and others, 2019). The rate of the $T_{2}$ decay indicates the relative pore size distribution in the measurement area, with faster $T_{2}$ decays related to smaller pore size. The data collection methods are similar to those described in Hull and others (2019).

\section{Borehole Electromagnetic Induction}

EM induction tools measure conductivity in air- or water-filled wells and are effective in open-hole or PVC-cased wells. Explanation of how conductivity values are computed from EM induction tools is provided by Keys (1997). The measurement of conductivity commonly is reciprocated to provide logs with curves of resistivity and conductivity (Keys, 1997). A Century Geophysical Corporation 9510 or a Century Geophysical Corporation 9512 EM induction conductivity probe was calibrated and used to the manufacturer's specifications (Century Geophysical Corporation, 2020). Evaluation of the induction data from the Century Geophysical Corporation 9510 tool revealed lower than expected values, so the instrument was recalibrated. The original values from the Century Geophysical Corporation 9512 EM induction tool and the recalibrated values from the Century Geophysical Corporation 9510 EM induction tool were used find a correlation between resistivity and total porosity from the borehole NMR. The borehole EM induction results were systematically corrected to a temperature of $77^{\circ} \mathrm{F}\left(25^{\circ} \mathrm{C}\right)$.

\section{Methods}

After data compilation and collection, the data needed to be processed further to obtain the desired aquifer properties of hydraulic conductivity and specific yield. The compiled historical aquifer-test data and the borehole EM flowmeter data were used to estimate the hydraulic conductivity, and the borehole NMR was used to estimate hydraulic conductivity and specific yield. The surface geophysical TDEM data were used to estimate the specific yield.

\section{Compiled Data}

Hydraulic-conductivity values were estimated from the historical aquifer-test data. If a groundwater-level measurement was made in conjunction with the historical aquifer-test data, that groundwater-level measurement was used with the well completion data to determine the saturated thickness of the aquifer. The saturated thickness obtained during the aquifer test can be described by one of four scenarios: (1) the well opening, or screened interval, is contained within the saturated part of the aquifer making the saturated thickness the length of the well opening, or screened interval; (2) the water table is above the well opening, or screened interval, and the base of the aquifer is within the well opening, or screened interval, making the saturated thickness the difference between the altitude of the top of the well opening and the altitude of the base of the aquifer; (3) the water table is within the well opening, or screened interval, and the base of the aquifer is below the well opening, or screened interval, making the saturated thickness the difference between the altitude of the water table and the altitude to the bottom of the well opening, or screened interval; and (4) the entire saturated part of the aquifer is contained within the well opening, or screened interval, making the saturated thickness the difference between the water-table altitude and the altitude of the base of the aquifer. The hydraulic conductivities were computed by dividing the transmissivity by the saturated thickness determined from one of the four scenarios. In the case of the second and fourth scenarios, there 
would be an influence from another geologic formation, so the hydraulic conductivities were noted to come from a combination of aquifers and were not used for the analysis.

If the historical aquifer-test data did not include a groundwater-level measurement, the date of the aquifer test was used to estimate the groundwater-level at the time of the test. First, all the historical groundwater-level measurements at the aquifer-test wells were evaluated. If a groundwater-level measurement made within 1 year prior to or after the aquifertest date was available (wells are typically measured annually in the study area, so the closest temporal measurements should be about 1 year apart), that groundwater-level measurement was used to estimate the saturated thickness for the aquifer-test data. If there were no groundwater-level measurements within this 2-year timeframe for the well, then a median groundwaterlevel altitude was computed on the basis of measurements made for the 10 nearest wells. The median groundwater-level altitude was then used to estimate the saturated thickness for the aquifer-test data. The hydraulic-conductivity value was then computed by using this estimated saturated thickness value.

Some of the historical aquifer-test data were collected over multiple years from the same wells, resulting in multiple hydraulic-conductivity values for these wells. In theory, hydraulic conductivity should not change over time as long as the physical conditions of the soil and water do not change (Kirkham, 2014), but in practice, the hydraulic conductivity can change slightly over time because of chemical and physical processes such as ion exchange processes, changes in chemical concentrations in the water, swelling of clay, and migration of clay particles (Hillel, 2008). In most cases, when there were multiple hydraulic-conductivity values for a given well, most of the hydraulic-conductivity values were relatively similar (within about one order of magnitude). Although the hydraulic-conductivity values were relatively similar, the hydraulic-conductivity values collected most recently were used in the final analysis for wells where aquifer tests were completed over multiple years. Because hydraulic conductivity is not expected to change appreciably over time, a dataset with a large time range should not skew the results.

\section{Borehole Flowmeter}

To process the borehole EM flowmeter data and compute different zones of transmissivity and hydraulic heads for the open section of the borehole, the Flow-Log Analysis of Single Holes (FLASH) numerical model was used (Day-Lewis and others, 2011), which is similar to the numerical model used in Thomas and others (2012). FLASH produces multilayered models utilizing the Thiem equation to create an analytical solution for steady-state flow in a borehole (Day-Lewis and others, 2011). FLASH generates numerical borehole flow data representing the theoretical flow that would be measured in a borehole given a specified number of transmissive zones and head values for parts of the aquifer not affected by nearby pumping. Several hydraulic properties, including total transmissivity or radius of influence (the distance for which the well can affect or be affected by its surroundings), are entered into FLASH to solve the multilayered model and compute the output values (transmissivities and hydraulic heads) for each transmissive zone. For this study, an estimated total transmissivity, based on the difference in measured drawdown between ambient and pumping conditions and computed using Driscoll's equation, was used to model the radius of influence (Driscoll, 1986, appendix 16D).

The total transmissivity for an aquifer was obtained by adding the transmissivity from each modeled zone within the aquifer. The total transmissivity was then divided by the saturated thickness of the aquifer, using the groundwater-level measurement made prior to flowmeter data collection, to get a hydraulic-conductivity value for the aquifer.

\section{Borehole Nuclear Magnetic Resonance}

The NMR method, which measures the response of the water molecules directly, was used to estimate the hydraulic conductivity and the specific yield of the aquifer simultaneously. The NMR data were processed using the manufacturer's software (Vista Clara Javelin ProPlus version 3.7). Frequency measurements containing greater than 15 -percent residual noise were removed. The $\mathrm{T}_{2}$-decay data from the resulting frequency measurements were filtered using an impulse noise filter and were adjusted by removing the ambient noise, collected with an external reference coil, measured concurrently at the land surface. Depth-averaging over three measurements was applied to smooth the data and dampen the effects of any suspicious measurements. The four frequency measurements for each $\log$ in the study were "noise-stacked," meaning that they were combined in proportion to their relative noise. After the frequency data were combined, the resultant $T_{2}$ decay was modeled with a multiexponential decay curve. The modeling results produce a pore-size distribution model shown as a fraction of the total water content, which is the sum of the mobile-, capillary-, and bound-water fractions. The mobile-, capillary-, and bound-water fractions (fractions of the total porosity) were determined by using empirically derived cutoff values of $\mathrm{T}_{2}$ relaxation times (Straley and others, 1997). Software defaults for capillary- and bound-water are 33 and 4 milliseconds, respectively, and are generally accepted as robust cutoff values (Timur, 1969; Walsh and others, 2013; Behroozmand and others, 2015).

Hydraulic-conductivity values were estimated from the NMR data by using the Schlumberger-Doll research equation (Kenyon and others, 1988). Because the borehole NMR method is not limited to the open section of the well, the average hydraulic-conductivity value for the saturated part of the aquifer, regardless of well opening or screened interval, was used to represent the hydraulic conductivity of the aquifer at the well location. The average mobile-water fraction of the total porosity for the saturated part of the aquifer, regardless of well opening or screened interval, was used to represent the specific yield of the aquifer at the well location. 


\section{Time-Domain Electromagnetic Soundings}

A set of processes was needed to convert bulk resistivity from the TDEM to specific yields. Resistivity was related to total porosity by using Archie's equation to form a regression between the borehole EM induction and borehole NMR data, and specific yield was estimated from total porosity by applying a factor found from the borehole NMR data. Fluid resistivity is needed for Archie's equation, so historical specific conductivity values from water-quality data were used to estimate the fluid resistivity throughout the study area.

\section{Resistivity and Total Porosity Regression Equation}

Because of the relatively extensive spatial extent of the TDEM data relative to other data types that can be used to derive specific yield, the inverse modeling results of the TDEM data were used to provide a rough estimate of the specific yield throughout the study area. In order for TDEM data to provide useful specific yield estimates, a meaningful correlation must exist between bulk resistivity and total porosity. The total porosity, as opposed to the effective porosity, was used for statistical analysis because the TDEM soundings measure bulk resistivity of the subsurface, which would include all components of the total porosity. Archie (1952) shows a relation between porosity $(\Phi)$ and the formation factor (F) of the subsurface, which is the bulk resistivity of the subsurface divided by the fluid resistivity. For the scenario where the subsurface is filled with water only (as opposed to hydrocarbons or other fluids), Archie's equation reduces to

$$
F=\frac{a}{\Phi^{m}}
$$

where

$$
\begin{aligned}
& a \quad \text { is the tortuosity factor and } \\
& m \quad \text { is the cementation exponent; both constants } \\
& \text { are unitless. }
\end{aligned}
$$

Using Archie's equation, the borehole NMR total porosity results, the borehole EM induction results, and the fluid conductivity (inverse of resistivity) results were used to determine the relation between the formation factor (the borehole EM induction divided by the fluid resistivity) and total porosity. Fitting a non-linear curve using the power equation to the borehole NMR porosity and the formation factor, a regression equation was found for each hydrogeologic unit in the study area (fig. 20). The hydrogeologic unit was used in the analysis instead of the individual aquifers because of the contrast of geologic material between the Trinity and Fredericksburg Groups. The goodness-of-fit of the regression models, as indicated by the R-squared (coefficient of determination; $\mathrm{R}^{2}$ ) values (Helsel and others, 2020), of the Dockum Group (R2 value of 0.2133 ), Fredericksburg Group ( $\mathrm{R}^{2}$ value of 0.3892 ), and Ogallala Formation ( $\mathrm{R}^{2}$ value of 0.2566 ) are fair considering Archie's equation was developed for a clean, consolidated sand. The fit of the regression model of the Trinity Group ( $\mathrm{R}^{2}$ value of 0.0791 ) is poor. A different regression equation should be used to estimate the total porosity for all geologic formations within the study area considering the effect of clays and carbonates on estimating the porosity from resistivity (Crain, 2019). However, because of the lack of a sediment grain-size analysis to provide estimates of tortuosity factor and cementation exponent, and because of the lack of additional information to fulfill the variables found in equations such as the Waxman-Smits equation (Waxman and Smits, 1968) or others listed in Kadhim and others (2013), the relation derived from the Archie's equation was used for a rough estimate of total porosity in the study area. Computing the estimated total porosity values from the regression equations and comparing them with the measured total porosity values from the borehole NMR, the resulting correlation fit is fair (0.1896) with the expected one-to-one relation between the measured and the estimated results (fig. 21).

\section{Effective Porosity and Total Porosity Regression}

Effective porosity values were estimated by using regression models developed between the total porosity and the mobile-water fraction of the total porosity measured from the borehole NMR results. Fitting a straight line to the total porosity and the mobile-water fraction of the total porosity, a linear regression equation was computed for each geologic formation in the study area (fig. 22). The goodness-of-fit values of the regression models of the Dockum Group ( $\mathrm{R}^{2}$ value of 0.6872 ), Trinity Group ( $\mathrm{R}^{2}$ value of 0.6877 ), and Ogallala Formation $\left(R^{2}\right.$ value of 0.5140$)$ are good; the fit of the Fredericksburg Group ( $\mathrm{R}^{2}$ value of 0.0160 ) is poor. The slope of the regression equation of the Fredericksburg Group was near 0 (0.0847), indicating a near constant value of effective porosity for all measured total porosity values. Therefore, the estimated effective porosity for the Fredericksburg Group was set as 0.01 on the basis of the average effective porosity values from the borehole NMR results after removing high effective porosity outliers (greater than 0.05) from the dataset.

Absolute differences between the measured mobilewater fraction of the total porosity and the estimated effective porosity were plotted against formation factor. The lower the formation factor, the higher the variability (fig. 23). When the formation factor is less than 4 , the maximum variability (disregarding outliers represented as the highest 5 percent of values) in the differences between the measured mobile-water fraction of the total porosity and the estimated effective porosity was about 0.15 (unitless), whereas when the formation factor is equal to or greater than 4 , the maximum variability (disregarding the highest 5 percent of values) in the differences between the measured mobile-water fraction of the total porosity and the estimated effective porosity was about 0.05 (unitless). Generally, the more accurate estimates of effective porosity are in locations where the formation factor is higher. For formation factors of less than 4, the preponderance of fine-grained sediments such as silts and clays can make it hard to distinguish between fine-grained sediments and saturated sediments with low fluid resistivity. The lack of ability to distinguish between fine-grained sediments and saturated sediments with 


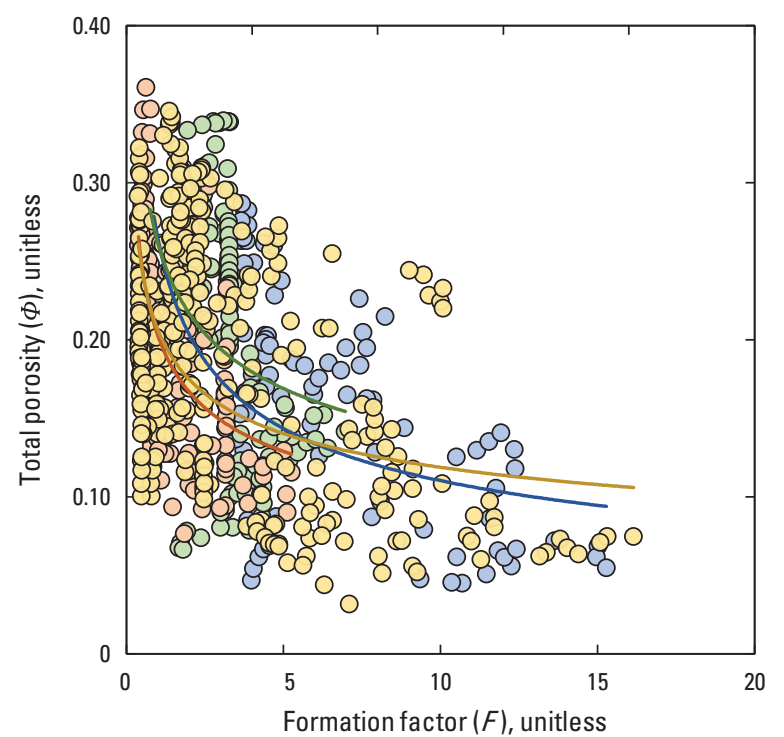

EXPLANATION

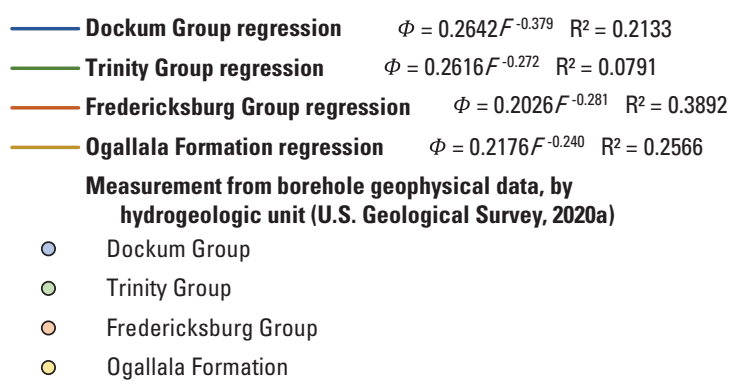

Figure 20. Relation between the borehole nuclear magnetic resonance total porosity and the formation factor computed from the borehole electromagnetic induction and fluid conductivity logs for wells in Gaines, Terry, and Yoakum Counties, Texas, 2012-18. ( $\mathrm{R}^{2}$ is the coefficient of determination.)

low fluid resistivity results in less accuracy with a low formation factor. The formation factor was used to estimate the variability of the effective porosity (effective porosity variability values) for the study area aquifers. The effective porosity variability values represent a value range (plus or minus) from the estimated effective porosity at any location.

\section{Application of Regression Equations to the Time-Domain Electromagnetic Sounding Data}

The TDEM resistivity soundings were temperature corrected by comparing the inverse modeling results with the borehole EM induction logs. TDEM inverse modeling results were also corrected for the geothermal gradient (Nathenson and Guffanti, 1988). The temperature at depth was estimated by using a surface temperature set as the monthly average air temperature during the month that the data were collected (National Oceanic and Atmospheric Administration, 2020) and a subsurface gradient of $77^{\circ} \mathrm{F}$ per $3,280 \mathrm{ft}\left(25^{\circ} \mathrm{C}\right.$ per 1 kilometer) (Nathenson and Guffanti, 1988). The inverse

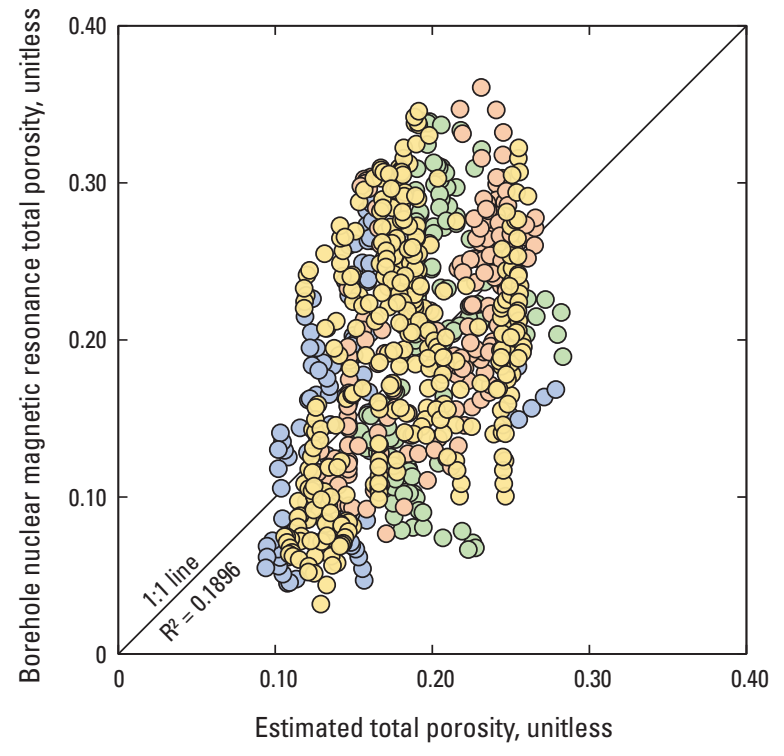

EXPLANATION

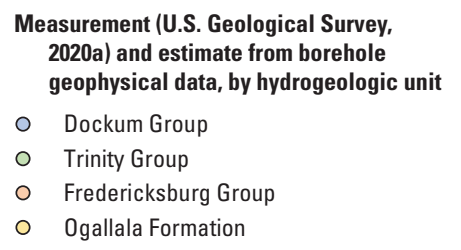

Figure 21. Relation between the borehole nuclear magnetic resonance total porosity and the estimated total porosity from the formation factor computed from the borehole electromagnetic induction and fluid conductivity logs for wells in Gaines, Terry, and Yoakum Counties, Texas, 2012-18. ( $R^{2}$ is the coefficient of determination.)

modeling results of the TDEM soundings were adjusted according to Arps equation (Arps, 1945; Arps, 1956) using these temperatures.

The borehole EM induction results were compared to the nearest temperature corrected inverse modeling results of the TDEM soundings to ensure that the results from the TDEM soundings could be used to estimate effective porosity from a regression model of the borehole EM induction results. This comparison showed that the median difference between the borehole EM induction and the temperature corrected inverse modeling results of the TDEM was about -0.7 ohm-meters (ohm-m). The interquartile range of the differences was -13.9 to $8.9 \mathrm{ohm}-\mathrm{m}$. The interquartile range shows that there is some variability between the borehole EM induction and the temperature corrected inverse modeling results of the TDEM soundings, but the regression fit is considered reasonable by the authors. The observed variability is most likely a result of the high vertical resolution of the borehole EM induction with depth relative to the bulk resistivity with depth from the TDEM soundings. At higher resistivities (where most of the variability is observed), the effect on the effective porosity is minimal (plus or minus 0.05). 


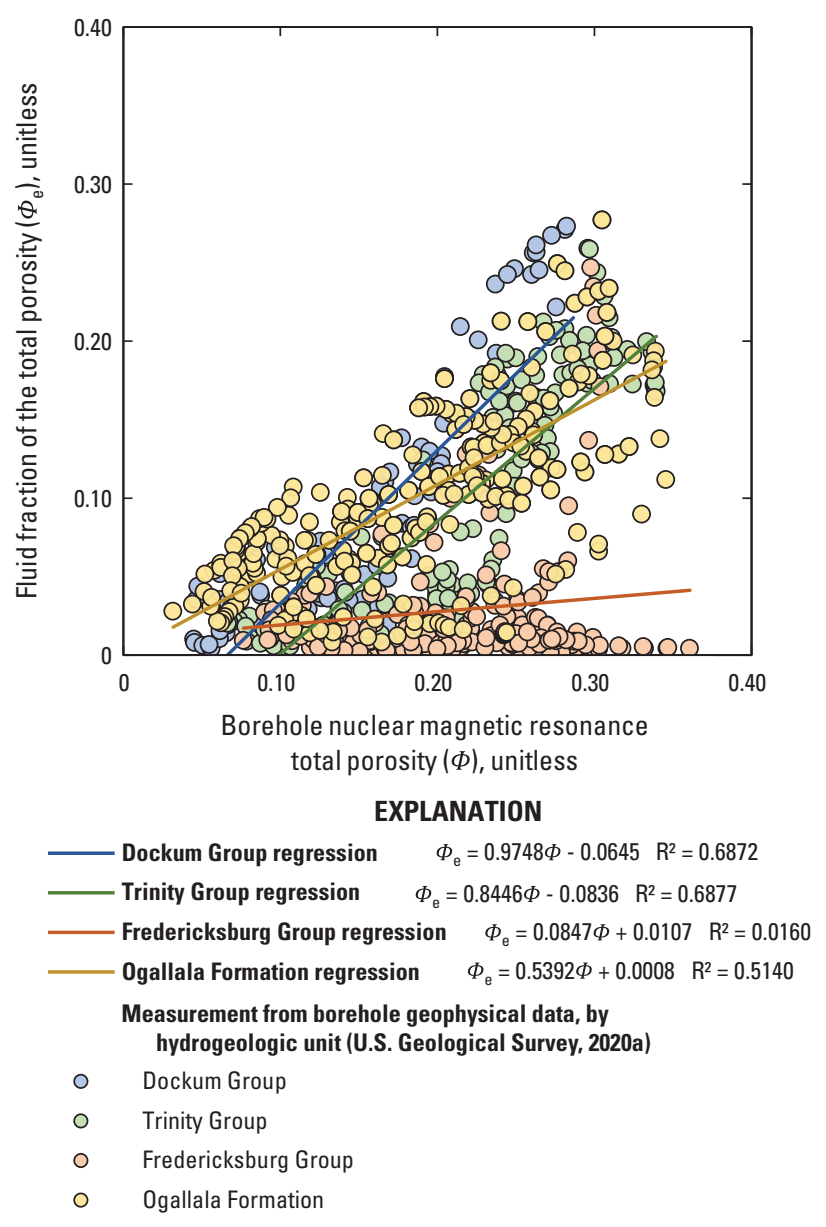

Figure 22. Relation between the borehole nuclear magnetic resonance total porosity and fluid fraction of the total porosity for wells in Gaines, Terry, and Yoakum Counties, Texas, 2012-18. ( $\mathrm{R}^{2}$ is the coefficient of determination.)

A fluid resistivity is needed to compute the formation factor at each TDEM location. Specific conductance values compiled using the historical water-quality data (Payne and others, 2020) were used to estimate the fluid resistivity throughout the study area. All specific conductance values measured during the time period of this study were used. An analysis of historical specific conductance values with depth showed that there was very little variability as a function of depth within the top $500 \mathrm{ft}$ below land surface at any given location. There was more variability as a function of geographic location than depth, an assertion confirmed with the specific conductance measurements made in conjunction with the water-quality sampling and the borehole fluid conductivity data collected during this study. Because of the lack of change with depth, a grid of the specific conductance values at less than a depth of $500 \mathrm{ft}$ was used to represent fluid resistivity throughout the study area. The median specific conductance value for each well was computed, and then a grid was developed by using the kriging method as described in Thomas and others (2019, p. 8); a larger $16,400-\mathrm{ft}$ by $16,400-\mathrm{ft}(5,000-\mathrm{m}$ by $5,000-\mathrm{m})$

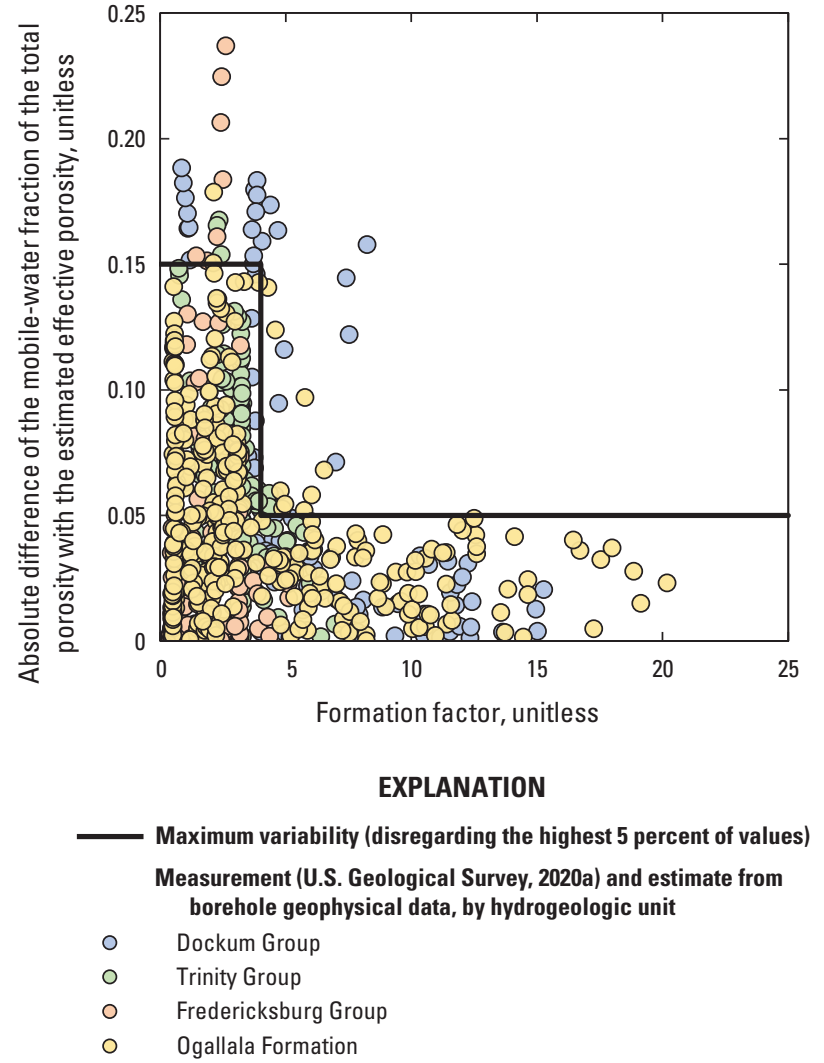

Figure 23. Relation between the absolute difference of the mobile-water fraction of the borehole nuclear magnetic resonance total porosity with the estimated effective porosity and the formation factor for wells in Gaines, Terry, and Yoakum Counties, Texas, 2012-18.

cell size was used, although a cell size of $1,640 \mathrm{ft}$ by $1,640 \mathrm{ft}$ $(500 \mathrm{~m}$ by $500 \mathrm{~m}$ ) was used in other surfaces in this report because of the coarse spacing of the data available for this analysis. The grid was sampled for the specific conductance value at each TDEM sounding location; the specific conductance value was converted to a fluid resistivity value and used to compute the formation factor from the inverse modeling results of the TDEM sounding data.

Effective porosity and effective porosity variability values were estimated by using the formation factor computed from the inverse modeling results of the TDEM sounding data. Values greater than the water-table altitude (at the time of TDEM data collection) were ignored in the analysis. A depth-weighted average of the effective porosity and effective porosity variability values was computed from the inverse modeling results of the TDEM sounding data for each aquifer in each TDEM sounding. The estimated effective porosity and effective porosity variability were used to estimate the specific yield and the specific yield variability values for the study area aquifers. The specific yield variability represents a value range (plus or minus) from the estimated specific yield at any location. 


\section{Hydraulic Conductivity, Specific Yield, and Specific Yield Variability}

The hydraulic-conductivity values computed for each aquifer from historical aquifer-test, borehole EM flowmeter, and borehole NMR data were gridded for the Ogallala, Edwards-Trinity (High Plains), and Dockum aquifers (fig. 24). The same was done for the specific yield and specific yield variability values for each aquifer; specific yield was computed from the borehole NMR and the inverse modeling results of the surface geophysical TDEM sounding data (fig. 25). The kriging method as described in Thomas and others $(2019$, p. 8$)$ was used with a $16,400-\mathrm{ft}$ by $16,400-\mathrm{ft}$ (5,000-m by $5,000-\mathrm{m})$ cell size for the hydraulic conductivity grids and a $1,640-\mathrm{ft}$ by $1,640-\mathrm{ft}(500-\mathrm{m}$ by $500-\mathrm{m})$ cell size for the specific yield grids to account for the spacing of the data, especially the lack of hydraulic-conductivity values for Edwards-Trinity (High Plains) and Dockum aquifers.

\section{Ogallala Aquifer}

The hydraulic-conductivity values of the Ogallala aquifer range from about 0.55 to about 350 feet per day (ft/d) (Payne and others, 2020). The median of the hydraulic-conductivity values is $5.7 \mathrm{ft} / \mathrm{d}$ with most (70 percent) of the values between 1.00 and $9.99 \mathrm{ft} / \mathrm{d}$; values within the range of 1.00-9.99 $\mathrm{ft} / \mathrm{d}$ are mostly concentrated in Terry County. The largest areas with high hydraulic-conductivity values are west of Brownfield, Tex., in Terry County and southeast of Plains, Tex., in Yoakum County (fig. 24A). The lowest hydraulicconductivity values are in Terry County, south of Brownfield, Tex., near the border with Gaines County. A large area of low hydraulic conductivity (1.00 to $9.99 \mathrm{ft} / \mathrm{d}$ ) stretches from northern Terry County to Seminole, Tex.

The estimated specific yield values of the Ogallala aquifer range from 0.03 to 0.13 (unitless) with the specific yield variability ranging from 0.03 to 0.15 (Payne and others, 2020). The median of the specific yield values is 0.09 with most (59 percent) of the specific yield values between 0.09 and 0.12 . About one-half the specific yield variability values are greater than 0.10 . The highest specific yield values are in Terry County, west and southeast of Brownfield, Tex. (fig. 25A). The lowest specific yield values are in Gaines County, westnorthwest of Seminole, Tex., contained within an area of relatively low specific yields stretching from eastern Gaines County northeast towards the border of Gaines County with both Terry and Yoakum Counties. Generally, specific yield variability is relatively high in the northeastern and eastern parts of the study area and relatively low to the west and southwest. There is evidence of some correspondence between specific yield and specific yield variability values, in that lower specific yield variability is generally observed in areas where specific yield is higher.

\section{Edwards-Trinity (High Plains) Aquifer}

The hydraulic-conductivity values for the EdwardsTrinity (High Plains) aquifer range from about 0.03 to about $270 \mathrm{ft} / \mathrm{d}$ (Payne and others, 2020). The median of the hydraulic-conductivity values is $4.7 \mathrm{ft} / \mathrm{d}$ with most ( 65 percent) of the values between 1.00 and $9.99 \mathrm{ft} / \mathrm{d}$. The highest hydraulic-conductivity values are in southeastern Yoakum County near the border with Terry County, and southern Yoakum County near Denver City into northwest Gaines County (fig. 24B). There are also high hydraulic-conductivity values east of Brownfield, Tex., and in northeast of Seminole, Tex. The lowest hydraulic-conductivity values are in Terry County northwest of Brownfield, Tex., and in Yoakum County southeast of Plains, Tex.

The estimated specific yield values of the EdwardsTrinity (High Plains) aquifer range from 0.01 to 0.28 with the specific yield variability ranging from 0.05 to 0.15 (Payne and others, 2020). The median specific yield value for the Edwards-Trinity (High Plains) aquifer within the study area is 0.07 , and most ( 56 percent) of the specific yield values are between 0.05 and 0.08 . Almost all the study area (95 percent) has specific yield variability values greater than 0.10 and a median value of 0.15 . The highest specific yield values are in the north-central part of Yoakum County (fig. 25B). The lowest specific yield values are in eastern Gaines and Yoakum Counties and around Rich Lake in Terry County. The specific yield variability values are relatively high throughout the entire study area except in central Gaines County near borehole NMR data collection wells. This lower specific yield variability near the borehole NMR-logged wells is on account of the higher accuracy of the borehole NMR method relative to the regression method used to process the TDEM inverse modeling results.

\section{Dockum Aquifer}

There were substantially fewer hydraulic-conductivity values computed for wells completed only in the Dockum aquifer (27 wells) compared to wells completed only in the Ogallala (380 wells) or Edwards-Trinity (High Plains) (74 wells) aquifers. The available data were used to provide generalized insights regarding hydraulic properties of the aquifer. The hydraulic-conductivity values of the Dockum aquifer range from about 0.25 to about $240 \mathrm{ft} / \mathrm{d}$ (Payne and others, 2020). Most (52 percent) of the hydraulic-conductivity values are between 1.00 and $9.99 \mathrm{ft} / \mathrm{d}$ with a median value of $2.8 \mathrm{ft} / \mathrm{d}$. The highest hydraulic-conductivity value was measured in Gaines County south of Cedar Lake (fig. 24C). The lowest hydraulic conductivity also was measured in Gaines County, in the southeast corner of the county. Other low hydraulicconductivity values were measured in the northeast corner of the study area around Brownfield, Tex. 

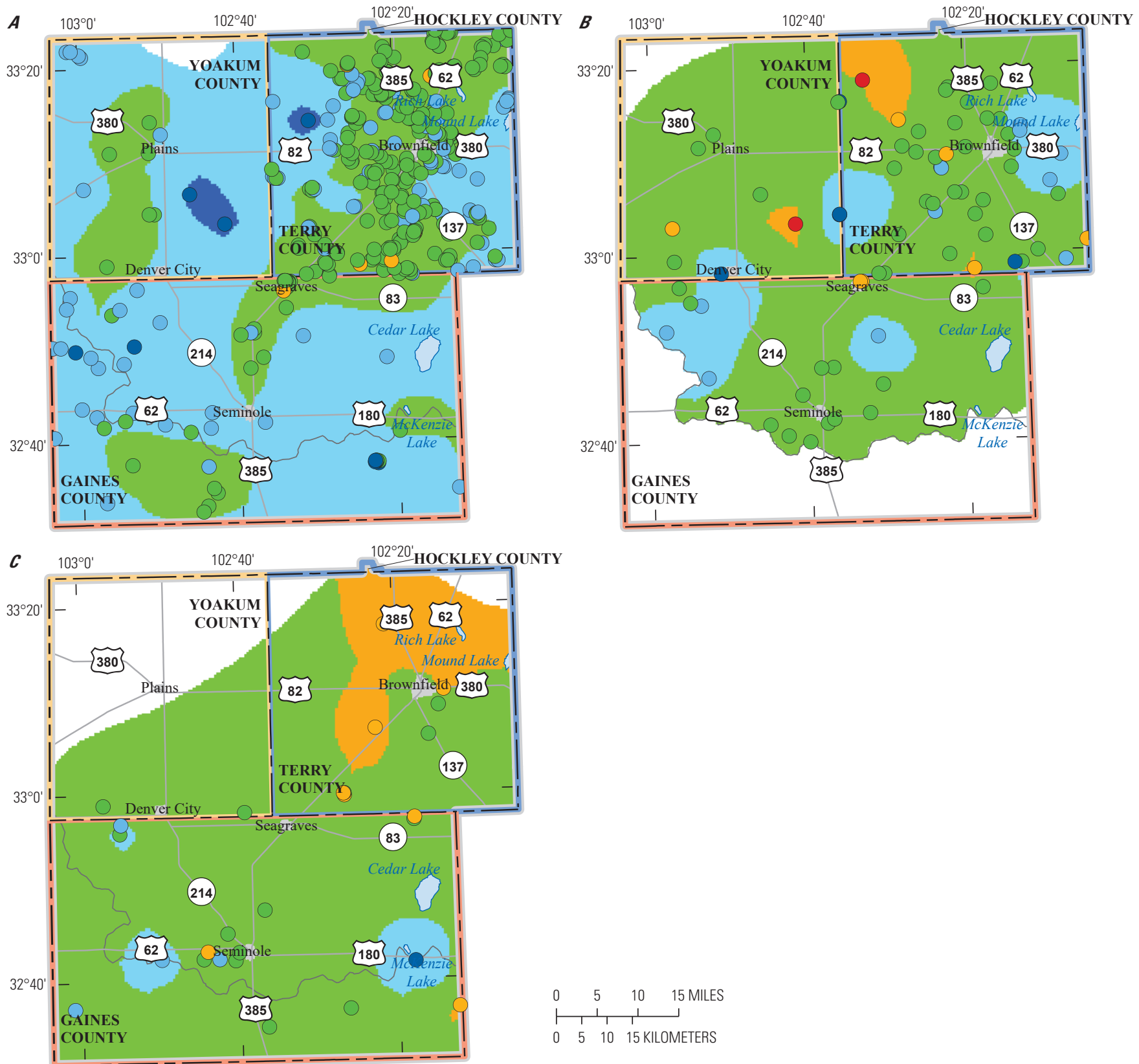

Base modified from U.S. Geological Survey 1:250,000-scale to 1:2,000,000-scale digital data, Universal Transverse Mercator projection, zone 13

North American Datum of 1983

\section{EXPLANATION}

\begin{tabular}{l}
$\begin{array}{l}\text { Estimated hydraulic conductivity, } \\
\text { in feet per day }\end{array}$ \\
\begin{tabular}{|l|l}
\hline & 0.100 to 0.999 \\
& 1.00 to 9.99 \\
& 10.0 to 99.9 \\
$\geq$ & 100
\end{tabular} \\
\hline
\end{tabular}

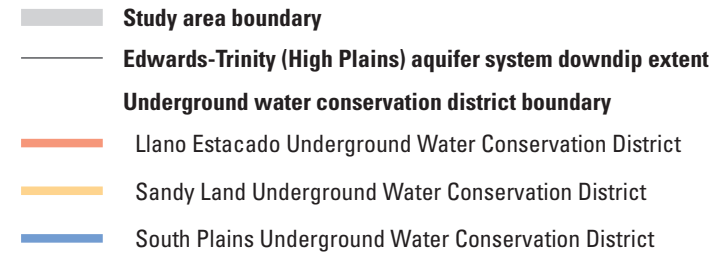
Hydraulic conductivity from well, in feet per day (Payne and others, 2020)
$<0.100$
0.100 to 0.999
1.00 to 9.99
- 10.0 to 99.9

Figure 24. Hydraulic-conductivity values computed from historical aquifer test, borehole electromagnetic flowmeter, and borehole nuclear magnetic resonance data for $A$, the 0 gallala aquifer, $B$, the Edwards-Trinity (High Plains) aquifer system, and $C$, the Dockum aquifer in and near Gaines, Terry, and Yoakum Counties, Texas. 

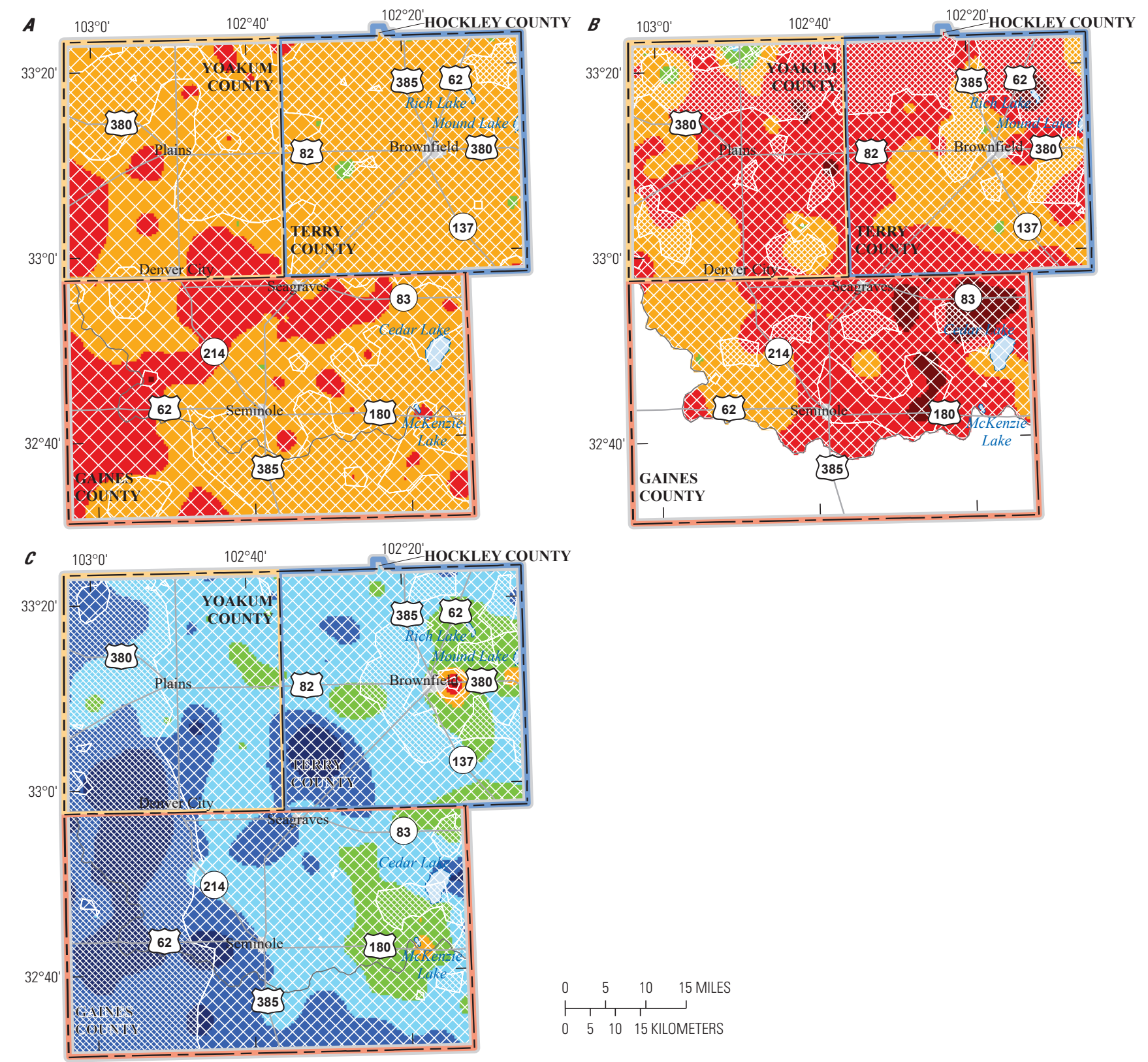

Base modified from U.S. Geological Survey 1:250,000-scale to 1:2,000,000-scale digital data, Universal Transverse Mercator projection, zone 13 North American Datum of 1983

\section{EXPLANATION}

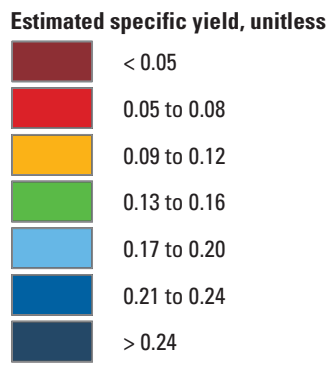

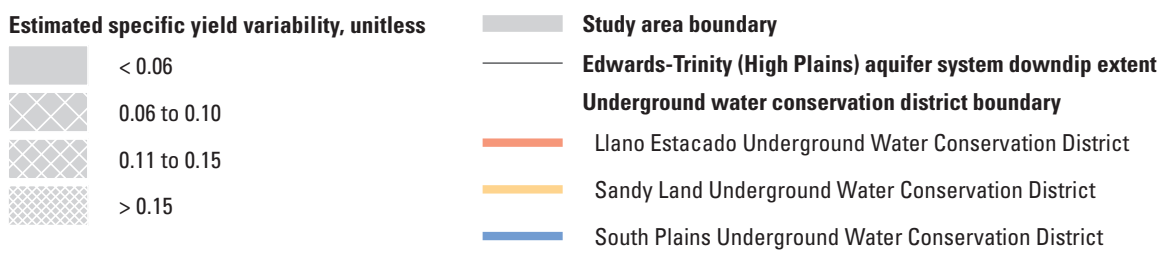

Figure 25. Estimated specific yield and specific yield variability values computed from borehole nuclear magnetic resonance and inverse modeling results of the time-domain electromagnetic data for $A$, the Ogallala aquifer, $B$, the Edwards-Trinity (High Plains) aquifer system, and $C$, the Dockum aquifer in and near Gaines, Terry, and Yoakum Counties, Texas. 
The estimated specific yield values for the Dockum aquifer range from 0.03 to 0.44 with the specific yield variability ranging from 0.06 to 0.15 (Payne and others, 2020). Most (67 percent) of the specific yield values are between 0.17 and 0.24 , and most of those values (37 percent of total) are between 0.17 and 0.20 . The median specific yield value for the Dockum aquifer is 0.19 . Similar to the specific yield variability values in the Edwards-Trinity (High Plains) aquifer, almost all of the study area (99 percent) has specific yield variability values greater than 0.10 with about one-third of the total values ( 34 percent) being greater than 0.15 . The median specific yield variability is 0.15 . The highest specific yield values are in the western part of the study area (northwest corner of Gaines County), whereas the lowest specific yield values are in the eastern part of the study area (east of Brownfield and east of Seminole) (fig. 25C). In general, the specific yield values decrease from west to east. The specific yield variability values are relatively high throughout the entire study area except near Brownfield, Tex., where borehole NMR data were collected. The high specific yield variability is expected in the Dockum aquifer because of the lower measured formation factors in the aquifer as a result of more clays causing a low bulk resistivity compared to the fluid resistivity.

\section{Conceptual Model}

A regional conceptual model was built by combining the results from the hydrogeologic framework, geochemistry, groundwater-flow system, and aquifer hydraulic properties analyses. In conjunction with the analysis of the hydrogeologic framework for each of the geologic units, a combined analysis was done for the Trinity and Fredericksburg Groups and Ogallala Formation (units that constitute the Ogallala and Edwards-Trinity (High Plains) aquifers that contain most of the groundwater used in the study area). The combined thickness of the Trinity and Fredericksburg Groups and Ogallala Formation is generally greatest in the north-central part of the study area and thinnest in the southeastern part of the study area (fig. 26). In Gaines and Terry Counties, the thickness of the combined Trinity and Fredericksburg Groups and Ogallala Formation generally decreases from the northwest corners of the counties to the southeast corners, whereas in Yoakum County, the combined thickness decreases from the northeast corner to the southwest corner of the county.

The groundwater geochemical results were evaluated further to spatially identify groups of similar groundwater samples. Groundwater samples were grouped on the basis of similarities found in the physicochemical properties, major ions, trace elements, nutrients, organic compounds, and selected stable isotopes and age tracers. This grouping of the groundwater is done to provide an overall summary of the geochemical results as it pertains to the study area. Three groundwater groups were identified in the study area as shown in table 5 (fig. 27).
The first groundwater group (Group 1) contains most (61 percent) of the groundwater wells sampled with all but one well in the northern half of the study area (fig. 27). The water in Group 1 is considered modern as shown by the tritium and carbon-14 concentrations and confirmed with high concentrations of nitrate plus nitrite and frequent detections of organic compounds (table 5). This group has the lowest strontium stable isotope ratios within the study area, which also indicates recent recharge because the groundwater has not had much time for isotopic exchange associated with water-rock interaction. Groundwater wells in Group 1 are primarily screened in either the Ogallala aquifer or Edwards-Trinity (High Plains) aquifer; only one well is screened in the Dockum aquifer (fig. 27). Recent recharge, affected by land-use activities, may explain the younger age, higher concentrations of nitrate plus nitrite, and more frequent detections of organic compounds for wells in Group 1.

Groundwater wells in the Group 2 are typically in the southwestern and northwestern parts of the study area (fig. 27). The groundwater in Group 2 is some of the oldest groundwater, as shown by the tritium and carbon-14 concentrations, and has the lowest DS concentrations in the study area (table 5). The relatively old age of the groundwater in Group 2 is supported by high strontium stable isotope ratios, which are indicative of an extended period of isotopic exchange associated with water-rock interactions. The hydrogen and oxygen stable isotope ratios in conjunction with tritium and carbon-14 concentrations indicate that the groundwater in Group 2 may have recharged during the Pleistocene period. Samples collected from 3 of the 5 wells completed in the Dockum aquifer have characteristics of groundwater in Group 2 (fig. 27).

The last group (Group 3) is likely a mixture of groundwater from Group 1 or Group 2 (or both) with a third, highly mineralized groundwater. The groundwater in Group 3 has the highest DS concentrations in the study area and has some geochemical characteristics similar to those in Group 1 and Group 2 (table 5). Some of the samples in Group 3 have similar characteristics to the groundwater in Group 2, including some of the oldest groundwater in the study area, as indicated by tritium and carbon- 14 concentrations, in addition to the highest calcium concentrations. Some of the samples in Group 3 are more similar to the groundwater in Group 1, having some of the highest nutrient concentrations in the study area in addition to being more modern, as indicated by the tritium and carbon-14 concentrations. Groundwater from Group 3 is also the most highly mineralized groundwater in the study area and typically is present near the southwest corner of Yoakum County and northwest corner of Gaines County, near Brownfield, Tex., in Terry County, and near Cedar Lake in Gaines County (fig. 27). The highly mineralized groundwater is from an unknown source but is interpreted to be from a deep saline source, as indicated by the sample at site 25644 , which has the highest DS concentration in the study area and the deepest screened interval at greater than 1,800 feet below land surface (Payne and others, 2020). Additional information is needed to confirm that this highly mineralized groundwater is from a deep source. 


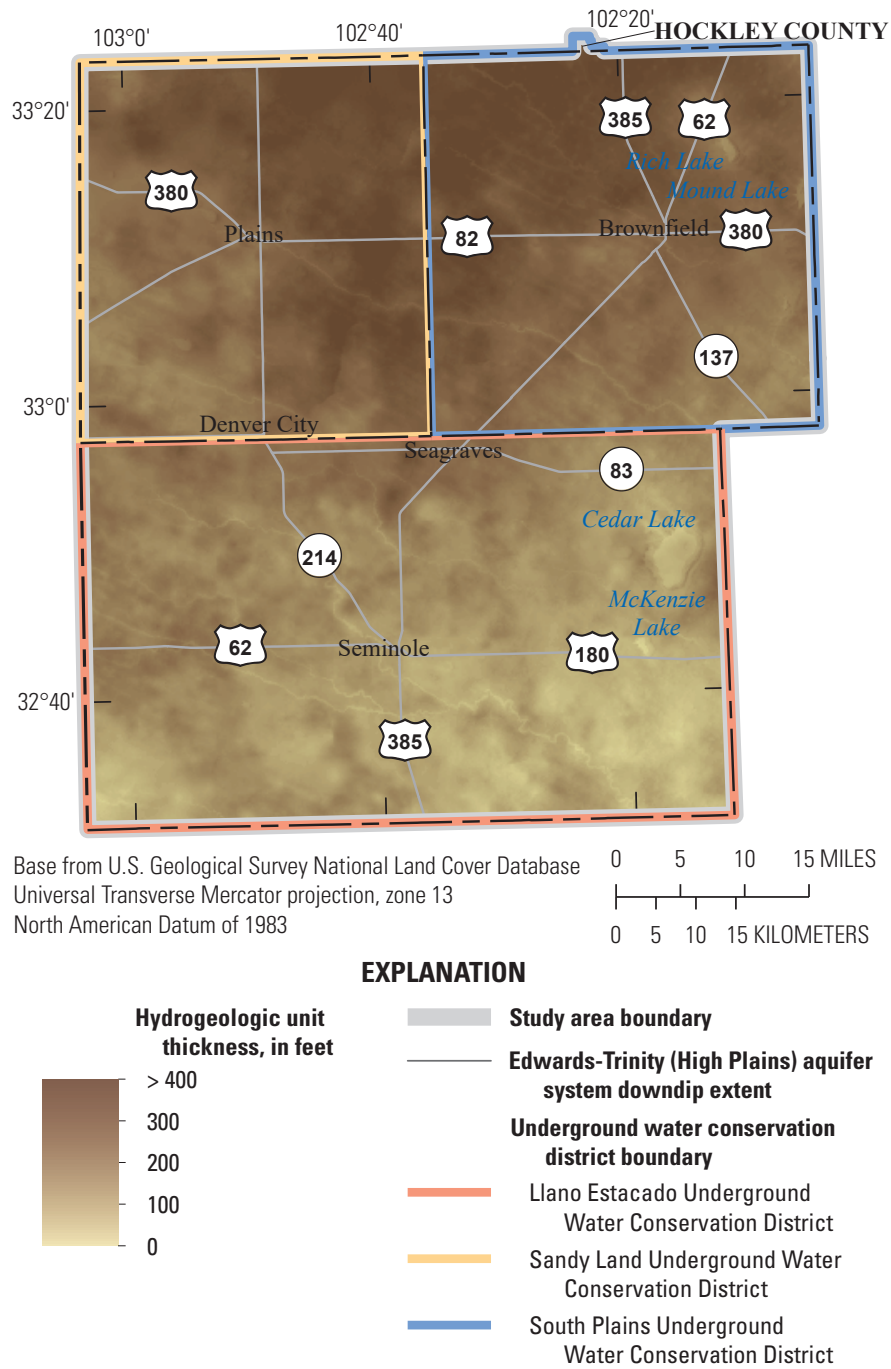

Figure 26. Combined hydrogeologic unit thickness of the Trinity and Fredericksburg Groups and Ogallala Formation in and near Gaines, Terry, and Yoakum Counties, Texas.

The results from the groundwater-flow system analysis were used to further assess the paleochannel analysis. The results of the paleochannel analysis from the trendremoval grids and hydrology toolset analysis (fig. 7) and the groundwater-flow paths determined from the potentiometric maps (fig. 19) exhibit similar results for groundwater-flow directions, especially for the Ogallala aquifer, for which more groundwater-level data were available (fig. 7C; fig. 19A). Results of a comparison of the two methods indicate that the groundwater flows preferentially through low-altitude areas of each aquifer, which correspond to the paleochannels. The groundwater-flow paths in the Ogallala aquifer tend to closely approximate the mapped paleochannels. The tendency for groundwater-flow paths and paleochannels to correspond indicates that within the study area, the groundwater flows preferentially along the paleochannels, especially within the Ogallala aquifer where dewatering of the aquifer results in a greater influence of the base structure on the flow of groundwater. There are some localized areas where the mapped paleochannels are different from the groundwater-flow paths in the Ogallala aquifer. The paleochannel analysis identified a few channels oriented towards the east that did not align with groundwater-flow paths, including some channels that cross the border between Yoakum and Terry Counties between Plains and Brownfield, Tex., and other channels that are northwest of, and east of, Seminole, Tex. (fig. 7C; fig. 19A). Instead, the groundwater-flow paths generally continued southeast in most of these locations, which is consistent with the general groundwater flow of the study area. Because of the lack of groundwater-level data for the Edwards-Trinity (High Plains) aquifer, the groundwater-flow path results (fig. 19B) are not detailed enough to compare to the paleochannel analysis results (fig. $7 A$ ), but the groundwater-flow paths did have the same general direction as the paleochannels found at the 


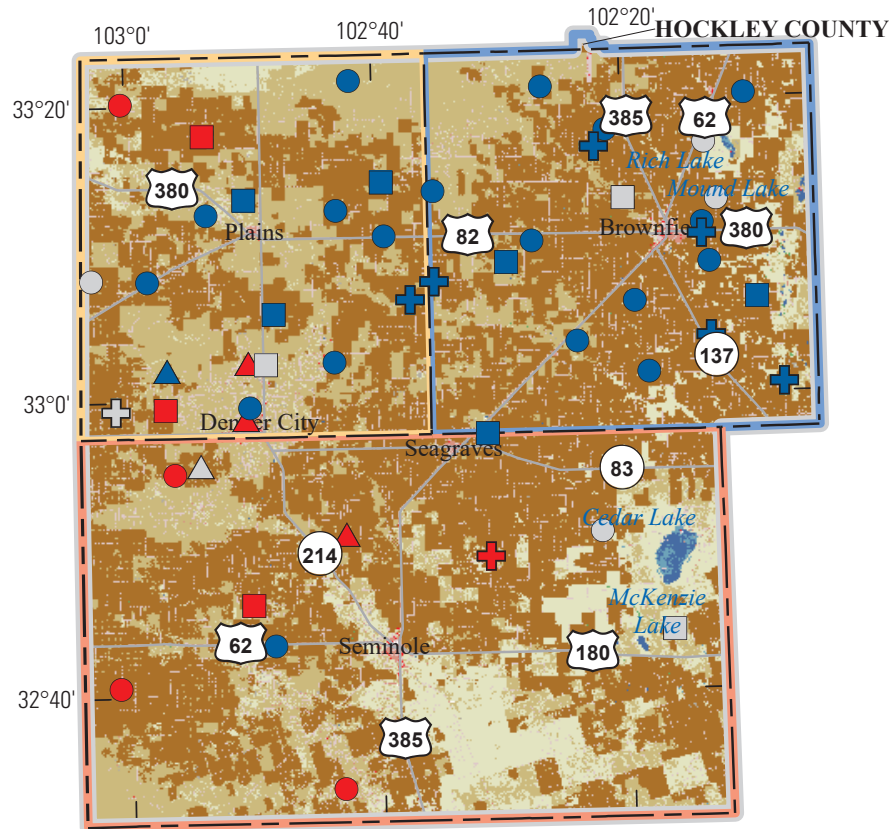

Base from U.S. Geological Survey National I and Cover Database $0 \quad 5 \quad 10 \quad 15$ MULES Universal Transverse Mercator projection, zone 13

North American Datum of 1983

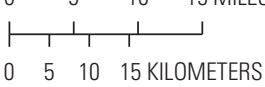

\section{EXPLANATION}

Land-cover category (Homer and others, 2015

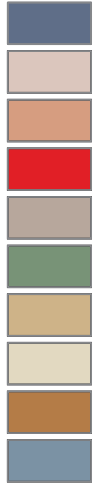

Open water

Developed, open space

Developed, low intensity

Developed, medium intensity

Barren land (rock/sand/clay)

Deciduous forest

Shrub/scrub

Grassland/herbaceous

Cultivated crops

Emergent herbaceous wetland

Study area boundary

Underground water conservation district boundary
Sample from well, by groundwater group (table 5)Symbol color represents groundwater group

Group 1

Group 2

Group 3

Sample from well, by aquifer (Payne and others, 2020)Symbol shape represents aquifer in which well was completed

Completed in the High Plains aquifer system (Ogallala aquifer)

Completed in the Edwards-Trinity (High Plains) aquifer system

$\triangle$ Completed in the Dockum aquifer

گ Completed in a combination of aquifers

\footnotetext{
Llano Estacado Underground Water Conservation District

Sandy Land Underground Water Conservation District South Plains Underground Water Conservation District
}

Figure 27. Groundwater groups for the water-quality samples collected in Gaines, Terry, and Yoakum Counties, Texas, 2014 and 2016. 
Table 5. Description of groundwater groups and median water-quality results for groundwater groups from water-quality samples collected in Gaines, Terry, and Yoakum Counties, 2014 and 2016.

$\left[\mathrm{mg} / \mathrm{L}\right.$, milligram per liter; $\mu \mathrm{g} / \mathrm{L}$, microgram per liter; $\delta \mathrm{D}$, delta deuterium; $\delta^{18} \mathrm{O}$, delta oxygen-18; ${ }^{87} \mathrm{Sr} / 86 \mathrm{Sr}$, strontium-87 per strontium-86; $\mathrm{pCi} / \mathrm{L}$, picocurie per liter]

\begin{tabular}{|c|c|c|c|}
\hline & \multicolumn{3}{|c|}{ Description of groups } \\
\hline Groundwater group: & Group 1 & Group 2 & Group 3 \\
\hline $\begin{array}{l}\text { Site identifier for wells (table 2) within groundwater } \\
\text { group }\end{array}$ & $\begin{array}{c}04518,04809,05380, \\
06260,07706, \\
08956,09493, \\
10676,10748, \\
11642,11771, \\
12504,14388, \\
18745,18790, \\
19639,20759, \\
20903,21524, \\
23705,24005, \\
24915,25865, \\
25883,27256, \\
27272,27287, \\
27488,27811, \\
28275,28367\end{array}$ & $\begin{array}{c}09503,09781,10061 \\
10509,10639 \\
20215,21325 \\
25208,25317 \\
26701,27727\end{array}$ & $\begin{array}{c}01500,03060,08389 \\
10523,12514 \\
15747,25644 \\
26458,27974\end{array}$ \\
\hline $\begin{array}{l}\text { Number of samples from wells completed in the High } \\
\text { Plains aquifer system (Ogallala aquifer) }\end{array}$ & 18 & 4 & 4 \\
\hline $\begin{array}{l}\text { Number of samples from wells completed in the Edwards- } \\
\text { Trinity (High Plains) aquifer system }\end{array}$ & 6 & 3 & 3 \\
\hline $\begin{array}{l}\text { Number of samples from wells completed in the Dockum } \\
\text { aquifer }\end{array}$ & 1 & 3 & 1 \\
\hline $\begin{array}{l}\text { Number of samples from wells completed in a combina- } \\
\text { tion of aquifers }\end{array}$ & 6 & 1 & 1 \\
\hline
\end{tabular}
tion of aquifers

Median results for water-quality constituents

Dissolved solids dried at 180 degrees Celsius, water, filtered $(\mathrm{mg} / \mathrm{L})$

Major ions

Bicarbonate, water, filtered, inflection-point titration method, field $(\mathrm{mg} / \mathrm{L})$

Calcium, water, filtered (mg/L)

Chloride, water, filtered $(\mathrm{mg} / \mathrm{L})$

Fluoride, water, filtered (mg/L)

Magnesium, water, filtered (mg/L)

Potassium, water, filtered (mg/L)

Sodium, water, filtered $(\mathrm{mg} / \mathrm{L})$

Sulfate, water, filtered $(\mathrm{mg} / \mathrm{L})$

Nitrate plus nitrite, water, filtered $(\mathrm{mg} / \mathrm{L}$ as nitrogen) [number of non-detects]

Deethylatrazine, water, filtered, recoverable $(\mu \mathrm{g} / \mathrm{L})$

[number of non-detects]

Metolachlor, water, filtered, recoverable $(\mu \mathrm{g} / \mathrm{L})$ [number of non-detects]

$\delta \mathbf{1 8} O$, water, unfiltered (per mil)

$\delta \mathrm{D}$, water, unfiltered (per mil)

${ }^{87} \mathrm{Sr} /{ }^{86} \mathrm{Sr}$, water, unfiltered

Tritium, water, unfiltered (pCi/L)

Carbon-14, water, filtered (percent modern)
268

$\begin{array}{ccc}72.6 & 100 & 297 \\ 152 & 198 & 73.0 \\ 4.35 & 2.82 & 322 \\ 88.5 & 55.2 & 3.47 \\ 12.2 & 4.35 & 55.3 \\ 108 & 83.5 & 7.15 \\ 284 & 125 & 265 \\ 8.02[0] & 4.66[0] & 426 \\ & & 10.5[1]\end{array}$

E0.006 [23] $\quad$ E0.008 [9] $\quad$ E0.021 [7]

$0.006[18] \quad 0.006[10] \quad 0.004[7]$

$\begin{array}{lll}-5.96 & -6.14 & -5.94\end{array}$

$\begin{array}{lll}-41.2 & -43.1 & -40.3\end{array}$

$\begin{array}{lll}0.70859 & 0.70863 & 0.70860\end{array}$

$\begin{array}{lll}3.50 & 1.34 & 3.80\end{array}$

$\begin{array}{lll}74.57 & 44.36 & 67.60\end{array}$


base of the Trinity Group. The paleochannel analysis was not performed for the Dockum Group, so a comparison between the paleochannels of the Dockum Group and the groundwaterflow paths within the Dockum aquifer was not possible.

Saturated thickness for the Ogallala and the combined Ogallala and Edwards-Trinity (High Plains) aquifers can be estimated by computing the difference between the altitude of the water table and the altitude of the base of the aquifer at a given location (fig. 28). The saturated thickness of the Ogallala aquifer can vary substantially in a relatively small area in response to substantial spatial variations in the base of the Ogallala Formation (fig. 28A). The Ogallala aquifer is unsaturated in localized areas in the study area; unsaturated areas are generally present near the southern extent of the Edwards-Trinity (High Plains) aquifer, with the largest unsaturated area west of Seminole, Tex. The saturated thickness of the Ogallala aquifer is thickest (more than 125 feet) southeast of Seminole and west of Brownfield, Tex., near the border between Terry and Yoakum Counties. Although the saturated thickness varies locally, regionally thinner sections in the Ogallala aquifer extend from north-central Terry County to the southeast and from the southwest corner of Yoakum County to south-central Gaines County. Regionally thicker sections of the saturated part of the Ogallala aquifer are in the northcentral part of the study area from northeast Yoakum County to the southwest corner of Terry County and in the southeast corner of Gaines County.

The saturated thickness of the combined Ogallala and Edwards-Trinity (High Plains) aquifers are laterally persistent compared to the Ogallala aquifer alone (fig. 28B). This is a result of the larger aquifer thickness incorporated into the overall saturated thickness of the combined aquifer system. The saturated thickness of the combined Ogallala and Edwards-Trinity (High Plains) aquifers ranges from less than 10 feet along the far southern edge of the study area to more than 350 feet north and east of Brownfield, Tex., and along the border between Terry and Yoakum Counties. In general, the saturated part of the combined Ogallala and Edwards-Trinity (High Plains) aquifers is thinnest in the south and southwest of the study area where the thickness of the Fredericksburg and Trinity Groups are the thinnest or not present.

The volume of water stored within the saturated thickness depends on many factors, including the aquifer extent, specific yield, and saturated thickness of the hydrogeologic unit (Gutentag and others, 1984). Using the estimated saturated thickness and the estimated specific yield grids, the water volumes of the Ogallala, Edwards-Trinity (High Plains), and the combined Ogallala and Edwards-Trinity (High Plains) aquifers were estimated (table 6). The available water in the Edwards-Trinity (High Plains) aquifer (16.6 million acre-feet) is almost double the available water in the Ogallala aquifer (8.8 million acre-feet) in the study area. The semiconfined nature of the Edwards-Trinity (High Plains) aquifer may result in this value being an underestimate because more water may be retained in the aquifer as a result of increased pressure in the aquifer from confining conditions. Although the Edwards-Trinity (High Plains) aquifer contains more available groundwater than the Ogallala aquifer, retrieving the groundwater from the Edwards-Trinity (High Plains) aquifer is more difficult because of the relatively low hydraulic conductivity and specific yield values compared to the Ogallala aquifer. Overall, the available water within the combined Ogallala and Edwards-Trinity (High Plains) aquifers is about 6.6, 10.2, and 8.6 million acre-feet for Gaines, Terry, and Yoakum Counties, respectively.

Because of the high variability associated with the specific yield values (the specific yield range is determined from the specific yield and the specific yield variability values), the resulting computed values for available groundwater in storage are highly variable as well. Within the Ogallala and Edwards-Trinity (High Plains) aquifers, the minimum volume of groundwater in storage (computed using the specific yield minus the specific yield variability) is 0 million acre-feet (table 6). The maximum volume of storage (computed using the specific yield plus the specific yield variability) for the Ogallala aquifer is about 19.2 million acre-feet for the study area and about 8.6, 5.6, and 5.0 million acre-feet for Gaines, Terry, and Yoakum Counties, respectively. These maximum values match closely to the total estimated recoverable storage volumes computed by Kohlrenken and others (2013) (table 6). The maximum storage volume for the Edwards-Trinity (High Plains) aquifer is about 50.4 million acre-feet for the study area and about 8.1, 23.6, and 18.7 million acre-feet for Gaines, Terry, and Yoakum Counties, respectively (table 6). These maximum storage values are much greater than those reported by Kohlrenken and others (2013); the estimated average storage values for the Edwards-Trinity (High Plains) aquifer are relatively close to those in Kohlrenken and others (2013). Overall, the maximum estimated storage of the combined Ogallala and Edwards-Trinity (High Plains) aquifers is 69.6 million acre-feet with about 16.7, 29.2, and 23.7 million acre-feet of groundwater storage in Gaines, Terry, and Yoakum Counties, respectively (table 6). The high specific yield variability can be attributed to many factors, such as the bulk measurement of resistivity from TDEM soundings, the fairly low goodness-of-fit for the regression models between the total porosity and formation factor (from bulk resistivity and estimated fluid resistivity), and the estimated fluid resistivity across the study area. The high specific yield variability could be reduced substantially with additional NMR data throughout the study area. Tortuosity and cementation data (from Archie's Law) could also help reduce the specific yield variability by optimizing the regression model between total porosity and formation factor. Additional specific conductance data throughout the study area could provide better fluid resistivity values to compute formation factors to use in the regression models. 


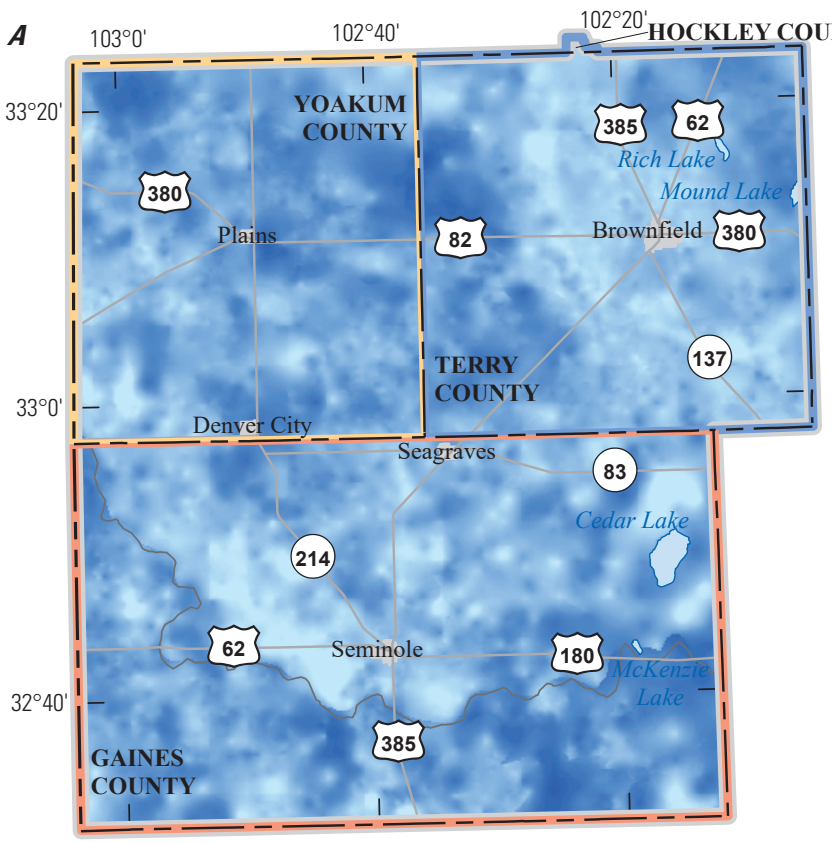

Base modified from U.S. Geological Survey 1:250,000-scale to 1:2,000,000-scale digital data Universal Transverse Mercator projection, zone 13 North American Datum of 1983

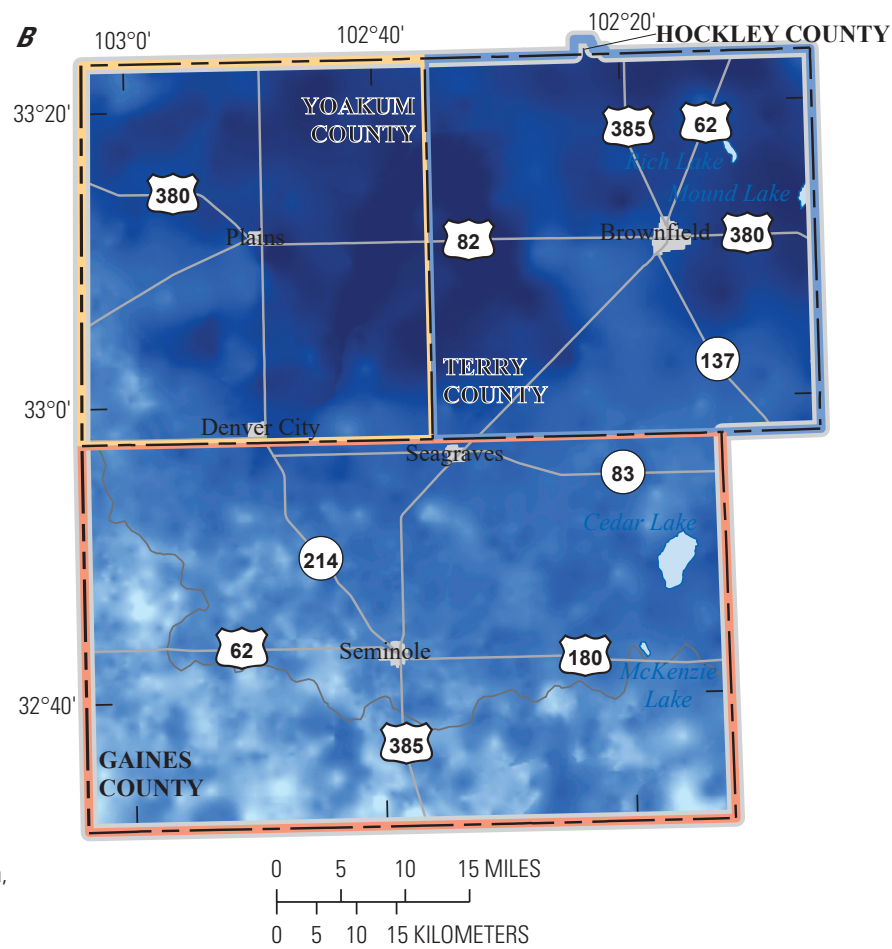

\section{EXPLANATION}

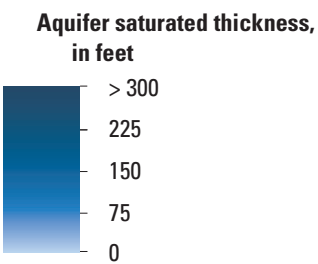

\section{Study area boundary}

Edwards-Trinity (High Plains) aquifer system downdip extent Underground water conservation district boundary

Llano Estacado Underground Water Conservation District

Sandy Land Underground Water Conservation District

South Plains Underground Water Conservation District

Figure 28. Saturated thickness of $A$, the Ogallala aquifer and $B$, the combined Ogallala aquifer and the Edwards-Trinity (High Plains) aquifer system in and near Gaines, Terry, and Yoakum Counties, Texas 
Table 6. Estimated groundwater storage volumes (minimum, maximum, and average) computed from the estimated saturated thickness and estimated specific yield and specific yield variability values computed from borehole nuclear magnetic resonance and inverse modeling results of the time-domain electromagnetic data for the High Plains aquifer system (Ogallala aquifer), Edwards-Trinity (High Plains) aquifer system, and the combined Ogallala aquifer and Edwards-Trinity (High Plains) aquifer systems in and near Gaines, Terry, and Yoakum Counties, Texas.

[LEUWCD, Llano Estacado Underground Water Conservation District; SPUWCD, South Plains Underground Water Conservation District; SLUWCD, Sandy Land Underground Water Conservation District]

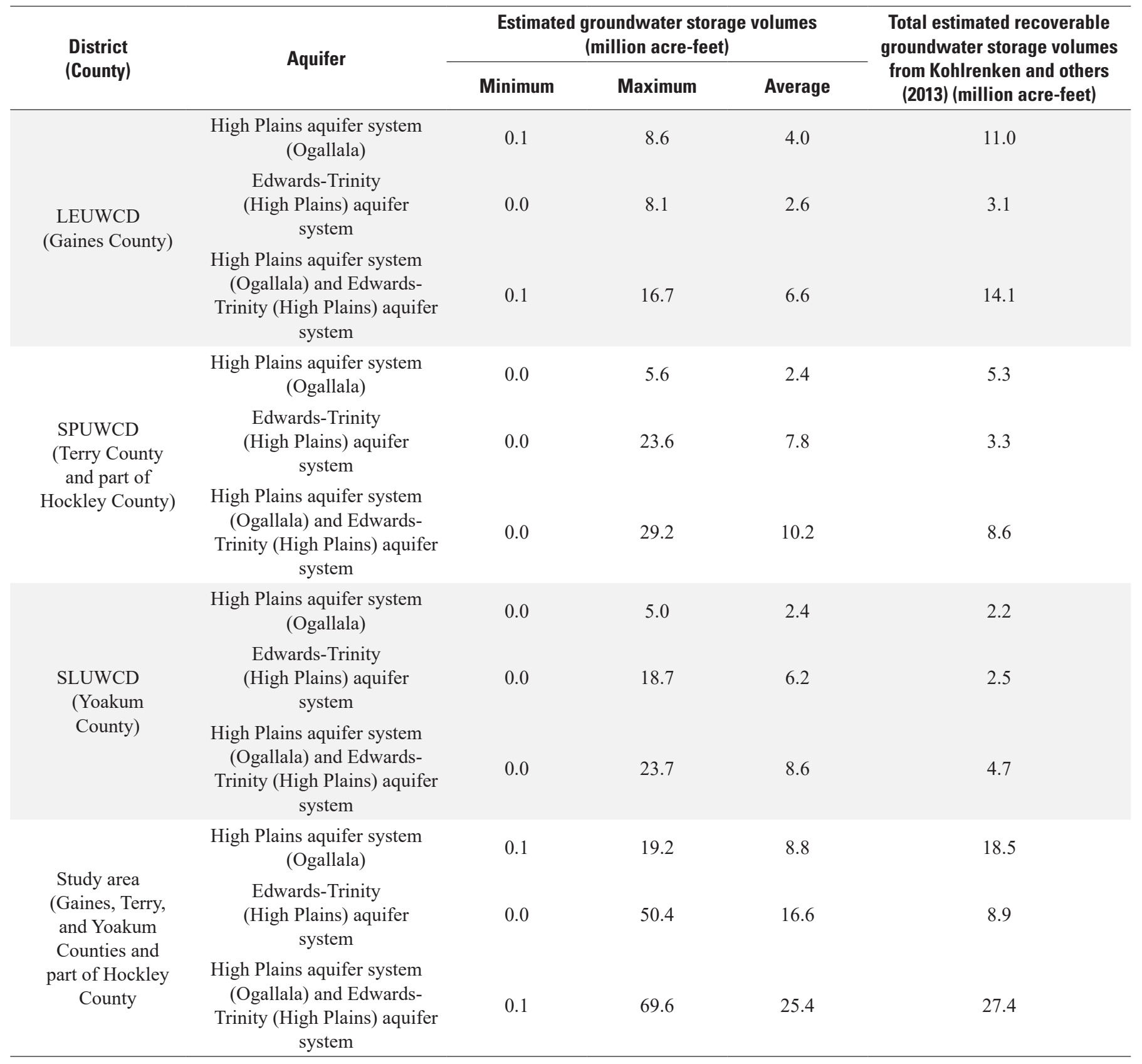




\section{Summary}

Llano Estacado Underground Water Conservation District (LEUWCD), Sandy Land Underground Water Conservation District (SLUWCD), and South Plains Underground Water Conservation District (SPUWCD) (hereinafter referred to collectively as the "UWCDs") manage groundwater resources in a part of west Texas near the Texas-New Mexico State line. The High Plains aquifer system (hereinafter referred to as the "Ogallala aquifer"), that in Texas is contained within the Ogallala Formation, is the shallowest aquifer in the study area and is the primary source of water for agriculture and municipal supply in the areas managed by the UWCDs. Groundwater withdrawals from deeper aquifers (primarily from the Edwards-Trinity (High Plains) aquifer system, hereinafter referred to as the "Edwards-Trinity [High Plains] aquifer," augmented by lesser amounts from the Dockum aquifer) provide additional water sources in the study area. The Edwards-Trinity (High Plains) aquifer is contained within the Trinity and Fredericksburg Groups. The Dockum aquifer, a relatively minor source of water in the study area, is contained in the Dockum Group which was evaluated as a single unit.

Groundwater levels have been documented to decline (more than 50 feet [ft]) in Texas since 1938 with declines occurring overall in the Ogallala aquifer soon after the beginning of substantial irrigation with groundwater from the aquifer (about 1950). The potential for continual declines of the groundwater in the Ogallala aquifer in the study area has raised concerns about the amount of available groundwater. Also of concern are the potential changes in water-quality resulting from dewatering and increased vertical groundwater movement between adjacent water-bearing units. Because the Ogallala aquifer and underlying aquifers are hydraulically connected in some locations, groundwater-level declines in the Ogallala aquifer and in the underlying Edwards-Trinity (High Plains) aquifer can result in changes in the water quality when mixed with the upward movement of deeper, relatively more saline groundwater. In 2014, the U.S. Geological Survey (USGS), in cooperation with the UWCDs, began a multiphase study to refine the understanding of the hydrogeologic framework, geochemistry, groundwater-flow system, and hydraulic properties to be included in the development of a regional conceptual model for the Ogallala, Edwards-Trinity (High Plains), and the Dockum aquifers.

The conceptual model helped in the understanding of the quantity and quality of the groundwater within the Ogallala, Edwards-Trinity (High Plains), and to a lesser extent the Dockum aquifers within the study area. The hydrogeologic framework was used to assess the vertical and lateral extents of hydrogeologic units, bed orientation, unit thickness, and location and orientation of paleochannels. The geochemistry helped to better understand general water quality and provide insight into groundwater-flow paths and recharge sources as well as mixing pathways. The groundwater-flow system analysis aided in evaluating the spatial groundwater-level-altitude changes and identifying regional groundwater-flow paths and gradients. The aquifer hydraulic properties, including hydraulic conductivity and specific yield, were estimated to better understand the ability of groundwater to move through the aquifer system and quantify the volume of available water in storage.

The analysis for the hydrogeologic framework consisted mostly of the compilation and review of available data; additional geophysical data were collected in selected areas to improve the spatial coverage across the study area and to reduce uncertainty regarding hydrogeologic unit extents. In general, the Trinity and Fredericksburg Groups and Ogallala Formation exhibit a slight regional dip (dip angle of about 0.14 degrees) to the southeast with dip directions becoming more to the south with each successively overlying unit $(105,110$, and 125 degrees for the bases of the Trinity and Fredericksburg Groups and Ogallala Formation, respectively). The highest altitudes for each of the groups are in the northwest corner of the study area, and the lowest altitudes for each group are in the southeastern to eastern parts.

Paleochannel orientation varied over geologic time as formations were deposited and eroded. Paleochannels eroded into the Dockum Group as represented by the bases of the Trinity Group and Ogallala Formation (where the Trinity Group is not present) generally have a west to east direction. Paleochannels eroded into the Trinity Group, as represented by the base of the Fredericksburg Group, generally have a west to east direction. Paleochannels eroded into the Dockum (where the Fredericksburg Group is not present) and Fredericksburg Groups, as represented collectively by the base of the Ogallala Formation, generally have a northwest to southeast direction. Deep paleochannels (trend-removal value less than $-25 \mathrm{ft}$ ) were found to be eroded into the Dockum Group, as represented by the base of the Trinity Group (north border of Terry County); eroded into the Trinity Group, as represented by the base of the Fredericksburg Group (north border of Terry County); and eroded into the Dockum (where the Fredericksburg Group is not present) and Fredericksburg Groups, as represented collectively by the base of the Ogallala Formation (southwest corner of the study area and near the northwest corner of Terry County). Moderately deep paleochannels (trend-removal value between -10 and $-25 \mathrm{ft}$ ) were found in the central part of the study area eroded into the Dockum, Trinity, and Fredericksburg Groups, which may provide possible pathway links (as shown by some of the stream paths from the hydrology toolset analysis) between deeper paleochannels.

Relative to the other geologic units assessed for this study (the Trinity and Fredericksburg Groups and Ogallala Formation), the Dockum Group was found to have a much greater average thickness (approximately 2,115 feet), with the thickest parts of the Dockum Group in the western part of the study area and thinnest in the eastern part of the study area. Within the study area, the thicknesses of the Trinity and Fredericksburg Groups and Ogallala Formation vary locally, depending on the presence of erosional features such as paleochannels. In general, the Trinity and Fredericksburg 
Groups thin to the south and are not present in the southern part of Gaines County, whereas the Ogallala Formation becomes thinner from west to east. The combined thickness of the Trinity and Fredericksburg Groups and Ogallala Formation (units that comprise the Ogallala and Edwards-Trinity [High Plains] aquifers that contain most of the groundwater used in the study area) is generally greatest in the north-central part of the study area and thinnest in the southeastern part of the study area.

Water-quality samples were collected from 51 wells throughout the study area to better understand general water quality and to provide insight into groundwater-flow paths and recharge areas. Groundwater samples were spatially grouped on the basis of similarities found in the physicochemical properties, major ions, trace elements, nutrients, organic compounds, and selected stable isotopes and age tracers. Three groundwater groups were identified in the study area. The first groundwater group (Group 1), represented mostly by groundwater from the Ogallala and Edwards-Trinity (High Plains) aquifers in the northern half of the study area, contains most (61 percent) of the groundwater wells sampled, and the groundwater is considered to be recent recharge, affected by land-use activities, as explained by the younger age, higher concentrations of nitrate plus nitrite, and more frequent detections of organic compounds. Groundwater wells in the second groundwater group (Group 2) are typically in the southwestern and northwestern parts of the study area, and the groundwater is considered to have been recharged during the Pleistocene period, as explained by the relatively old age of the groundwater, high strontium stable isotope ratios, and hydrogen and oxygen stable isotope ratios. The last group (Group 3) is likely a mixture of groundwater from Group 1 or Group 2 (or both) with a third, highly mineralized groundwater as explained by having the highest dissolved-solids concentrations in the study area and having some similarities to geochemical characteristics of groundwater from Groups 1 and 2. The highly mineralized groundwater is from an unknown source but is interpreted to be from a deeper saline source; in order to confirm this interpretation additional information is needed.

A groundwater-flow system analysis was done to understand the flow of groundwater throughout the aquifer system. Groundwater-level altitudes for the Ogallala, Edwards-Trinity (High Plains), and Dockum aquifers are generally higher in the northwestern part of the study area and lower in the southeastern part of the study area. Groundwater generally flows in a northwest to southeast direction across the study area in each of the aquifers. The results from the groundwater-flow system analysis were used to further assess the paleochannel analysis. The groundwater-flow paths closely resemble the mapped paleochannels, indicating that within the study area, the groundwater flows preferentially along the paleochannels, especially within the Ogallala aquifer where dewatering of the aquifer results in a greater effect of the base structure on the flow of groundwater.
Saturated thickness for the Ogallala and the combined Ogallala and Edwards-Trinity (High Plains) aquifers was estimated by computing the difference between the altitude of the water table and the altitude of the base of the aquifer at a given location. The Ogallala aquifer is unsaturated in localized areas in the study area. Unsaturated areas are generally near the southern extent of the Edwards-Trinity (High Plains) aquifer, with the largest unsaturated area west of Seminole, Tex. The saturated thickness of the Ogallala aquifer is thickest (more than 125 feet) southeast of Seminole and west of Brownfield, Tex., near the border between Terry and Yoakum Counties. The saturated thickness of the combined Ogallala and Edwards-Trinity (High Plains) aquifers is laterally persistent compared to the Ogallala aquifer alone. The saturated thickness of the combined Ogallala and Edwards-Trinity (High Plains) aquifers ranges from less than 10 feet along the far southern edge of the study area to more than 350 feet north and east of Brownfield, Tex., and along the border between Terry and Yoakum Counties.

To estimate the hydraulic properties for the aquifer system, available historical data were compiled and supplemented with the collection of borehole and surface geophysical data. The hydraulic-conductivity values varied greatly within the study area (ranging from about 0.03 to about 350 feet per day), and often large variations were found in the same area. Terry County contained the highest and lowest hydraulic conductivity values for the Ogallala aquifer, while Yoakum County contained the highest and lowest hydraulic conductivity values for the Edwards-Trinity (High Plains) aquifers. The highest hydraulic-conductivity values for the Dockum aquifer were in Gaines Counties whereas the lowest hydraulic-conductivity values were in Terry County. The median hydraulic conductivity value in each aquifer decreased with depth $(5.7,4.7$, and 2.8 feet per day for the Ogallala, Edwards-Trinity [High Plains], and Dockum aquifers, respectively). Overall, the Ogallala aquifer has the highest hydraulic-conductivity values, whereas the Dockum aquifer has the lowest values in the study area. The estimated specific yield values within the study area ranged from 0.01 to 0.36 with the median value in each aquifer being $0.09,0.07$, and 0.19 for the Ogallala, EdwardsTrinity (High Plains), and Dockum aquifers, respectively. The specific yield variability ranged from 0.03 to 0.15 with more variability observed at deeper depths. The higher specific yield values are generally in the western parts of the study area except in the Ogallala aquifer where the higher specific yield values are in the east. The Ogallala aquifer has the lowest specific yield range and the least specific yield variability among the three aquifers, whereas the Dockum aquifer has the highest specific yield range and the greatest specific yield variability.

Using the estimated saturated thickness and the estimated specific yield grids, the water volumes of the Ogallala, Edwards-Trinity (High Plains), and the combined Ogallala and Edwards-Trinity (High Plains) aquifers were estimated. The available water in the Edwards-Trinity (High Plains) aquifer (16.6 million acre-feet) is almost double the available water in the Ogallala aquifer ( 8.8 million acre-feet) in the study area. 
Overall, the available water within the combined Ogallala and Edwards-Trinity (High Plains) aquifers is about 6.6, 10.2, and 8.6 million acre-feet for Gaines, Terry, and Yoakum Counties, respectively. Because of the high variability associated with the specific yield values, the resulting computed values for available groundwater in storage are highly variable as well. Within the Ogallala and Edwards-Trinity (High Plains) aquifers, the minimum volume of groundwater in storage is very near 0 million acre-feet. The maximum volume of storage for the Ogallala aquifer is about 19.2 million acre-feet for the study area and about 8.6, 5.6, and 5.0 million acrefeet for Gaines, Terry, and Yoakum Counties, respectively, whereas the maximum storage volume for the Edwards-Trinity (High Plains) aquifer is about 50.4 million acre-feet for the study area and about 8.1, 23.6, and 18.7 million acre-feet for Gaines, Terry, and Yoakum Counties, respectively. Overall, the maximum estimated storage of the combined Ogallala and Edwards-Trinity (High Plains) aquifers is 69.6 million acre-feet with about 16.7, 29.2, and 23.7 million acre-feet of groundwater storage in Gaines, Terry, and Yoakum Counties, respectively. The high specific yield variability could be reduced substantially with additional nuclear magnetic resonance, tortuosity and cementation, and specific conductance data throughout the study area.

\section{References Cited}

American Public Health Association, 1998, Standard methods for the examination of water and wastewater (20th ed.): Washington, D.C., American Public Health Association, American Water Works Association, and Water Environment Federation, p. 3-37-3-43.

American Society of Testing and Materials, 1999, Standard guide for selecting surface geophysical methods: American Society of Testing and Materials (ASTM)-D 6429-99, 11 p.

American Society of Testing and Materials, 2004, Standard guide for conducting borehole geophysical loggingMechanical caliper: American Society of Testing and Materials (ASTM)-D 6767-97, 6 p.

American Society of Testing and Materials, 2007, Standard guide for conducting borehole geophysical loggingElectromagnetic induction: American Society of Testing and Materials (ASTM)-D 6726-01, 8 p.

American Society of Testing and Materials, 2010, Standard guide for planning and conducting borehole geophysical logging: American Society of Testing and Materials (ASTM)-D 5753-05, 9 p.

Archie, G.E., 1952, Classification of carbonate reservoir rocks and petrophysical considerations: AAPG Bulletin, v. 36, no. 2, p. 218-298.
Arps, J.J., 1945, Analysis of decline curves: Transactions of AIME, v. 160 , p. 228-247.

Arps, J.J., 1956, Estimation of primary oil reserves: Transactions of AIME, v. 207, p. 182-191.

Ashworth, J.B., and Hopkins, J., 1995, Aquifers of Texas: Texas Water Development Board Report 345, 69 p.

Banner, J.L., 2004, Radiogenic isotopes-Systematics and applications to earth surface processes and chemical stratigraphy: Earth-Science Reviews, v. 65, no. 3-4, p. 141-194.

Banner, J.L., Musgrove, M., and Capo, R.C., 1994, Tracing groundwater evolution in a limestone aquifer using $\mathrm{Sr}$ isotopes-Effects of multiple sources of dissolved ions and mineral-solution reactions: Geology, v. 22, no. 8, p. $687-690$.

Bartos, T.T., and Ogle, K.M., 2002, Water quality and environmental isotopic analyses of ground-water samples collected from Wasatch and Fort Union Formations in areas of coalbed methane development-Implications to recharge and groundwater flow, eastern Powder River Basin, Wyoming: U.S. Geological Survey Water-Resources Investigations Report 02-4045, 96 p., accessed January 23, 2020, at https://doi.org/10.3133/wri024045.

Bear, J., 1979, Hydraulics of groundwater: New York, McGraw-Hill, 569 p.

Behroozmand, A.A., Keating, K., and Auken, E., 2015, A review of the principles and applications of the NMR technique for near-surface characterization: Surveys in Geophysics, v. 36, no. 1, p. 27-85, accessed January 23, 2020, at https://doi.org/10.1007/s10712-014-9304-0.

Bell, A.E., and Morrison, S., 1979, Analytical study of the Ogallala aquifer in Gaines County, Texas: Texas Department of Water Resources Report 227, 63 p.

Blandford, T.N., Blazer, D.J., Calhoun, K.C., Dutton, A.R., Naing, T., Reedy, R.C., and Scanlon, B.R., 2003, Groundwater availability of the southern Ogallala aquifer in Texas and New Mexico-Numerical simulations through 2050: Texas Water Development Board, 169 p. [Also available at https://www.twdb.texas.gov/groundwater/models/ gam/ogll_s/OGLL_S_Full_Report.pdf.]

Bradley, R.G., and Kalaswad, S., 2003, The groundwater resources of the Dockum aquifer in Texas: Texas Water Development Board Report 359, 81 p.

Brady, R., and Bush, A., 2018, Groundwater Conservation District annual water level measurement programs - Water elevation maps, Gaines, Terry \& Yoakum Counties: Llano Estacado Underground Water Conservation District, Sandy Land Underground Water Conservation District, and South Plains Underground Water Conservation District pamphlet. 
Brand, J.P., 1953, Cretaceous of Llano Estacado of Texas: The University of Texas at Austin, Bureau of Economic Geology Report of Investigations No. 20,67 p. [Also available at https://store.beg.utexas.edu/reports-of-investigations/986ri0020.html.]

Bumgarner, J.R., Stanton, G.P., Teeple, A.P., Thomas, J.V., Houston, N.A., Payne, J.D., and Musgrove, M.L., 2012, A conceptual model of the hydrogeologic framework, geochemistry, and groundwater-flow system of the EdwardsTrinity and related aquifers in the Pecos County region, Texas: U.S. Geological Survey Scientific Investigations Report 2012-5124 (revised July 10, 2012), 74 p. [Also available at https://doi.org/10.3133/sir20125124.]

Burke, W.H., Denison, R.E., Hetherington, E.A., Koepnick, R.B., Nelson, H.F., and Otto, J.B., 1982, Variation of seawater ${ }^{87} \mathrm{Sr} / 86 \mathrm{Sr}$ throughout Phanerozoic time: Geology, v. 10, no. 10 , p. 516-519.

Canadian Well Logging Society, 2020, LAS—Log ASCII Standard (LAS): Canadian Well Logging Society, accessed June 22, 2020, at https://www.cwls.org/products/ \#products-las.

Century Geophysical Corporation, 2020, Logging tools: Century Geophysical Corporation accessed January 23, 2020, at https://www.century-geo.com/multiparameter-probes.

Childress, C.J.O., Forman, W.T., Connor, B.F., and Maloney, T.J., 1999, New reporting procedures based on long-term method detection levels and some considerations for interpretations of water-quality data provided by the U.S. Geological Survey National Water Quality Laboratory: U.S. Geological Survey Open-File Report 99-193, 19 p., accessed December 18, 2019, at https://doi.org/10.3133/ofr9 9193.

Clark, B.R., Bumgarner, J.R., Houston, N.A., and Foster, A.L., 2014, Simulation of groundwater flow in the EdwardsTrinity and related aquifers in the Pecos County region, Texas (ver. 1.1, August 2014): U.S. Geological Survey Scientific Investigations Report 2013-5228, 56 p., accessed January 23, 2020, at https://doi.org/10.3133/sir20135228.

Clark, I.D., and Fritz, P., 1997, Environmental isotopes in hydrogeology: Boca Raton, Fla., Lewis Publishers, 328 p.

Constable, S.C., Parker, R.L., and Constable, C.G., 1987, Occam's inversion-A practical algorithm for generating smooth models from electromagnetic sounding data: Geophysics, v. 52, no. 3, p. 289-300.

Craig, H., 1961, Isotopic variations in meteoric waters: Science, v. 133 , no. 3465 , p. 1702-1703.
Crain, E.R., 2019, Crain's petrophysical handbook-Clay/ shale basics: E.R.Crain, accessed January 17, 2020, at https://www.spec2000.net/11-vshbasics.htm.

Cronin, J.G., 1969, Groundwater in the Ogallala Formation in the Southern High Plains of Texas and New Mexico: U.S. Geological Survey Hydrogeologic Investigations Atlas, v. HA-330, accessed January 23, 2020, at https://doi.org/ $10.3133 /$ ha330.

Cunningham, W.L., and Schalk, C.W., comps., 2011, Groundwater technical procedures of the U.S. Geological Survey: U.S. Geological Survey Techniques and Methods 1-A1, 151 p., accessed January 23, 2020, at https://doi.org/ $10.3133 / \mathrm{tm} 1 \mathrm{~A} 1$.

Day-Lewis, F.D., Johnson, C.D., Paillet, F.L., and Halford, K.J., 2011, A computer program for flow-log analysis of single holes (FLASH): Ground Water, v. 49, no. 6, p. 926-931, accessed January 23, 2020, at https://doi.org/10.1111/ j.1745-6584.2011.00798.x.

Deeds, N.E., Harding, J.J., Jones, T.L., Singh, A., Hamlin, S., and Reedy, R.C., 2015, Final conceptual model report for the High Plains aquifer system groundwater availability model: Texas Water Development Board, 600 p., accessed on June 26, 2018, at https://texashistory.unt.edu/ark:/67531/ metapth838867/.

Dlubac, K., Knight, R., Song, Y., Bachman, N., Grau, B., Cannia, J., and Williams, J., 2013, Use of NMR logging to obtain estimates of hydraulic conductivity in the High Plains aquifer, Nebraska, USA: Water Resources Research, v. 49, no. 4, p. 1871-1886. [Also available at https://doi.org/ 10.1002/wrcr.20151.]

Driscoll, F.G., 1986, Groundwater and wells: Johnson Division, St. Paul, Minn., 1089 p.

Dubrovsky, N.M., Burow, K.R., Clark, G.M., Gronberg, J.M., Hamilton, P.A., Hitt, K.J., Mueller, D.K., Munn, M.D., Nolan, B.T., Puckett, L.J., Rupert, M.G., Short, T.M., Spahr, N.E., Sprague, L.A., and Wilber, W.G., 2010, The quality of our Nation's waters - Nutrients in the Nation's streams and groundwater, 1992-2004: U.S. Geological Survey Circular 1350, 174 p. [Also available at https://doi.org/10.3133/ cir1350.]

Dugan, J.T., McGrath, T.S., and Zelt, R.B., 1994, Waterlevel changes in the High Plains aquifer-Predevelopment to 1992: U.S. Geological Survey Water-Resources Investigations Report 94-4027, 56 p. [Also available at https://doi.org/10.3133/ofr20131054.]

Esri, 2016, ArcMAP - An overview of the Hydrology toolset: Redland, Calif., Esri, accessed January 8, 2020, at https:/ /desktop.arcgis.com/en/arcmap/10.3/tools/spatial-analysttoolbox/an-overview-of-the-hydrology-tools.htm. 
Fahlquist, L., 2003, Ground-water quality of the southern High Plains aquifer, Texas and New Mexico, 2001: U.S. Geological Survey Open-File Report 03-345, 59 p. [Also available at https://doi.org/10.3133/ofr03345.]

Fallin, J.A., 1989, Hydrogeology of lower Cretaceous strata under the Southern High Plains of Texas and New Mexico: Texas Water Development Board Report 314, 39 p.

Faure, G., 1986, Principles of isotope geology: New York, Wiley, 589 p.

Fenneman, N.M., 1931, Physiography of western United States: New York, McGraw-Hill Book Company, Inc., 534 p.

Fetter, C.W., 1988, Applied hydrogeology: New York, Macmillan, 592 p.

Fishman, M.J., ed., 1993, Methods of analysis by the U.S. Geological Survey National Water Quality LaboratoryDetermination of inorganic and organic constituents in water and fluvial sediments: U.S. Geological Survey OpenFile Report 93-125, 217 p. [Also available at https://doi.org/ 10.3133/ofr93125.]

Fishman, M.J., and Friedman, L.C., 1989, Methods for determination of inorganic substances in water and fluvial sediments: U.S. Geological Survey Techniques of WaterResources Investigations, book 5, chap. A1, 545 p. [Also available at https://doi.org/10.3133/twri05A1.]

Fontes, J., 1980, Environmental isotopes in groundwater hydrology, in Fritz, P., and Fontes, J., eds., Handbook of environmental isotope geochemistry, v. 1, The terrestrial environment: New York, Elsevier, p. 75-140.

Freeze, R.A., and Cherry, J.A., 1979, Groundwater: Englewood Cliffs, N.J., Prentice-Hall, 604 p.

Fritz, P., and Fontes, J.C., eds., 1980, Handbook of environmental isotope geochemistry, v. 1-The terrestrial environment: Amsterdam, Elsevier, 545 p.

Garbarino, J.R., 1999, Methods of analysis by the U.S. Geological Survey National Water Quality LaboratoryDetermination of dissolved arsenic, boron, lithium, selenium, strontium, thallium, and vanadium using inductively coupled plasma-mass spectrometry: U.S. Geological Survey Open-File Report 99-093, 31 p. [Also available at https://doi.org/10.3133/ofr9993.]

Garbarino, J.R., Kanagy, L.K., and Cree, M.E., 2006, Determination of elements in natural-water, biota, sediment and soil samples using collision/reaction cell inductively coupled plasma-mass spectrometry: U.S. Geological Survey Techniques and Methods, book 5, sec. B, chap. 1, 88 p. [Also available at https://doi.org/10.3133/tm5b1.]
Gat, J.R., and Gonfiantini, R., eds., 1981, Stable isotope hydrology-Deuterium and oxygen-18 in the water cycle: Vienna, International Atomic Energy Agency, Technical Report Series 210, 337 p.

Gaum, C.H., 1953, High Plains, or Llano Estacado, TexasNew Mexico, chap. 6 of The physical and economic foundation of natural resources-Volume 4, Subsurface facilities of water management and patterns of supply-Type area studies: Interior and Insular Affairs Committee, House of Representatives, United States Congress, p. 94-104.

Geonics Limited, 2006a, Products-TEM47: Mississauga, Ontario, Canada, Geonics Limited, accessed June 12, 2020 , at http://www.geonics.com/html/tem47.html.

Geonics Limited, 2006b, Products-TEM47: Mississauga, Ontario, Canada, Geonics Limited, accessed June 12, 2020, at http://www.geonics.com/html/tem57-mk2.html.

George, P.G., Mace, R.E., and Petrossian, R., 2011, Aquifers of Texas: Texas Water Development Board Report 380, $182 \mathrm{p}$.

Gurdak, J. J., McMahon, P.B., Dennehy, K., and Qi, S.L., 2009, Water quality in the High Plains aquifer, Colorado, Kansas, Nebraska, New Mexico, Oklahoma, South Dakota, Texas, and Wyoming, 1999-2004: U.S. Geological Survey Circular 1337, 64 p. [Also available at https://doi.org/ 10.3133/cir1337.]

Gustavson, T.C., 1996, Fluvial and eolian depositional systems, paleosols, and paleoclimate of the Late Cenozoic Ogallala and Blackwater Draw Formations: The University of Texas at Austin, Bureau of Economic Geology Report of Investigations No. 239, 62 p. [Also available at https:/ /www.beg.utexas.edu/publications/fluvial-and-eoliandepositional-systems-paleosols-and-paleoclimate-uppercenozoic.]

Gutentag, E.D., Heimes, F.J., Krothe, N.C., Luckey, R.R., Weeks, J.B., 1984, Geohydrology of the High Plains aquifer in parts of Colorado, Kansas, Nebraska, New Mexico, Oklahoma, South Dakota, Texas, and Wyoming: U.S. Geological Survey Professional Paper 1400-B, 63 p., accessed January 23, 2020, at https://doi.org/10.3133/pp1 400B.

Heath, R.C., 1983, Basic ground-water hydrology: U.S. Geological Survey Water-Supply Paper 2220, 86 p. [Also available at https://doi.org/10.3133/wsp2220.]

Helsel, D.R., Hirsch, R.M., Ryberg, K.R., Archfield, S.A., and Gilroy, E.J., 2020, Statistical methods in water resources: U.S. Geological Survey Techniques and Methods, book 4, chapter A3, 458 p. [Supersedes USGS Techniques of WaterResources Investigations, book 4, chapter A3, version 1.1.] [Also available at https://doi.org/10.3133/tm4a3.] 
Hem, J.D., 1985, Study and interpretation of the chemical characteristics of natural water ( $3 \mathrm{~d}$ ed.): U.S. Geological Survey Water-Supply Paper 2254, 263 p. [Also available at https://doi.org/10.3133/wsp2254.]

Hillel, Daniel, 2008, Soil in the environment, Chapter 7Soil-water dynamics: New York, Goddard Institute for Space Studies, Columbia University, p. 91-101, accessed March 27, 2020, at https://doi.org/10.1016/C2009-0-000415.

Hinkle, S.R., 1996, Age of ground water in basalt aquifers near Spring Creek National Fish Hatchery, Skamania County, Washington: U.S. Geological Survey WaterResources Investigations Report 95-4272, 26 p., accessed January 23, 2020, at https://doi.org/10.3133/wri954272.

Homer, C.G., Dewitz, J.A., Yang, L., Jin, S., Danielson, P., Xian, G., Coulston, J., Herold, N.D., Wickham, J.D., and Megown, K., 2015, Completion of the 2011 National Land Cover Database for the conterminous United StatesRepresenting a decade of land cover change information: Photogrammetric Engineering and Remote Sensing, v. 81, no. 5, p. 345-354, [Also available at https://www.ingentaco nnect.com/content/asprs/pers/2015/00000081/00000005/ art00002.]

Hull, R.B., Johnson, C.D., Stone, B.D., LeBlanc, D.R., McCobb, T.D., Phillips, S.N., Pappas, K.L., and Lane, J.W., 2019, Lithostratigraphic, geophysical, and hydrogeologic observations from a boring drilled to bedrock in glacial sediments near Nantucket sound in East Falmouth, Massachusetts: U.S. Geological Survey Scientific Investigations Report 2019-5042, 27 p., accessed January 23, 2020, at https://doi.org/10.3133/sir20195042.

Ingebritsen, S.E., and Sanford, W.E., 1999, Groundwater in geologic processes ( $2 \mathrm{~d}$ ed.): New York, Cambridge University Press, 341 p.

Interpex Limited, 1996, IX1D version 3 1D sounding inversion software: Golden, Colo., accessed on June 12, 2020, at http://www.interpex.com.

Jouzel, J., Koster, R.D., Suozzo, R.J., and Russell, G.L., 1994, Stable water isotope behavior during the last glacial maximum-A general circulation model analysis: Journal of Geophysical Research, 99 p., accessed January 14, 2020, at https://doi.org/10.1029/94JD01819.

Kadhim, F.S., Samsuri, A., and Kamal, A., 2013, 2013, A review in correlations between cementation factor and carbonate rock properties: Life Science Journal, v. 10, no. 4, p. 2451-2458.

Kalin, R.M., 2000, Radiocarbon dating of groundwater systems, in Cook, P.G., and Herczeg, A.L., eds., Chapter 4-Environmental tracers in subsurface hydrology: Boston, Kluwer Academic Publishers, p. 111-144.
Karlen, I., Olsson, I.U., Kallburg, P., and Kilici, S., 1964, Absolute determination of the activity of two ${ }^{14} \mathrm{C}$ dating standards: Arkiv Geofysik, v. 4, p. 465-471.

Kass, M.A., Bloss, B.R., Irons, T.P., Cannia, J.C., and Abraham, J.D., 2014, Magnetic resonance sounding data collected in the North Platte, Twin Platte, and South Platte Natural Resource Districts Western Nebraska, Fall 2012: U.S. Geological Survey Open-File Report 2014-1138, 16 p., accessed January 23, 2020, at https://doi.org/10.3133/ ofr20141138.

Kaufman, A., and Itskovich, G., 2017, Basic principles of induction logging - Electromagnetic methods in borehole geophysics: Amsterdam, Elsevier, 520 p. [Also available at https://doi.org/10.1016/C2014-0-01182-3.]

Kaufman, A.A., and Dashevsky, Y.A., 2003, Principles of induction logging 1st ed., v. 38: Amsterdam, Elsevier, 656 p.

Kendall, C., and McDonnell, J.J., eds., 1998, Isotope tracers in catchment hydrology: Amsterdam, Elsevier, 839 p.

Kenyon, W.E., Day, P.I., Straley, C., and Willemsen, J.F., 1988, A three-part study of NMR longitudinal relaxation properties of water saturated sandstones: SPE Formation Evaluation, v. 3, no. 03, p. 622-636.

Kenyon, W.E., Kleinberg, R., Straley, C., Gubelin, G., and Morriss, C., 1995, Nuclear magnetic resonance imagingTechnology for the 21st century: Oilfield Review, v. 7, no. 3, p. 19-33.

Keys, W.S., 1997, A practical guide to borehole geophysics in environmental investigations: New York, CRC-Lewis Publishers, $176 \mathrm{p}$.

Kirkham, M.B., 2014, Principles of soil and plant water relations ( $2 \mathrm{~d}$ ed.), Chapter 7-Water movement in saturated soil: Manhattan, Kans., Kansas State University, p. 87-101, accessed March 27, 2020, at https://doi.org/10.1016/C20130-12871-1.

Knowles, T., Nordstrom, P., and Klemt, W.B., 1984, Evaluating the ground-water resources of the High Plains of Texas: Texas Department of Water Resources Report 288, v. $1,178 \mathrm{p}$.

Kohlrenken, W., Boghici, R., and Jones, I., 2013, GAM Task 13-026-Total estimated recoverable storage for aquifers in groundwater management area 2: Austin, Tex., Texas Water Development Board, $26 \mathrm{p}$.

Koterba, M.T., Wilde, F.D., and Lapham, W.W., 1995, Groundwater data-collection protocols and procedures for the National Water-Quality Assessment ProgramCollection and documentation of water-quality samples and related data: U.S. Geological Survey Open-File Report 95-399, 113 p., accessed January 23, 2020, at https://doi.org/10.3133/ofr95399. 
Larkin, T.J., and Bomar, G.W., 1983, Climatic atlas of Texas: Texas Department of Water Resources, Limited Printing Report LP-192, 151 p.

Legchenko, A., Descloitres, M., Bost, A., Ruiz, L., Reddy, M., Girard, J.F., Sekhar, M., Mohan Kumar, M.S., and Braun, J.-J., 2006, Resolution of MRS applied to the characterization of hard-rock aquifers: Ground Water, v. 44, no. 4, p. 547-554. https://doi.org/10.1111/j.17456584.2006.00198.x.

Lemay, T.G., 2002, Carbon-14 dating of groundwater from selected wells in Quaternary and Quaternary-Tertiary sediments, Athabasca Oil Sands (in-situ) area, Alberta: Alberta Geological Survey, $21 \mathrm{p}$.

Libby, W.F., 1955, Radiocarbon dating (2nd ed.): Chicago, Ill., University of Chicago Press, $184 \mathrm{p}$.

Lindley, C.E., Stewart, J.T., and Sandstrom, M.W., 1996, Determination of low concentrations of acetochlor in water by automated solid-phase extraction and gas chromatography with mass selective detection: Journal of AOAC International, v. 79, no. 4, p. 962-966. [Also available at https://doi.org/10.1093/jaoac/79.4.962.]

Lindsey, B.D., Jurgens, B.C., and Belitz, K., 2019, Tritium as an indicator of modern, mixed, and premodern groundwater age: U.S. Geological Survey Scientific Investigations Report 2019-5090, 18 p. [Also available at https://doi.org/ 10.3133/sir20195090.]

Linsley, R.K., Kohler, M.A., and Paulhus, J.L.H., 1982, Hydrology for engineers 3rd ed.: New York, McGrawHill, 512 p.

Llano Estacado Underground Water Conservation District, 2020a, Llano Estacado Underground Water Conservation District-Management plan: Llano Estacado Underground Water Conservation District, accessed January 23, 2020, at http://www.llanoestacadouwcd.org/managementplan.html.

Llano Estacado Underground Water Conservation District, 2020b, Llano Estacado Underground Water Conservation District-Maps: Llano Estacado Underground Water Conservation District, accessed January 23, 2020, at http://www.llanoestacadouwcd.org/maps.html.

Lohman, S.W., 1979, Ground-water hydraulics: U.S. Geological Survey Professional Paper 708, 70 p. [Also available at https://doi.org/10.3133/pp708.]

Lucas, L.L., and Unterweger, M.P., 2000, Comprehensive review and critical evaluation of the half-life of tritium: Journal of Research of the National Institute of Standards and Technology, v. 105, no. 4, p. 541-549.
Lucius, J.E., Langer, W.H., and Ellefsen, K.J., 2007, An introduction to using surface geophysics to characterize sand and gravel deposits: U.S. Geological Survey Circular 1310, 33 p. [Also available at https://doi.org/10.3133/cir1310.]

Madsen, J.E., Sandstrom, M.W., and Zaugg, S.D., 2003, Methods of analysis by the U.S. Geological Survey National Water Quality Laboratory-A method supplement for the determination of fipronil and degradates in water by gas chromatography/mass spectrometry: U.S. Geological Survey Open-File Report 02-462, 11 p. [Also available at https://doi.org/10.3133/ofr02462.]

Martin, J.D., Stone, W.W., Wydoski, D.S., and Sandstrom, M.W., 2009, Adjustment of pesticide concentrations for temporal changes in analytical recovery, 1992-2006: U.S. Geological Survey Scientific Investigations Report 2009-5189, 23 p. plus app. [Also available at https://doi.org/10.3133/sir20095189.]

McGowen, J.H., Granata, G.E., and Seni, S.J., 1979, Depositional framework of the lower Dockum Group (Triassic), Texas Panhandle: The University of Texas at Austin, Bureau of Economic Geology Report of Investigations, no. 97, $60 \mathrm{p}$.

McGuire, V.L., 2017, Water-level and recoverable water in storage changes, High Plains aquifer, predevelopment to 2015 and 2013-15: U.S. Geological Survey Scientific Investigations Report 2017-5040, 14 p., accessed January 23, 2020, at https://doi.org/10.3133/sir20175040.

McMahon, P.B., Böhlke, J.K., and Lehman, T.M., 2004, Vertical gradients in water chemistry and age in the southern High Plains aquifer, Texas, 2002: U.S. Geological Survey Scientific Investigations Report 2004-5053, 53 p. [Also available at https://doi.org/10.3133/sir20045053.]

McNutt, R.H., Frape, S.K., Fritz, P., Jones, M.G., and MacDonald, I.M., 1990, The ${ }^{87} \mathrm{Sr} / 86 \mathrm{Sr}$ values of Canadian Shield brines and fracture minerals with applications to groundwater mixing, fracture history, and geochronology: Geochimica et Cosmochimica Acta, v. 54, no. 1, p. 205-215.

Menheer, M.A., and Brigham, M.E., 1997, Ground-water sampling methods and quality-control data for the Red River of the North basin, Minnesota, North Dakota, and South Dakota, 1993-95: U.S. Geological Survey Water-Resources Investigations Report 96-4317, 40 p., accessed January 23, 2020, at https://doi.org/10.3133/wri964317.

Michel, R.L., Jurgens, B.C., and Young, M.B., 2018, Tritium deposition in precipitation in the United States, 1953-2012: U.S. Geological Survey Scientific Investigations Report 2018-5086, 11 p., accessed January 23, 2020, at https://doi.org/10.3133/sir20185086. 
Motzer, W.E., 2008, Age dating groundwater: Alameda, Calif., Todd Engineers, 4 p.

Mount Sopris Instruments, 2020, Downhole probes, Denver Colo., Mount Sopris Instruments, accessed January 23, 2020, at https://mountsopris.com/products/ downhole-probes/.

Mueller, D.K., Martin, J.D., and Lopes, T.J., 1997, Qualitycontrol design for surface-water sampling in the National Water-Quality Assessment Program: U.S. Geological Survey Open-File Report 97-223, 17 p., accessed January 23, 2020, at https://doi.org/10.3133/ofr97223.

Mueller, D.K., Schertz, T.L., Martin, J.D., and Sandstrom, M.W., 2015, Design, analysis, and interpretation of field quality-control data for water-sampling projects: U.S. Geological Survey Techniques and Methods, book 4, chap. C4, 54 p., accessed January 23, 2020, at https://doi.org/ $10.3133 / \mathrm{tm} 4 \mathrm{C} 4$.

Musgrove, M.L., and Banner, J.L., 1993, Regional groundwater mixing and the origin of saline fluids-Midcontinent, United States: Science, v. 259, no. 5103, p. 1877-1882.

Musgrove, M.L., Fahlquist, L., Houston, N.A., Lindgren, R.J., and Ging, P.B., 2010, Geochemical evolution processes and water-quality observations based on results of the National Water-Quality Assessment Program in the San Antonio segment of the Edwards aquifer, 1996-2006: U.S. Geological Survey Scientific Investigations Report 2010-5129, 93 p. [Also available at https://doi.org/10.3133/sir20105129.]

Nathenson, M., and Guffanti, M., 1988, Geothermal gradients in the conterminous United States: Journal of Geophysical Research, v. 93, no. B6, no. B6, p. 6437-6450.

National Oceanic and Atmospheric Administration, 2010, National Climatic Data Center-Monthly normal: National Oceanic and Atmospheric Administration, accessed January 23, 2020, at https://www.ncdc.noaa.gov/cdo-web/ datatools.

National Oceanic and Atmospheric Administration, 2020, National Center for Environmental InformationMonthly Summary Observations: National Oceanic and Atmospheric Administration, accessed January 18, 2020, at https://gis.ncdc.noaa.gov/maps/ncei/summaries/monthly.

Nishikawa, T., Izbicki, J.A., Hevesi, J.A., Stamos, C.L., and Martin, P., 2004, Evaluation of geohydrologic framework, recharge estimates, and ground-water flow of the Joshua Tree area, San Bernardino County, California: U.S. Geological Survey Scientific Investigations Report 2004-5267, 115 p. [Also available at https://doi.org/ 10.3133/sir20045267.]
Oden, J.H., Brown, D.W., and Oden, T.D., 2011, Groundwater quality of the Gulf Coast aquifer system, Houston, Texas, 2010: U.S. Geological Survey Data Series 598, 64 p. [Also available at https://doi.org/10.3133/ds598.]

Oden, T.D., and Truini, M., 2013, Estimated rates of groundwater recharge to the Chicot, Evangeline, and Jasper aquifers by using environmental tracers in Montgomery and adjacent counties, Texas, 2008 and 2011: U.S. Geological Survey Scientific Investigations Report 2013-5024, 50 p. [Also available at https://doi.org/10.3133/sir20135024.]

Olsson, I.U., and Klasson, M., 1970, Uppsala radiocarbon measurements X: Radiocarbon, v. 12, no. 1, p. 281-284

Östlund, H.G., and Werner, E., 1962, Electrolytic enrichment of tritium and deuterium for natural tritium measurementsTritium in the physical and biological sciences v. 1: Vienna, Austria, International Atomic Energy Agency, p. 96-104.

Patton, C.J., and Kryskalla, J.R., 2003, Methods of analysis by the U.S. Geological Survey National Water Quality Laboratory-Evaluation of alkaline persulfate digestion as an alternative to kjeldahl digestion for determination of total and dissolved nitrogen and phosphorus in water: U.S. Geological Survey Water-Resources Investigations Report 03-4174, 33 p. [Also available at https://doi.org/10.3133/ wri034174.]

Payne, J.D., Teeple, A.P., and Thomas, J.V., 2020, Compilation of time-domain electromagnetic surface geophysical soundings, historical borehole characteristics, water level, water quality and hydraulic properties data throughout Gaines, Yoakum, and Terry Counties in Texas, 1929-2019: U.S. Geological Survey data release, https://doi.org/10.5066/ P9N3WKQ5.

Peckham, D.S., and Ashworth, J.B., 1993, The High Plains aquifer system of Texas, 1980 to 1990 overview and projections: Austin, Tex., Texas Water Development Board Report 341, 37 p. [Also available at https://www.twdb.texas.gov/ publications/reports/numbered_reports/doc/R341/R341.pdf? $\mathrm{d}=48005.53499997477$.]

Phillips, F.M., and Castro, M.C., 2003, Groundwater dating and residence time measurements, in Treatise on Geochemistry: Surface and Ground Water, Weathering, and Soils, v. 5, p. 451-497.

Piper, A.M., 1944, A graphic procedure in the geochemical interpretation of water analyses: Transactions - American Geophysical Union, v. 25, no. 6, p. 914-923.

Pischel, E.M., and Gannett, M.W., 2015, Effects of groundwater pumping on agricultural drains in the Tule Lake subbasin, Oregon and California: U.S. Geological Survey Scientific Investigations Report 2015-5087, 44 p., accessed August 4, 2020, at https://doi.org/10.3133/sir20155087. 
Plata, J.L., and Rubio, F.M., 2008, The use of MRS in the determination of hydraulic transmissivity-The case of alluvial aquifers: Journal of Applied Geophysics, v. 66, no. 3-4, p. 128-139.

Plummer, L.N., Prestemon, E.C., and Parkhurst, D.L., 1994, An interactive code (NETPATH) for modeling net geochemical reactions along a flow path version 2.0: U.S. Geological Survey Water-Resources Investigation Report 94-4169, 133 p. [Also available at https://doi.org/10.3133/ wri944169.]

Raymond, P.A., and Bauer, J.E., 2001, Use of ${ }^{14} \mathrm{C}$ and ${ }^{13} \mathrm{C}$ natural abundances for evaluating riverine, estuarine, and coastal DOC and POC sources and cycling-A review and synthesis: Organic Geochemistry, v. 32, no. 4, p. 469-486.

Rettman, P.L., and Leggat, E.R., 1966, Ground-water resources of Gaines County, Texas: Austin, Tex., Texas Water Development Board Report 15, 183 p.

Révész, K., and Coplen, T.B., 2008a, Determination of the $\delta\left({ }^{2} \mathrm{H} /{ }^{1} \mathrm{H}\right)$ of water-RSIL lab code 1574 , chap. C1 of Révész, K., and Coplen, T.B., eds., Methods of the Reston Stable Isotope Laboratory: U.S. Geological Survey Techniques and Methods, book 10, chap. C1, 27 p. [Also available at https://doi.org/10.3133/tm10C1.]

Révész, K., and Coplen, T.B., 2008b, Determination of the $\delta(18 \mathrm{O} / 16 \mathrm{O})$, of water: RSIL lab code 489 , chap. C2 of Révész, K., and Coplen, T.B., eds., Methods of the Reston Stable Isotope Laboratory: U.S. Geological Survey Techniques and Methods, book 10, chap. C2, 28 p. [Also available at https://doi.org/10.3133/tm10C2.]

Roberts, M.L., Burton, J.R., Elder, K.L., Longworth, B.E., McIntyre, C.P., von Reden, K.F., Han, B.X., Rosenheim, B.E., Jenkins, W.J., Galutschek, E., and McNichol, A.P., 2010, A high-performance ${ }^{14} \mathrm{C}$ accelerator mass spectrometry system: Radiocarbon, v. 52, no. 2, p. 228-235.

Ryder, P.D., 1996, Ground water atlas of the United StatesSegment 4, Oklahoma: Texas: U.S. Geological Survey Hydrologic Investigations Atlas, v. 730-E, accessed January 23, 2020, at https://doi.org/10.3133/ha730E.

Sandstrom, M.W., Stroppel, M.E., Foreman, W.T., and Schroeder, M.P., 2001, Methods of analysis by the U.S. Geological Survey National Water Quality LaboratoryDetermination of moderate-use pesticides and selected degradates in water by $\mathrm{C}-18$ solid-phase extraction and gas chromatography/mass spectrometry: U.S. Geological Survey Water-Resources Investigations Report 01-4098, 70 p. [Also available at https://doi.org/10.3133/ wri20014098.]
Sandy Land Underground Water Conservation District, 2020, Sandy Land Underground Water Conservation District-Management plan: Sandy Land Underground Water Conservation District, accessed January 23, 2020, at https://www.sandylandwater.com/wp-content/uploads/2019/ 08/2019-SL-Management-Plan-with-Appendices.pdf.

Scanlon, B.R., Nicot, J.P., Reedy, R., Tachovsky, J.A., Nance, S.H., Smyth, R.C., Keese, K., Ashburn, R.E., and Christian, L., 2005, Evaluation of arsenic contamination in Texas: The University of Texas at Austin, Bureau of Economic Geology, final report prepared for Texas Commission on Environmental Quality, under contract no. UT-08-5-70828, 177 p., accessed on March 31, 2020, at https://www.beg.u texas.edu/files/content/beg/research/water/Scanlon_As r2005.pdf.

Seequent, 2020a, Geosoft Technical Workshop_-Topics in gridding: Broomfield, Calif., Seequent, accessed October 27, 2020, at https://files.seequent.com/MySeequent/ technical-papers/topicsingriddingworkshop.pdf.

Seequent, 2020b, Regional trend removal: Broomfield, Calif., Seequent, accessed October 27, 2020, at https://my.see quent.com/support/help/oasismontaj-gxs-content_gxhelp_ g_gridstch_1r.htm?page $=0 \&$ types $=$ All\&product $=$ $1 \&$ keyword $=$ technical $\% 20$ papers $\% 20$ trend\&name= Regional\%20Trend\%20Removal.

Seni, S.J., 1980, Sand-body geometry and depositional systems, Ogallala Formation, Texas: The University of Texas at Austin; Bureau of Economic Geology Report of Investigations No. 105, 36 p.

Shelton, L.R., 1994, Field guide for collecting and processing stream-water samples for the National Water-Quality Assessment Program: U.S. Geological Survey OpenFile Report 94-455, 42 p., accessed January 23, 2020, at https://doi.org/10.3133/ofr94455.

Shoda, M.E., Nowell, L.H., Stone, W.W., Sandstrom, M.W., and Bexfield, L.M., 2018, Data analysis considerations for pesticides determined by National Water Quality Laboratory schedule 2437: U.S. Geological Survey Scientific Investigations Report 2018-5007, 458 p., accessed January 23, 2020, at https://doi.org/10.3133/sir20185007.

South Plains Underground Water Conservation District, 2020a, South Plains Underground Water Conservation District-Management plan: South Plains Underground Water Conservation District, accessed January 23, 2020, at http://spuwcd.org/wp-content/uploads/2018/12/2019_MgtPlan_Final.pdf.

South Plains Underground Water Conservation District, 2020b, South Plains Underground Water Conservation District-Maps: South Plains Underground Water Conservation District, accessed January 23, 2020, at http://spuwcd.org/maps/. 
Stallman, R.W., 1971, Aquifer-test design, observation and data analysis: Techniques of Water-Resources Investigations of the U.S. Geological Survey, book 3, chap. B1, 26 p., accessed October 27, 2020, at https://doi.org/10.3133/twri 03B1.

Stanton, J.S., and Fahlquist, L., 2006, Ground-water quality beneath irrigated cropland of the northern and southern High Plains aquifer, Nebraska and Texas, 2003-04: U.S. Geological Survey Scientific Investigations Report 2006-5196, 39 p., accessed April 2, 2020, at https://doi.org/ 10.3133/sir20075143.

Stovall, J.N., 2001, Groundwater modeling for the southern High Plains: Lubbock, Tex., Texas Tech University Water Resources Center, 298 p. [Also available at https://tu-ir.tdl.org/ttu-ir/bitstream/handle/2346/8890/ 31295016557992.pdf? sequence $=1$.]

Straley, C., Rossini, D., Vinegar, H.J., Tutunjian, P.N., and Morriss, C.E., 1997, Core analysis by low-field NMR: The Log Analyst, v. 38, no. 2, p. 84-94.

Stuiver, M., 1980, Workshop on ${ }^{14} \mathrm{C}$ data reporting: Radiocarbon, v. 22, no. 3, p. 964-966.

Stuiver, M., and Polach, H.A., 1977, Reporting of ${ }^{14} \mathrm{C}$ data: Radiocarbon, v. 19, no. 3, p. 355-363.

Teeple, A.P., 2017, Geophysics- and geochemistry-based assessment of the geochemical characteristics and groundwater-flow system of the U.S. part of the Mesilla Basin/Conejos-Médanos aquifer system in Doña Ana County, New Mexico, and El Paso County, Texas, 2010-12: U.S. Geological Survey Scientific Investigations Report 2017-5028, 183 p., accessed January 23, 2020, at https://doi.org/10.3133/sir20175028.

Teeple, A.P., Thomas, J.V., Payne, J.D., Ikard, S.J., Wallace, D.S., Houston, N.A., and Kraske, K.A., 2018, Data used to assess the hydrogeologic framework with emphasis on the Ogallala and Edwards-Trinity aquifers, in and near Gaines, Terry, and Yoakum Counties, Texas, 2018: U.S. Geological Survey data release, accessed January 23, 2020, at https://doi.org/10.5066/F7F47NFC.

Texas Water Development Board, 2017, Historical water use estimates-Water use summary estimates-2017: Texas Water Development Board, accessed on June 4, 2020, at https://www.twdb.texas.gov/waterplanning/waterusesurvey/ estimates/index.asp.

Texas Water Development Board, 2020a, Minor aquifersEdwards-Trinity (High Plains) aquifer: Texas Water Development Board, accessed January 7, 2020, at http:/ /www.twdb.texas.gov/groundwater/aquifer/minors/edwardstrinity-high-plains.asp.
Texas Water Development Board, 2020b, Major aquifersOgallala aquifer: Texas Water Development Board, accessed January 8, 2020, at http://www.twdb.texas.gov/ groundwater/aquifer/majors/ogallala.asp.

Texas Water Development Board, 2020c, Groundwater database report: Texas Water Development Board, accessed January 23, 2020, at http://www.twdb.texas.gov/ groundwater/data/gwdbrpt.asp.

Texas Water Development Board, 2020d, Submitted drillers reports (SDR) database: Texas Water Development Board, accessed January 23, 2020, at http://www.twdb.texas.gov/ groundwater/data/drillersdb.asp.

Texas Water Development Board, 2020e, BRACS database: Texas Water Development Board, accessed January 23, 2020, at http://www.twdb.texas.gov/innovativewater/bracs/ database.asp.

Thatcher, L.L., Janzer, V.J., and Edwards, K.W., 1977, Methods for determination of radioactive substances in water and fluvial sediments: U.S. Geological Survey Techniques of Water-Resources Investigations, book 5, chap. A5, 95 p. [Also available at https://doi.org/10.3133/ twri05A5.]

Thomas, J.V., Stanton, G.P., and Lambert, R.B., 2012, Borehole geophysical, fluid, and hydraulic properties within and surrounding the freshwater/saline-water transition zone, San Antonio segment of the Edwards aquifer, southcentral Texas, 2010-11: U.S. Geological Survey Scientific Investigations Report 2012-5285, 65 p., 3 apps. [Also available at https://doi.org/10.3133/sir20125285.]

Thomas, J.V., Teeple, A.P., Payne, J.D., and Ikard, S., 2016, Changes between early development (1930-60) and recent (2005-15) groundwater-level altitudes and dissolved-solids and nitrate concentrations in and near Gaines, Terry, and Yoakum Counties, Texas: U.S. Geological Survey Scientific Investigations Map 3355, 2 sheets, pamphlet, accessed January 23, 2020, at https://doi.org/10.3133/sim3355.

Thomas, J.V., Teeple, A.P., Payne, J.D., and Ikard, S.J., 2019, A refined hydrogeologic framework model for Gaines, Terry, and Yoakum Counties, Texas: Texas Water Resources Institute, Texas Water Journal, v. 10, no. 1, p. 1-21.

Timur, A., 1969, Pulsed nuclear magnetic resonance studies of porosity, mobile fluid and permeability of sandstones: Journal of Petroleum Technology, v. 21, no. 06, p. 775-786.

Uliana, M.M., Banner, J.L., and Sharp, J.M., Jr., 2007, Regional groundwater flow paths in Trans-Pecos, Texas inferred from oxygen, hydrogen, and strontium isotopes: Journal of Hydrology (Amsterdam), v. 334, no. 3-4, p. 334-346. 
U.S. Census Bureau, 2020, State and county quick factsPopulation estimates, July 1, 2018: U.S. Census Bureau, accessed January 8, 2020, at https://www.census.gov/ quickfacts/fact/table/US/PST045219.

U.S. Department of Agriculture, 2019, 2017 Census of Agriculture: United States Summary and State Data, v. 1, Geographic Series Part 51, AC-17-A-51, accessed on June 4, 2020, at https://www.nass.usda.gov/Publications/ AgCensus/2017/.

U.S. Environmental Protection Agency, 2020, Drinking water contaminants standards and regulations: U.S. Environmental Protection Agency, accessed January 23, 2020, at https://water.epa.gov/drink/contaminants/index.cfm.

U.S. Geological Survey, 2012a, The Reston Groundwater Dating Laboratory: U.S. Geological Survey, accessed January 23, 2020, at https://water.usgs.gov/lab/.

U.S. Geological Survey, 2012b, Reston Stable Isotope Laboratory (RSIL): U.S. Geological Survey, accessed January 23, 2020, at https://isotopes.usgs.gov/.

U.S. Geological Survey, 2017, 3DEP products and services: The National Map, 3D Elevation Program Web page, accessed January 23, 2020, at https://www.usgs.gov/corescience-systems/ngp/3dep/about-3dep-products-services.

U.S. Geological Survey, 2020a, GeoLog Locator: U.S. Geological Survey, accessed January 23, 2020, at https://webapps.usgs.gov/GeoLogLocator/.

U.S. Geological Survey, 2020b, U.S. Geological Survey water data for Texas: National Water Information System (NWIS) database, accessed January 23, 2020, at https://doi.org/ 10.5066/F7P55KJN.

U.S. Geological Survey, 2020c, USGS health-based screening levels: U.S. Geological Survey, accessed January 13, 2020, at https://water.usgs.gov/water-resources/hbsl.

U.S. Geological Survey, variously dated, National field manual for the collection of water-quality data: U.S. Geological Survey Techniques of Water-Resources Investigations, book 9, chaps. A1-A9. [Also available at https://doi.org/10.3133/ twri09A.]

Vignesh, A., Ramanujam, N., Kumar, B.S., and Rasool, Q.A., 2015, Application of time domain electromagnetic (Tdem) methods for mapping of salt fresh water intrusions and evaluate the porosity in Carbyn's Cove, Wandoor and Khurumedhera Beaches in South Andaman: Journal of Coastal Zone Management, v. 18, no. 4, 5 p. [Also available at https://doi.org/10.4172/2473-3350.1000413.]

Vista Clara Inc., 2020, Dart, Javelin, and Javelin WirelineWell logging: Vista Clara Inc., accessed January 16, 2020, at https://www.vista-clara.com/borehole-logging-solutions/.
Walbrecker, J.O., Hertrich, M., and Green, A.G., 2009, Accounting for relaxation processes during the pulse in surface NMR data: Geophysics, v. 74, no. 6, p. G27-G34.

Walsh, D., Turner, P., Grunewald, E., Zhang, H., Butler, J.J., Reboulet, E., Knobbe, S., Christy, T., Lane, J.W., Johnson, C.D., Munday, T., and Fitzpatrick, A., 2013, A smalldiameter NMR logging tool for groundwater investigations: Ground Water, v. 51, p. 914-926. [Also available at https://doi.org/10.1111/gwat.12024.]

Waxman, M.H., and Smits, L.J.M., 1968, Electrical conductivities in oil bearing shaly sands: Society of Petroleum Engineers Journal, v. 8, no. 02, p. 107-122. [Also available at https://doi.org/10.2118/1863-A.]

Weeks, J.B., Gutentag, E.D., Heimes, F.J., and Luckey, R.R., 1988, Summary of the High Plains Regional AquiferSystem Analysis in parts of Colorado, Kansas, Nebraska, New Mexico, Oklahoma, South Dakota, Texas, and Wyoming: U.S. Geological Survey Professional Paper 1400-A, p. A1-A30. [Also available at https://doi.org/ 10.3133/pp1400A.]

Weichman, P.B., Lavely, E.M., and Ritzwoller, M.H., 2000, Theory of surface nuclear magnetic resonance with applications to geophysical imaging problems: Physical Review E, v. 62, no. 1, p. 1290-1312. [Also available at https://doi.org/ 10.1103/PhysRevE.62.1290.]

Wermund, E.G., 1996, Physiographic map of Texas: The University of Texas at Austin, Bureau of Economic Geology Map SM0005.

Wilde, F.D., ed., 2004, Cleaning of equipment for water sampling (ver. 2.0): U.S. Geological Survey Techniques of Water-Resources Investigations, book 9, chap. A3, accessed January 23, 2020, at https://doi.org/10.3133/twri09A3.

Wilde, F.D., Radtke, D.B., Gibs, J., and Iwatsubo, R.T., eds., 2004 with updates through 2009, Processing of water samples (ver. 2.2): U.S. Geological Survey Techniques of Water-Resources Investigations, book 9, chap. A5, April 2004, accessed January 23, 2020, at https://doi.org/ 10.3133/twri09A3.

Winslow, A.G., and Kister, L.R., 1956, Saline-water resources of Texas: U.S. Geological Survey Water-Supply Paper 1365, 105 p. [Also available at https://doi.org/10.3133/wsp1365.]

Witcher, J.C., King, J.P., Hawley, J.W., Kennedy, J.F., Williams, J., Cleary, M., and Bothern, L.R., 2004, Sources of salinity in the Rio Grande and Mesilla Basin groundwater: New Mexico Water Resources Research Institute Technical Completion Report no. 330, 184 p. 
Woods Hole Oceanographic Institution, 2020, NOSAMS, National Ocean Sciences Accelerator Mass Spectrometry Facility - Radiocarbon data and calculations: Woods Hole Oceanographic Institution, accessed January 23, 2020, at https://www.whoi.edu/nosams/page.do?pid=40146.

Zaugg, S.D., Sandstrom, M.W., Smith, S.G., and Fehlberg, K.M., 1995, Methods of analysis by the U.S. Geological Survey National Water Quality Laboratory-Determination of pesticides in water by $\mathrm{C}-18$ solid-phase extraction and capillary-column gas chromatography/mass spectrometry with selected-ion monitoring: U.S. Geological Survey Open-File Report 95-181, 60 p., accessed January 14, 2021, at https://doi.org/10.3133/ofr95181.
Zohdy, A.A.R., Eaton, G.P., and Mabey, D.R., 1974, Application of surface geophysics to ground-water investigations: U.S. Geological Survey Techniques of WaterResources Investigations, book 2, chap. D1, 116 p. [Also available at https://doi.org/10.3133/twri02D1.] 
For more information about this publication, contact Director, Oklahoma-Texas Water Science Center U.S. Geological Survey 1505 Ferguson Lane Austin, TX 78754-4501 otpublicinfo@usgs.gov or visit https://www.usgs.gov/centers/ot-water

Publishing support provided by the Lafayette and West Trenton Publishing Service Centers 

